\title{
Phylogenetic study of the genera of Trichopterygini from Austral South America (Lepidoptera: Geometridae): a new classification
}

\section{Estudio filogenético de los géneros de Trichopterygini de Sudamérica Austral (Lepidoptera: Geometridae): una nueva clasificación}

\author{
Luis E. Parra ${ }^{1}$, Héctor A. Vargas ${ }^{2}$, María-José Sanzana ${ }^{1}$ \& Cristián E. Hernández ${ }^{1}$ \\ 1Departamento de Zoología, Facultad de Ciencias Naturales y Oceanográficas, Universidad de Concepción, Casilla 160-C, \\ Concepción, CHILE. e-mail: luparra@udec.cl \\ 2Departamento de Recursos Ambientales, Facultad de Ciencias Agronómicas, Universidad de Tarapacá, Casilla 6-D, Arica, \\ Chile. e-mail: havargas@uta.cl
}

\begin{abstract}
Phylogenetic study of the genera of South American Austral Trichopterygini (Lepidoptera: Geometridae, Larentiinae): a new classification. In this work, we evaluate the taxonomy of the Trichopterygini in Chile based on a phylogenetic analysis of the morphological attributes. In our analysis, we used Tatosoma and Sauris as outgroups. Two approaches were used to evaluate phylogenetic relationships: 1) parsimony criterion, and 2) Bayesian inference. Parsimony analysis was conducted in PAUP software, and Bayesian analysis with Markov chain Monte Carlo using the BayesPhylogenies software. Our results based on the phylogenetic hypothesis suggest a new taxonomic order for Trichopterygini of the Andean Region of Southern South America. The valid genera are: Arrayanaria Parra, Butleriana Parra, Danielaparra Kemal \& Kocak, Fueguina Parra, Hoplosauris Butler, Lagynopteryx Berg, Llampidken Parra \& Santos-Salas, Pachrophylla Blanchard, Parapachrophylla Parra, Rindgenaria Parra, Tomopteryx Philippi, Triptila Warren, Triptiloides Parra \& Santos-Salas, Warrenaria Parra. The main changes with respect to the previous taxonomic order are: 1) the genus Lagynopteryx Berg is subordinated under the Trichopterygini; 2) Toxopaltes Warren is a junior synonym of Lagynopteryx; 3) Hoplosauris moesta is transferred to the genus Llampidken; 4) Llampidken valdiviana is a junior synonym of L. moesta; 5) Oparabia arenosa is newly combined with the genus Arrayanaria; 6) Danielaparra viridis is a junior synonym of $D$. fragmentata; 7) Lobophora imbricaria is newly combined with the genus Danielaparra; 8) Triptiloides fasciata is a junior synonym of T. randallae; and 9) Parapachrophylla michelleae Parra n. sp. is described. Andean Region species are more closely related to the genus Tatosoma from New Zealand, the synapomorphies that demonstrate this are: swollen metaepimeron and hypertrophy of the second abdominal segment. A checklist of the genera and species of the tribe in the region, and the figures of adults and genitalia of some species are included.
\end{abstract}

KeYwords: Larentiinae, Lagynopteryx botulata (Felder \& Rogenhofer), Parapachrophylla michelleae Parra n. sp., Taxonomy, Distribution, Phylogeny, Chile, Argentina.

\footnotetext{
RESUMEN

En este trabajo se evalúa la taxonomía de los Trichopterygini de Chile a partir de un análisis filogenético de los atributos morfológicos. En nuestro análisis, hemos utilizado Tatosoma y Sauris como grupos externos. Se utilizaron dos enfoques para evaluar las relaciones filogenéticas: 1) criterio de parsimonia, y 2) inferencia bayesiana. El análisis de parsimonia se realizó a través del programa PAUP y el análisis bayesiano con cadenas de Markov y Monte Carlo a través del programa BayesPhylogenies. Nuestros resultados basados en la hipótesis filogenética sugieren un nuevo orden taxonómico para Trichopterygini de la Región Andina del Sur de Sudamérica. Los géneros válidos son: Arrayanaria Parra, Butleriana Parra, Danielaparra Kemal \& Kocak, Fueguina Parra, Hoplosauris Butler, Lagynopteryx Berg, Llampidken Parra \& Santos-Salas, Pachrophylla Blanchard, Parapachrophylla Parra, Rindgenaria Parra \& Santos-Salas, Tomopteryx Philippi, Triptila Warren y Warrenaria Parra. Los principales cambios con respecto al orden taxonómico anterior son: 1) el género Lagynopteryx Berg se incorpora a Trichopterygini; 2) Toxopaltes Warren es el sinónimo junior de Lagynopteryx; 3) Hoplosauris moesta se incorpora al género Llampidken; 4) Llampidken valdiviana es el sinónimo junior de L. Moesta; 5) Oparabia arenosa es incorporada al género Arrayanaria; 6) Danielaparra viridis es el sinónimo junior de D. fragmentata; 7) Lobophora imbricaria es incorporada al género Danielaparra; Triptiloides fasciata es el sinónimo junior de T. randallae; y 9) Parapachrophylla michelleae Parra n. sp. es descrita. Las especies de la Región Andina están más cerca del Tatosoma
} 
Trichopterygini from Chile and Argentina: PARRA L., ET AL.

de Nueva Zelanda, las sinapomorfias que demuestran esto son: el metaepimeron hinchado y la hipertrofia del segundo segmento abdominal. Se incluye un catálogo de los géneros y especies de la tribu en la región, y fotografías de adultos y armaduras genitales de algunas especies.

Palabras clave: Larentiinae, Lagynopteryx botulata (Felder \& Rogenhofer), Parapachrophylla michelleae Parra n. sp., Taxonomía, Distribución, Filogenia, Chile; Argentina.

\section{INTRODUCTION}

Geometridae are one of the most species-rich groups of Lepidoptera, currently it is found divided into seven subfamilies, with around 23,000 described species. Larentiinae, one of the most abundant subfamilies of the group, are found worldwide, even though they are more diverse in temperate regions and at high altitudes in the tropics. Larentiinae were divided into six subfamily groups by Warren (1894). However, the first division of Larentiinae into tribes was suggested by Forbes (1948), dividing the species into nine tribes on his list of North American species, and basing his classification on two characteristics in adults: chaetosemata and gena. Based on larvae, McGuffin (1958) revised the subfamily classification and presented keys for the tribes' genera. Herbulot $(1961,1962)$ proposed fourteen Larentiinae tribes. Patrocka (1994, 1995), working with pupae, in their Larentiinae phylogeny of Central Europe highlighted the incorrect placement of Lythriini in Herbulot (1961-1962) and Leraut's (1980) classification.

In Warren's (1894) classification of Larentiinae, Trichopterygini was grouped into those genera which have a lobe on the male's hindwings. Prout (1912) classified this group as a tribe, designated Trichopteryx (Hübner, 1816, $1825)$ as the genus type. Pierce (1914) named this tribe, Lobophorini, of which the genus type is Lobophora (Curtis). In his study, Forbes (1948) included six North American genera within Lobophorini. Dugdale (1980) made a revision of the Australian Trichopterygini, in which he mentioned the presence of three genera, Episteria, Sauris, and Tympanota and in addition, gave a brief synopsis of the group in the rest of the world. Dugdale established that the Neotropical species are more related to the New Zealand Tatosoma than the Australian genera. The treatment of Trichopterygini as a valid tribe was followed by numerous authors, among others Holloway (1997), Viidalepp (2011), and Hausmann \& Viidalepp (2012). Several studies have incorporated the tribe into the phylogenetic analyzes of Larentiinae. In all, Trichopterygini appears as a monophyletic group but with discrepancies regarding their phylogenetic position (Viidalepp 2006, Yamamoto \& Sota 2007, Õunap et al. 2008, Strutzenberger et al. 2010, Sihvonen et al. 2011, and Õunap et al. 2016).

Parra (1991), Parra and Santos-Salas (1992a-b), and Parra (1996) made a revision of the few genera mentioned for Chile, which were broken up into various taxa, constituting a group of 12 genera and 26 species. However, despite these recent revisions, until now there does not exist a phylogenetic analysis based on morphological characteristics of the type species of the different genera, which shows that the taxonomic situation of the genera in the South of South America could create many problems to solve. In this study, apart from the highlighted phylogenetic analysis, a new taxonomic order of the genera and species of the tribe is proposed, that includes the incorporation and reevaluation of genera, plus new synonyms and combinations for the previously used names.

\section{MATERIAL AND METHODS}

Material deposited in the Museo Nacional de Historia Natural, Santiago (MNHNS), Museo de Zoología de la Universidad de Concepción, Concepción (UCCC-MZUC), The Natural History Museum, Londres, UK (BMNH), Instituto Miguel Lillo, San Miguel de Tucumán, Argentina (IML) was revised, as were specimens collected from different Chilean sites. Some species were dissected to obtain the genitalia of males and females. 401 adults were reviewed (see appendix 1). For the nomenclature of the genital structure Klots (1970) was followed and Scoble (1995) for external characters.

Based on the morphology of the Trichopterygini group, two different phylogenetic focuses were used to evaluate the relationship between the components of their taxa: (1) optimization criteria of the maximum parsimony (MP), and (2) methods based on Bayesian inference. In both phylogenetic analyses, we used Sauris and Tatosoma as outgroups, considering that Tatosoma has a close phylogenetic relationship with has character specializations similar to those of Neotropical genera and Sauris is different to Tatosoma and Neotropical genera (Dugdale 1980). The MP estimate was done in the PAUP program* (Swofford 2002), in which all data was treated as no-aditive and with equal weight. To find a MP Phylogenetic tree, we used a Branch-and-bound search in the tree area. Later with the equally parsimonious trees found, the tree was calculated with majority consensus, in which the branch length was calculated using the parsimony model already described in the PAUP* program and the state of appearance classified and mapped (i.e. homoplasy vs. synapomorphy, and autoapomorphy) in the WinClada program (Nixon 2002). 
Additionally, the consistency of the MP tree nodes was estimated by the non-parametric bootstrapping technique (Felsenstein 1985) with 1,000 pseudo replicas, and through the decay index or "Bremer Support" (Bremer 1994) calculated with the program, TreeRot v.3 (Sorenson \& Franzosa 2007).

Markov and Monte Carlo's chains method was used within a Bayesian frame (from now on BMCMC) to estimate the probability a posteriori of phylogenetic trees. The MCMC procedure assures that the trees are sampled in proportion to their probability of occurrence under the morphological evolution model used. The Bayesian phylogenetic analysis was implemented in the Bayes Phylogenies program available on request from Dr. Mark Pagel (m.pagel@rdg.ac.uk) on the website, http://www. evolution.rd.ac.uk/BayesPhy.html (Pagel \& Meade 2004). For the a posteriori of the trees' parameters through the chains in this analysis, the Markov process was started with a random tree and a priori uniform probability.

Approximately 50,072,000 phylogenetic trees were generated utilizing the BMCMC procedure, subsampling each 1,000 trees to assure that the successive samples were independent. To assure that the Markov process reached a stable equilibrium (i.e. Markov series convergence zone), the authenticity values of the sample points were graphed in function of the adjacent generations in the series. All the trees before the point in which the authenticity values reached the stationary distribution, were ruled out (i.e. burned $=30$ trees); later only the leftover sample was used to estimate the a posteriori probability distribution of phylogenetic trees. To assure that the analysis would not end up in a local optimum, five independent processes were done. It was considered that the independent analyses converged if the authenticity values by means of the convergence zone were similar (Huelsenbeck \& Bollback 2001).

The morphological evolution model that was used in the BMCMC estimate was the morphological model of irreversible time (from now on, M2P) that uses encoded characters like 0 or 1 , this model allows the rate of evolutionary change from 0 to 1 to differ from the rate of change of 1 to 0 . Finally, to obtain the phylogenetic hypothesis based on probabilities the tree samples from the convergence zone of our BMCMC analysis were imported to the PAUP program (Swofford 2002), and a consensus was estimated from the majority principle of the 50,043 trees constructed with the M2P model, in this tree the node frequency is equivalent to the probability that the node is the true node.

The list of characters and codes used is shown is tables I, II, and III for 16 taxa and 33 characters. The taxa that have been chosen are the 16 genera from the Trichopterygini tribe that live in the studied region and are endemic to this area. The objective of this analysis is to establish the phylogenetic relationship between them and if their endemism also responds to a monophyly.

\section{RESULTS}

South American Austral Trichopterygini

\section{Differential Diagnosis}

The Trichopterygini are easily distinguished from other Larentiinae because the males have a lobe, lapel, flap or vesicle at the base of the hindwings; and a sternal pouch is present at the base of the abdomen.

\section{MorPHOLOGY}

The appearance of moths is shown in figures 4 to 7 . Head, front swollen, light or dark brown or mottled spots; vertex concolorous with the front; ocellus absent; chaetosemata present. Antenna simple in females, ciliated or rhopaliform in males (Fig. 1a). Labial palps similar in color to the head; middle segment usually 4 times longer than the distal segment. Maxillary palps very short. Thorax similar in color to the wings, generally light or dark brown, sometimes mottled, without tufts. Metaepimeron swollen. Legs concolorous with thorax and wings, usually darker on the outside and lighter region on the inner; epiphysis present (Fig. 1b); tibial formula 0-2-4 (Fig. 1c); male metathoracic tibia with hair pencil (Fig. 1d). Forewings normal, subtriangular, never reduced; female hindwings normal, male hind wing with a lobe, lapel, vesicle or flap and sometimes with a tail. Female forewings and hindwings large, smaller in male. Forewings of most species have a brown (light, dark or reddish), other green, yellow and pink; discal spot when present always dark brown; basal, antemedial, postmedial and adterminal bands always present (Figs 4 and 7); some genera with a small set of dark scales on the anal margin of the wing (v. gr. Triptila). Hindwings white, ashy, light brown or reddish brown (Figs. 4 and 7). Forewing venation with two accessory cells, $\mathrm{R}_{2-5}$ arising from apex of the second accessory cell, $\mathrm{R}_{2-4}$ stalked; $\mathrm{M}_{2}$ arising from the middle between $\mathrm{M}_{1}$ and $\mathrm{M}_{3}$; with anal vein. Hindwing venation with Sc and Rs joined through a transverse or parallel vein in the male, anastomosing in female; Rs and $\mathrm{M}_{1}$ arise from the same point, stalked or separate in the male, in the female always stalked; $M_{2}$ closer to $M_{3}$ than $M_{1} ; \mathrm{Cu}_{1}$ closer to $\mathrm{M}_{3}$ than $\mathrm{Cu}_{2}$ or at an equal distance; sometimes only a vein $\mathrm{Cu}$ (Llampidken). In other genera (Rhopalodes and Sauris) $\mathrm{Cu}_{1}$ anastomose with $\mathrm{M}_{3}$ in the male. Females with one or two anal veins, $\mathrm{A}_{2}$ and $\mathrm{A}_{3}$ (Arrayanaria and Rindgenaria); males without, with one, two and three anal veins, these associated lobe; in Triptila and Triptiloides $\mathrm{A}_{1}$ and $\mathrm{A}_{2}$ are stalked. In Lagynopteryx with a structure, apparently to produce sound (Figs. 1e and 1f). Dorsal surface of abdomen simple, without tufts, concolorous with wings; ventral surface always clearer. Pregenital abdominal segments of male with modifications, with a sternal pouch (hypertrophy of the second abdominal sternite) that does not occlude the tympanic opening and bears two digitiform glands inside 
(Figs. 2a and 2b). Intersegmental pleura of abdominal segments 7 and 8 in Lagynopteryx with coremata on each side (Fig. 2c). Posterior edge of sternite 8 of Triptila with a row of setae (Fig. 2d). Pregenital segments of the female without modifications.

Male Genitalia. Uncus simple acute or with rounded apex; socii absent or present, when present it is reduced to a cushion-like, digitiform structure (like in Llampidken); gnathos present (Llampidken) or absent, when present digitiform; anellus of different forms, such as plates or subtubular, with lateral or mid-projections in their hind region; valves simple, with a fissure in the cucullus area or without one (Pachrophylla); sacculus, absent or present (Fueguina and Danielaparra); simple or armed costa (Llampidken and Lagynopteryx); saccus-vinculum modified into different shapes. Aedeagus straight or ventrally curved; vesica unarmed or armed by a cornutus or group of spines.
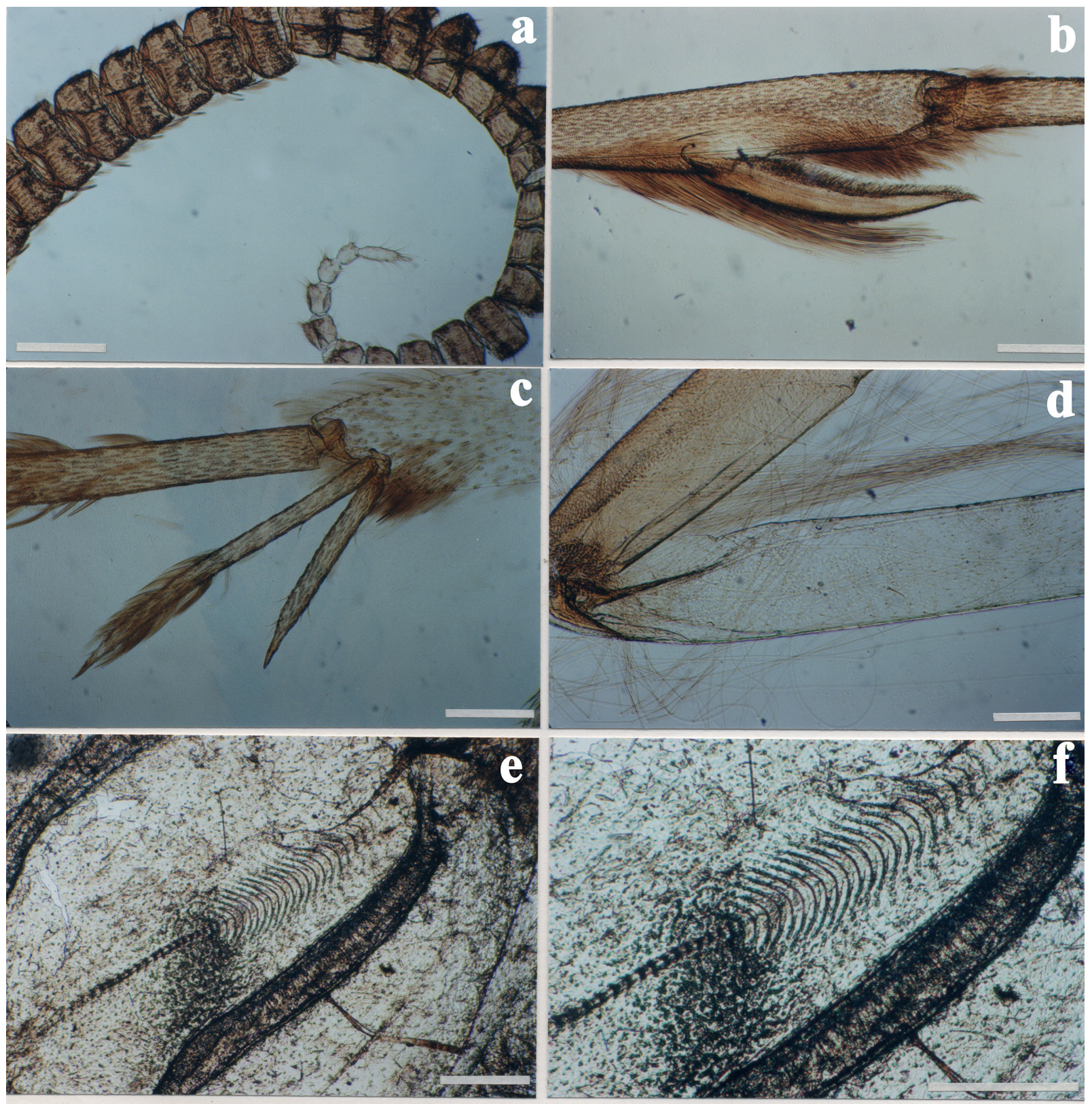

FigURE 1. a) Antenna "rhopaliform", b) epiphysis in lateral view, c) apical spurs of the metathoracic tibia and d) hair pincel of the metathoracic tibia of Triptila virescens (Philippi). e) and f) the hindwing of the male with stridulator organ of Lagynopteryx botulata (Felder \& Rogenhofer). Scale $200 \mu \mathrm{m}$. / a) Antena "ropaliforme", b) epífisis en vista lateral, c) espolones apicales de la tibia metatorácica y d) pincel de pelos de la tibia metatorácica de Triptila virescens (Philippi). e) y f) ala posterior del macho en donde se muestra un órgano estridulador de Lagynopteryx botulata (Felder \& Rogenhofer). Escala $200 \mu \mathrm{m}$. 
Female genitalia. Anterior part of the corpus bursae well developed or reduced (Triptila), membranous, with a belt or an area of microspines (signum) in some cases, posterior portion is tubular, membranous, or sclerotized; ductus bursae, sub-rectangular, quadrangular or tubular, sclerotized or membranous; in the ductus bursae sclerotized areas called colliculum and cestum, the former is the sclerotized area attached to the sterigma and the latter an area that appears in the ductus bursae, but closer to the corpus than to the sterigma (terminology following Dugdale 1980); posterior apophyses generally two times longer than the anterior. With a small ventral sclerite and posterior to the sterigma (corresponds to the ninth sternite).

TRICHOPTERYGINI PHYLOGENY

Preliminary Considerations

No phylogenetic analysis exists in this group for southern South America; on a loosely related note, the only ones are given by Dugdale (1980). This work indicates that the
Neotropical species are more closely related to the New Zealand genera Tatosoma than to the Australian genera. The apomorphic characters of the male that indicate this relationship are: metaepimeron swollen, hypertrophy of the second abdominal segment and the sternal pouch or sac not occluding the tympanic opening. Hypertrophy of the second abdominal segment is also present in Episteira (Oriental and Australian region), Protosteira (Ethiopia and Madagascar) and in Hypocometa (Oriental Region, Borneo). The absence of the sternal pouch is associated with the lack of hair pencil on the male's metathoracic tibia, as in Aposteira (Ethiopic Region, South Africa).

As an external group for comparison the genus Tatosoma has been used, given the affinities already cited that are present with the Neotropical fauna, and the Australian genus Sauris (Dugdale's data 1980). For the analysis, various species from the New Zealand genus were used, whose appearances were compared with the genera of the study region.
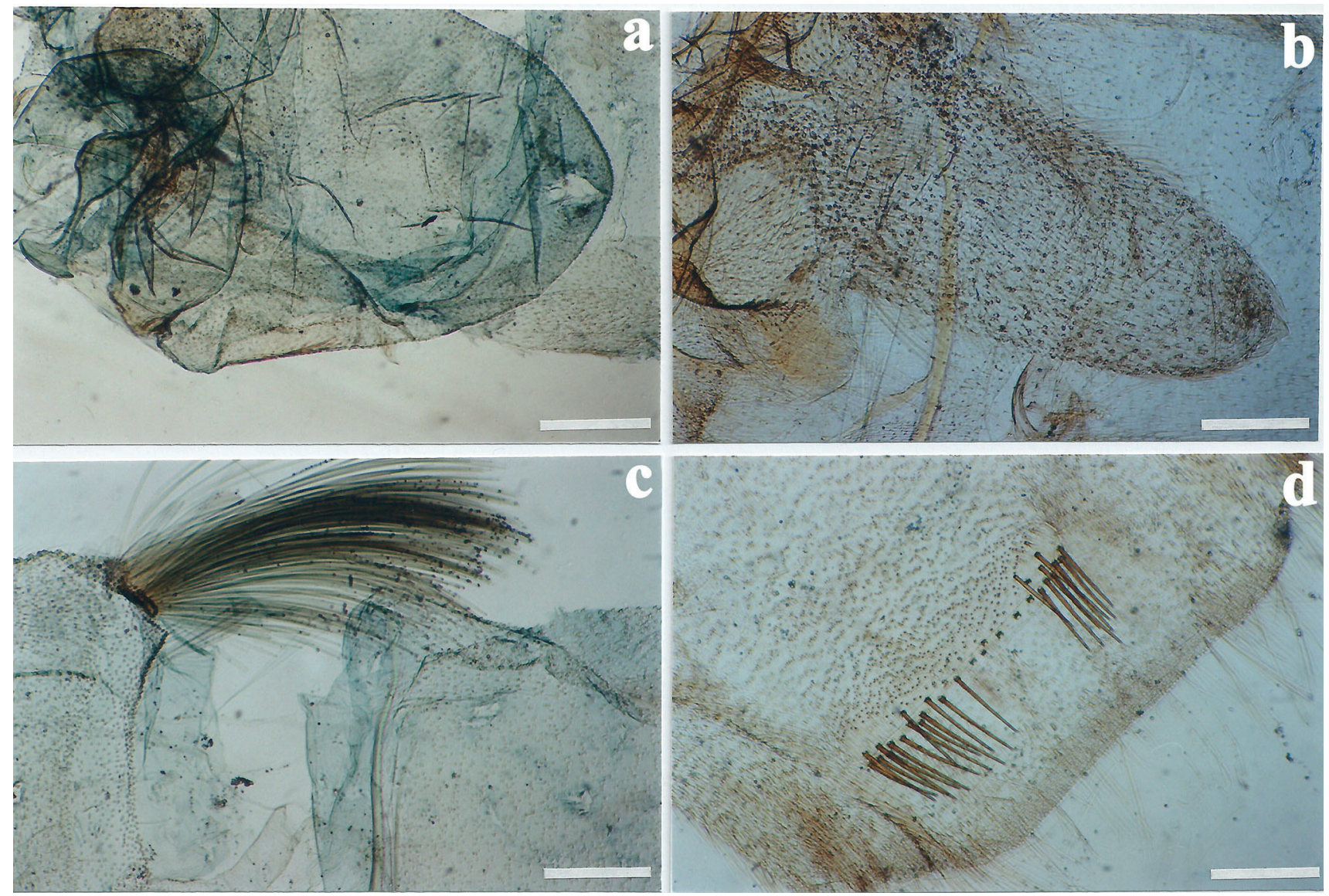

Figure 2. Males sternal pouch of a) Triptila virescens (Philippi) and b) Lagynopteryx botulata (Felder \& Rogenhofer). c) Intersegmental coremata in the abdomen of a male of L. botulata. d) setae in the eighth abdominal sternite male of T. virescens. Scale $200 \mathrm{~m}$. / Bolsa esternal de machos de a) Triptila virescens (Philippi) y b) Lagynopteryx botulata (Felder \& Rogenhofer). c) Coremata intersegmental en el abdomen de un macho de L. botulata. d) cerdas en el octavo esternito abdominal en macho de T. virescens. Escala $200 \mu \mathrm{m}$. 
Phylogenetic AnAlysis

The phylogenetic pattern for the Trichopterygini of the region under study (see figure 3, the majority consensus tree of the 191 trees equally parsimonious obtained from the Branchand-bound research length of the tree $=85$, consistency index $=0.81$, retention index $=0.73$ ) was reached comparing the characters with Tatosoma and Sauris (external groups). Tatosoma shares many characters with the neotropical genera and the monophyly of them is based on (Tables 1 and 2): 1(1) metathoracic tibia with a pair of spurs; 3(1) hair pencil on the male's metathoracic tibia; 5(1) swollen metaepimeron; 6(1) sternal pouch does not occlude the tympanic opening; and 7 (1) two areoles on the anterior wings. The monophyly of Trichopterygini from the area under study is based on: 15(1) absence of spatulate uncus; 20(1) very developed saccusvinculums; 21(1) anellus extends into a few processes; and 33(1) absence of cervix bursae.

According to the MP analysis the tribe is divisible in Llampidken and a branch that includes all the other genera; this is established based on an apomorphy: 18(1) absence of a costal arm (Tables 1, 2, and 3). The Bayesian inference analysis shows Pachrophylla as the sister group of the genera in the South of South America, even though the $a$ posteriori probability values are very low. Within this last branch, the cladistics structure is not well resolved even though certain branches are evident and have relatively high Bootstrap and Bremer support values in the MP analysis, and high a posteriori probability values in the Bayesian inference analysis. In these last ones, there is the Arrayanaria + Butleriana + Rindgenaria + Triptiloides + Tomopteryx + Triptila, with a high a posteriori probability value (0.90), however this is not reflected in the MP analysis given that there are no synapomorphies that sustain it. The branch Triptoloides + Tomopteryx + Triptila, sustained by synapomorphy 11(1): presence of vein $\mathrm{A}_{1}$ pedunculated with $\mathrm{A}_{2}$ in the male's hindwing, a high support of the Bootstrap analysis appears (81\%), a decay index of 1 , and an a posteriori probability value of 0.78 . The other branch with a high a posteriori probability (0.89) and Bootstrap support measurement of $85 \%$ is Triptila + Tomopteryx, sustained by apomorphy 12(1) with an indention between veins, $\mathrm{Cu}_{1}$ and $\mathrm{Cu}_{2}$.

TABLE 1. Polarized characters for the phylogenetic analysis of the genera of the Trichopterygini in the present study / Caracteres polarizados para el análisis filogenético de los géneros de Trichopterygini del presente estudio.

1. Metathoracic tibia with a few spurs (1); without spurs $(0)$

2. Male metathoracic tibia with reduced spurs (1); normal (0)

3. Male metathoracic tibia with hair pencil (1); without hair pencil (0)

4. Line of bristles on the posterior margin of the male's eighth sternite (1); no bristles (0)

5. Metaepimeron swollen (1); normal (0)

6. Sternal pouch does not occlude the tympanic opening (1); occludes $(0)$

7. Forewings with two areoles (1); with one (0)

8. Male's hindwings with a vesicle or flap (1); lobe (0)

9. Male's hindwings with Sc and Rs veins anastomosed (1); united by a transversal vein (0)

10. Male's hindwings with three anal veins (3); one (2); zero (1); two (0)

11. Male's hindwings $A_{1}$ and $A_{2}$ veins pedunculated (1); free (0)

12. Male's hindwings with an indention between $\mathrm{Cu}_{1}$ and $\mathrm{Cu}_{2}$ veins (1); without indention (0)

13. Male's hindwings with an indention between $\mathrm{Cu}_{2}$ and $\mathrm{A}_{1}$ veins (1); absent (0)

14. Male's hindwings with a tail (1); absent (0)

15. Uncus does not have the form of a spatula (1); has a spatula form (0)

16. Sacculus arm present (1); absent (0)

17. Sacculus arm's form: boot (2); bifid (1); 1 spiny (0)

18. Costal process absent (1); present (0)

19. Costal process boot shaped (1); fingerlike (0)

20. Developed saccus-vinculum (1); reduced (0)

21. Anellus extends into a few processes (1); quadrangular (0)

22. Valve's apex with an indention (1); without indention (0)

23. Valve's apex with a deep indention (1); shallow (0)

24. Valve's apex with ventral indention (1); mid-region indention (0)

25. Costal margin with a palpebral form appendix (1); without this appendix (0)

26. Cucullus rotated $90^{\circ}$ towards the ventral region (1); posterior $(0)$

27. Coremata of the valve absent (1); present (0)

28. Gnathos present (1); absent (0)

29. Uncus with an apex (1); simple (0)

30. Aedeagus with ventral curve (1); normal, straight (0)

31 . Spiny anellus process $(1)$; bare $(0)$

32. Corpus bursae reduced (1); developed (0)

33. Cervix bursae (1); present (0)

(1), (2), (3) derived states or apomorphic; (0) plesiomorphy. 
TABLE 2. Polarized character matrix for the genera from Trichopterygini, based on Table 1, to construct a phylogenetic cladogram / Matriz de caracteres polarizados de los géneros de Trichopterygini, basada en la Tabla 1 para la construcción del cladograma.

\begin{tabular}{l|ccccccc}
\hline Taxa & CHARACTERS & \multicolumn{7}{l}{} & & & & \\
\hline Sauris & 00000 & 00000 & 00000 & 00000 & 00000 & 00000 & 000 \\
Tatosoma & 10101 & 11000 & $? 0000$ & 01000 & $00 ? 00$ & 00000 & 000 \\
Arrayanaria & 10101 & 11010 & $? 0001$ & $1 ? 1 ? 1$ & 11000 & 01000 & 101 \\
Butleriana & 10101 & 11012 & $? 0001$ & $1 ? 1 ? 1$ & 11000 & 01000 & 001 \\
Danielaparra & 10101 & 11000 & $? 0001$ & $021 ? 1$ & 11000 & 01000 & 101 \\
Fueguina & 10101 & 11000 & $? 0001$ & $001 ? 1$ & 11100 & 01000 & 001 \\
Hoplosauris & 10101 & 11202 & $? 0001$ & $1 ? 1 ? 1$ & $10 ? 00$ & 00000 & 001 \\
Lagynopteryx & 10101 & 11111 & $? 0011$ & $1 ? 1 ? 1$ & $10 ? 00$ & 01000 & 001 \\
Llampidken & 10101 & 11001 & $? 0001$ & $1 ? 011$ & $10 ? 00$ & 01100 & 001 \\
Pachrophylla & 11101 & 11000 & $? 0001$ & $1 ? 1 ? 1$ & $10 ? 00$ & 01000 & 001 \\
Parapachrophylla & 10101 & 11000 & $? 0001$ & $1 ? 1 ? 1$ & 11001 & 01000 & 001 \\
Rindgenaria & 10101 & 11013 & 00001 & $1 ? 1 ? 1$ & 11000 & 11000 & 001 \\
Tomopteryx & 10101 & 11003 & 11001 & $1 ? 1 ? 1$ & 11010 & 01000 & 001 \\
Triptila & 10111 & 11003 & 11001 & $1 ? 1 ? 1$ & 11000 & 01001 & 011 \\
Triptiloides & 10101 & 11003 & 10101 & $1 ? 1 ? 1$ & 11000 & 01000 & 001 \\
Warrenaria & 10101 & 11000 & $? 0001$ & $1 ? 1 ? 1$ & 11000 & 01010 & 001 \\
\hline
\end{tabular}

Plesiomorphic character; (1), (2) y (3) apomorphic states and derived states; (?) lost character or not applicable.

TABLE 3. Matrix of the polarized character states for the Trichopterygini genera, based on Tables 1 and 2, for the Bayesian Inference analysis / Matriz de caracteres polarizados de los géneros de Trichopterygini, basados en las Tablas 1 y 2, para el análisis de Inferencia Bayesiana.

\begin{tabular}{|c|c|c|c|c|c|c|c|c|c|c|c|c|c|c|}
\hline TAXA & Chara & TERS & & & & & & & & & & & & \\
\hline Sauris & 10101 & 01010 & 10101 & 00101 & 00010 & 10101 & 01010 & 10101 & 01010 & 10101 & 01010 & 10101 & 01010 & 1010 \\
\hline Tatosoma & 01100 & 11001 & 01011 & 00101 & $000 ? ?$ & 10101 & 01010 & 01101 & 01010 & $10 ? ? 1$ & 01010 & 10101 & 01010 & 1010 \\
\hline Arrayanaria & 01100 & 11001 & 01011 & 00011 & $000 ? ?$ & 10101 & 00101 & $? ? 01 ?$ & $? 0101$ & 01101 & 01010 & 01101 & 01001 & 1001 \\
\hline Butleriana & 01100 & 11001 & 01011 & 00010 & $100 ? ?$ & 10101 & 00101 & $? ? 01 ?$ & $? 0101$ & 01101 & 01010 & 01101 & 01010 & 1001 \\
\hline Danielaparra & 01100 & 11001 & 01011 & 00101 & $000 ? ?$ & 10101 & 00110 & $0101 ?$ & $? 0101$ & 01101 & 01010 & 01101 & 01001 & 1001 \\
\hline Fueguina & 01100 & 11001 & 01011 & 00101 & $000 ? ?$ & 10101 & 00110 & $1001 ?$ & $? 0101$ & 01011 & 01010 & 01101 & 01010 & 1001 \\
\hline Hoplosauris & 01100 & 11001 & 01010 & 01100 & $100 ? ?$ & 10101 & 00101 & $? ? 01 ?$ & $? 0101$ & $100 ? ? 1$ & 01010 & 10101 & 01010 & 1001 \\
\hline Lagynopteryx & 01100 & 11001 & 01010 & 10010 & $010 ? ?$ & 10100 & 10101 & $? ? 01 ?$ & $? 0101$ & $10 ? ? 1$ & 01010 & 01101 & 01010 & 1001 \\
\hline Llampidken & 01100 & 11001 & 01011 & 00100 & $010 ? ?$ & 10101 & 00101 & $? ? 100$ & 10101 & $10 ? ? 1$ & 01010 & 01011 & 01010 & 1001 \\
\hline Pachrophylla & 01010 & 11001 & 01011 & 00101 & $000 ? ?$ & 10101 & 00101 & $? ? 01 ?$ & $? 0101$ & $10 ? ? 1$ & 01010 & 01101 & 01010 & 1001 \\
\hline Parapachrophylla & 01100 & 11001 & 01011 & 00101 & $000 ? ?$ & 10101 & 00101 & $? ? 01 ?$ & $? 0101$ & 01101 & 00110 & 01101 & 01010 & 1001 \\
\hline Rindgenaria & 01100 & 11001 & 01011 & 00010 & 00110 & 10101 & 00101 & $? ? 01 ?$ & $? 0101$ & 01101 & 01001 & 01101 & 01010 & 1001 \\
\hline Tomopteryx & 01100 & 11001 & 01011 & 00100 & 00101 & 01101 & 00101 & $? ? 01 ?$ & $? 0101$ & 01100 & 11010 & 01101 & 01010 & 1001 \\
\hline Triptila & 01100 & 10101 & 01011 & 00100 & 00101 & 01101 & 00101 & $? ? 01 ?$ & $? 0101$ & 01101 & 01010 & 01101 & 00110 & 0101 \\
\hline Triptiloides & 01100 & 11001 & 01011 & 00100 & 00101 & 10011 & 00101 & $? ? 01 ?$ & $? 0101$ & 01101 & 01010 & 01101 & 01010 & 1001 \\
\hline Warrenaria & 01100 & 11001 & 01011 & 00101 & $000 ? ?$ & 10101 & 00101 & $? ? 01 ?$ & $? 0101$ & 01101 & 01010 & 01100 & 11010 & 1001 \\
\hline
\end{tabular}


Fueguina and Danielaparra are sustained by the presence of a sacculus arm; however, there is not enough statistic evidence given that the character studied is also present in Tatosoma. The automorphies for each genus are indicated in Table 1 and Figure 3. The phylogenetic pattern presented here only represents a first attempt to establish the relationship between the taxa of the tribe. The various genus-level branches will be much better when the immature stages and biological data can be included (morphological aspects and behavioral patterns of the eggs, larvae, and pupae).

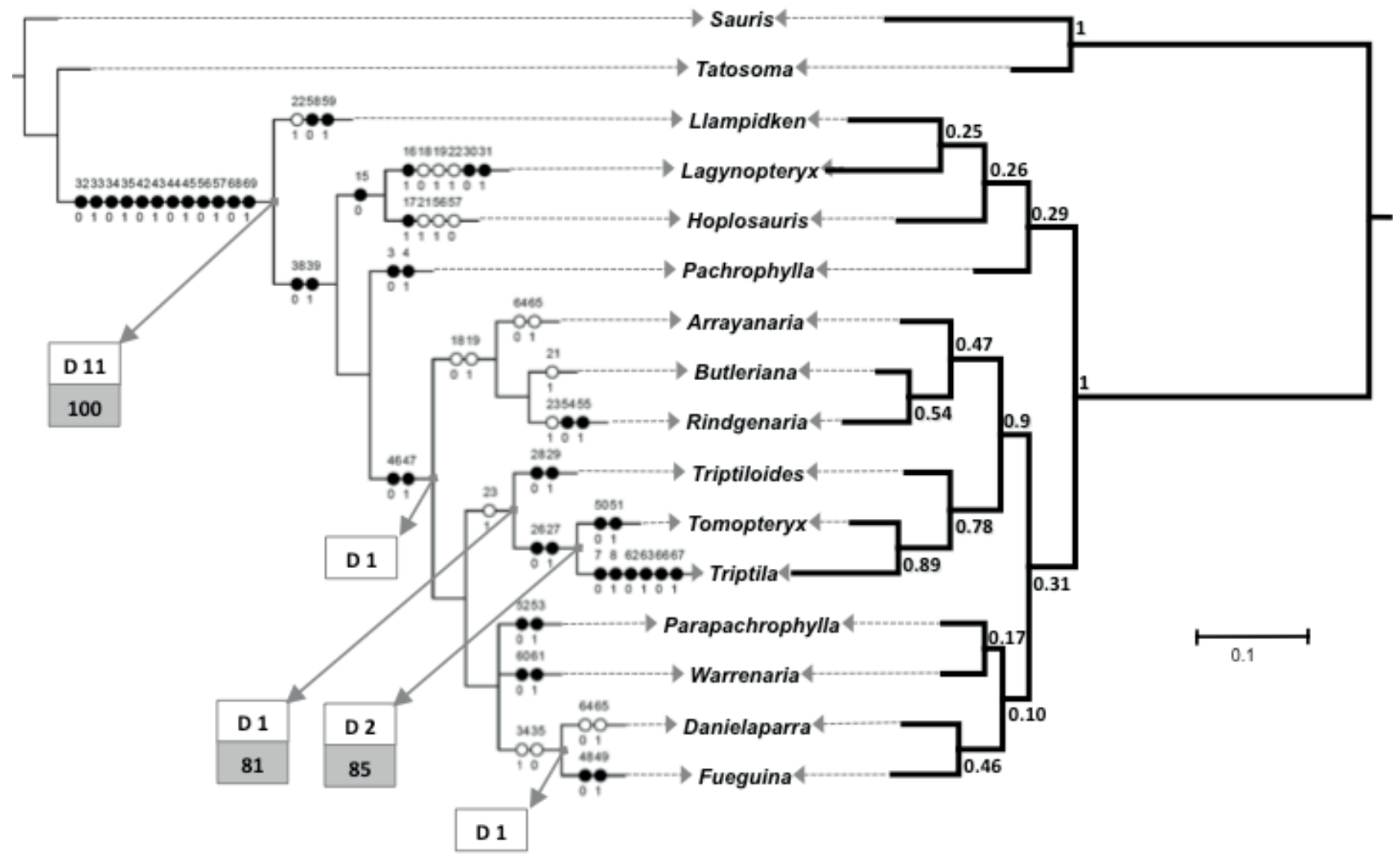

FiguRE 3. (A) Maximum parsimony optimality criterium: majority rule consensus tree based on 191 equally most-parsimonious trees obtained using an exhaustive search (Tree length $=85$, Consistency index $=0.81$, Retention index $=0.73$ ). The character states were mapped using WinClada Software (Nixon 2002) over the tree branches, with the characters coded in 0 and 1. Black circles indicate nonhomplasious changes (synapomorphies or autapomorphies), and white circles show homoplasies. The gray node label shows the percentage of bootstrap replicates greater than $50 \%$, and the white node labels shows the Decay values or "Bremer support". (B) Bayesian inference: majority-rule consensus of 50.043 trees constructed from the M2P model. The branch length corresponds to the average branch length of the sample of trees. The numbers at the nodes are posterior probabilities. This is the number of times that a particular node appeared in the MCMC sample and is interpreted as the posterior belief that the node is true. / (A) Criterio de optimización de Máxima Parsimonia: árbol de consenso de la regla de la mayoría basado en 191 árboles parsimoniosos de igual longitud bajo una búsqueda exhaustive (longitud del árbol = 85, índice de consistencia $=0,81$, índice de retención $=0,73$ ). Los números de los caracteres en las ramas del árbol se estableció utilizando WinClada (Nixon 2002). Los círculos negros indican apomorfías (sinapomorfías o autapomorfías), los círculos blancos muestran homoplasias. La etiqueta gris muestra el porcentaje de apoyo superior a 50\% en Bootstrapping y las etiquetas blancas los valores del índice de decaimiento o "Bremer support". (B) Inferencia bayesiana: árbol de consenso de la regla de mayoría de 50.043 árboles construidos a partir del modelo M2P. La longitud de la rama corresponde a la longitud media de la rama de la muestra de árboles. Los números en los nodos son las probabilidades posteriores. Este es el número de veces que un determinado nodo apareció en la muestra MCMC y que es interpretado como la probabilidad posterior de que el nodo es verdadero. 


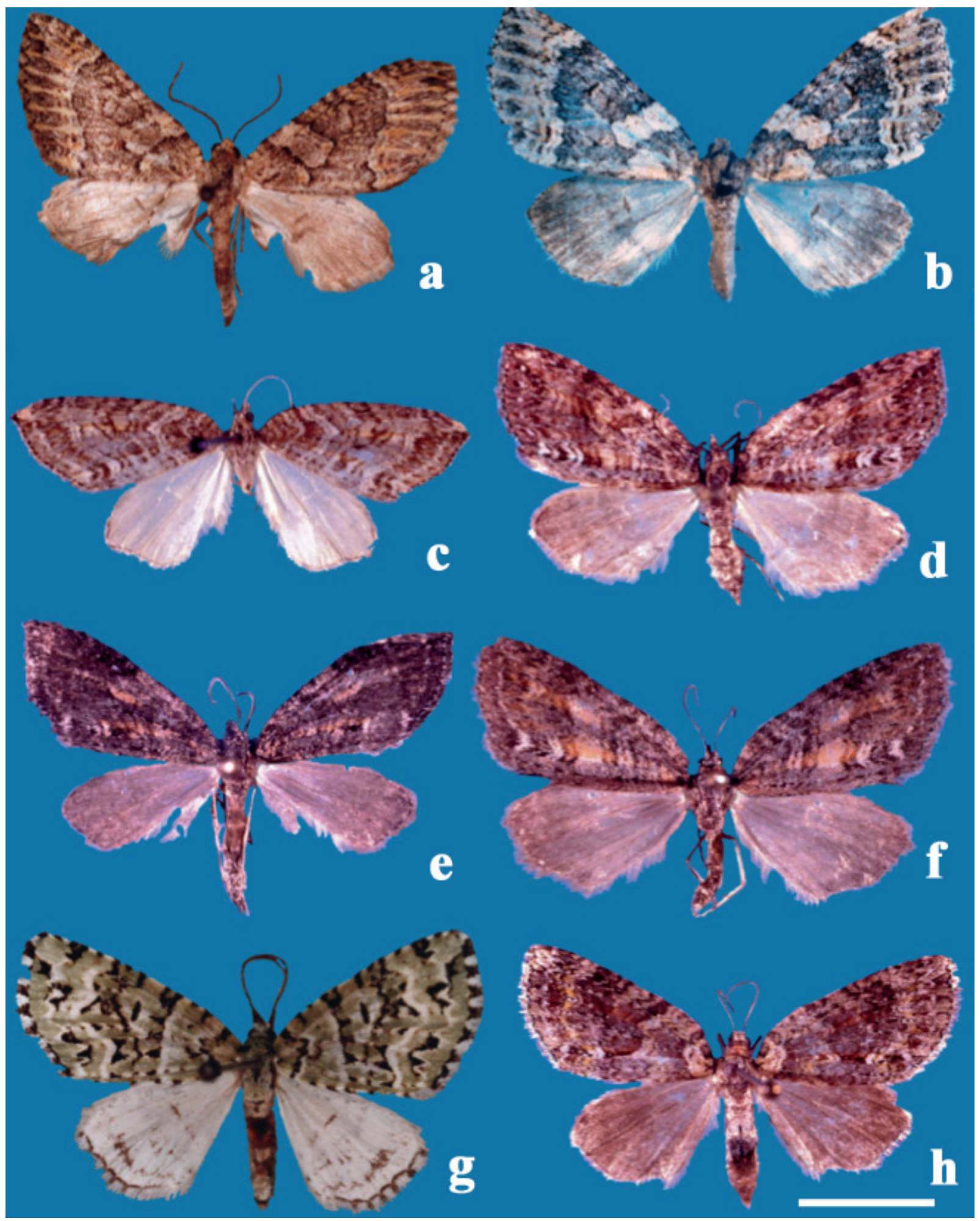

Figure 4. Imago in dorsal view of: a) male and female Arrayanaria santiaguensis Parra, c and d) male of Butleriana fasciata (Butler) and female B. minor (Butler), e and f) male and female B. fumosa (Butler), g) female of Danielaparra fragmentata (Dognin), and h) male of Fueguina varians (Butler). Scale $1 \mathrm{~cm}$. / Imagos en vista dorsal de: a y b) macho y hembra de Arrayanaria santiaguensis Parra, c y d) macho de Butleriana fasciata (Butler) y hembra de B. minor (Butler), e y f) macho y hembra de B. fumosa (Butler), g) hembra de Danielaparra fragmentata (Dognin), y h) macho de Fueguina varians (Butler). Escala $1 \mathrm{~cm}$. 


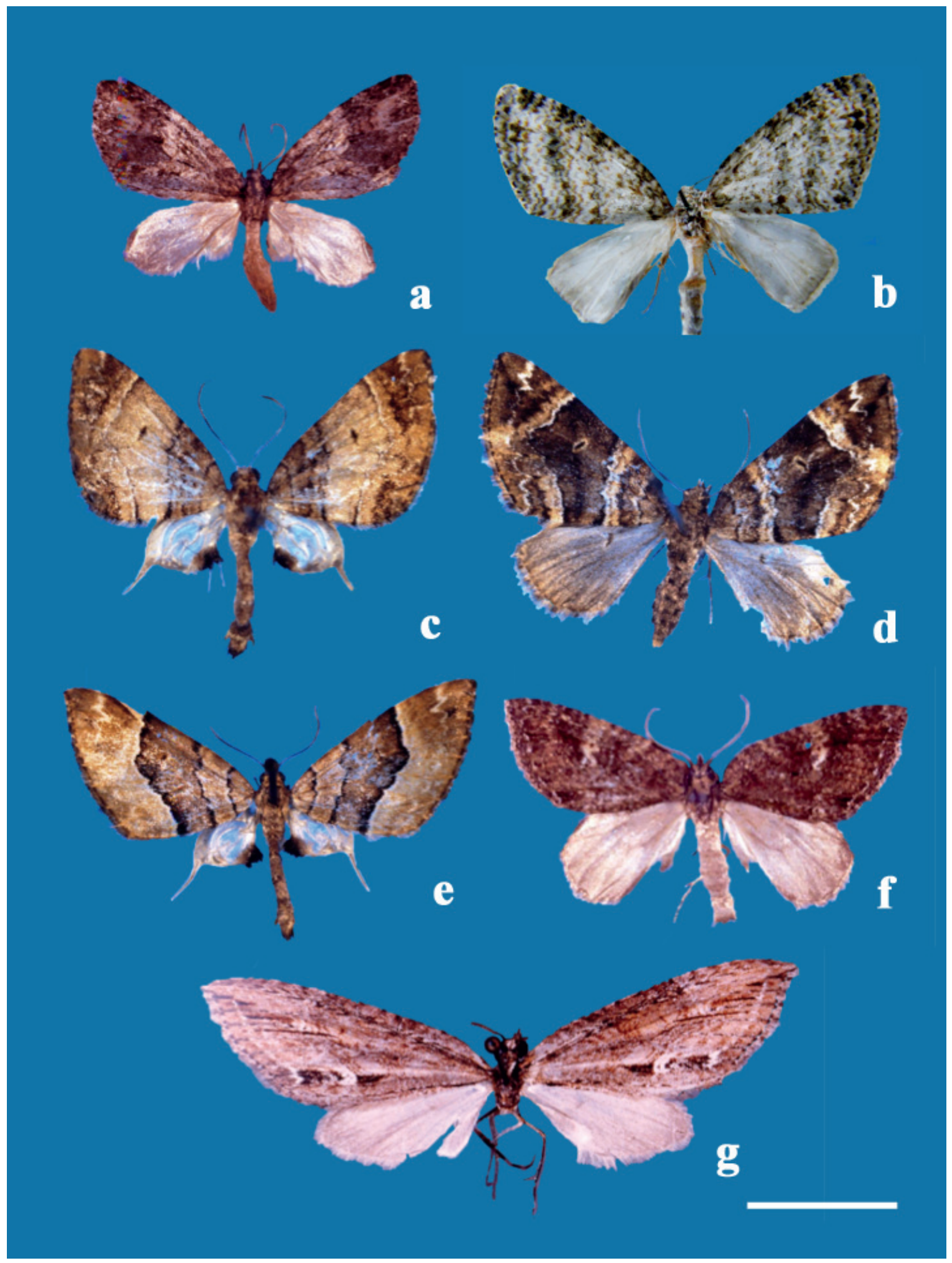

FIgURE 5. Imago in dorsal view of: a) male of Fueguina celovalva Parra, b) male Hoplosauris mabillei Parra, c and e) males of Lagynopteryx botulata (Felder \& Rogenhofer), d) female of L. botulata, f) male of Llampidken moesta (Butler), and g) male of Pachrophylla linearia Blanchard. Scale $1 \mathrm{~cm}$. / Imagos en vista dorsal de: a) macho de Fueguina celovalva Parra, b) macho Hoplosauris mabillei Parra, c y e) machos de Lagynopteryx botulata (Felder \& Rogenhofer), d) hembra de L. botulata, f) macho de Llampidken moesta (Butler), y g) macho de Pachrophylla linearia Blanchard. Escala $1 \mathrm{~cm}$. 


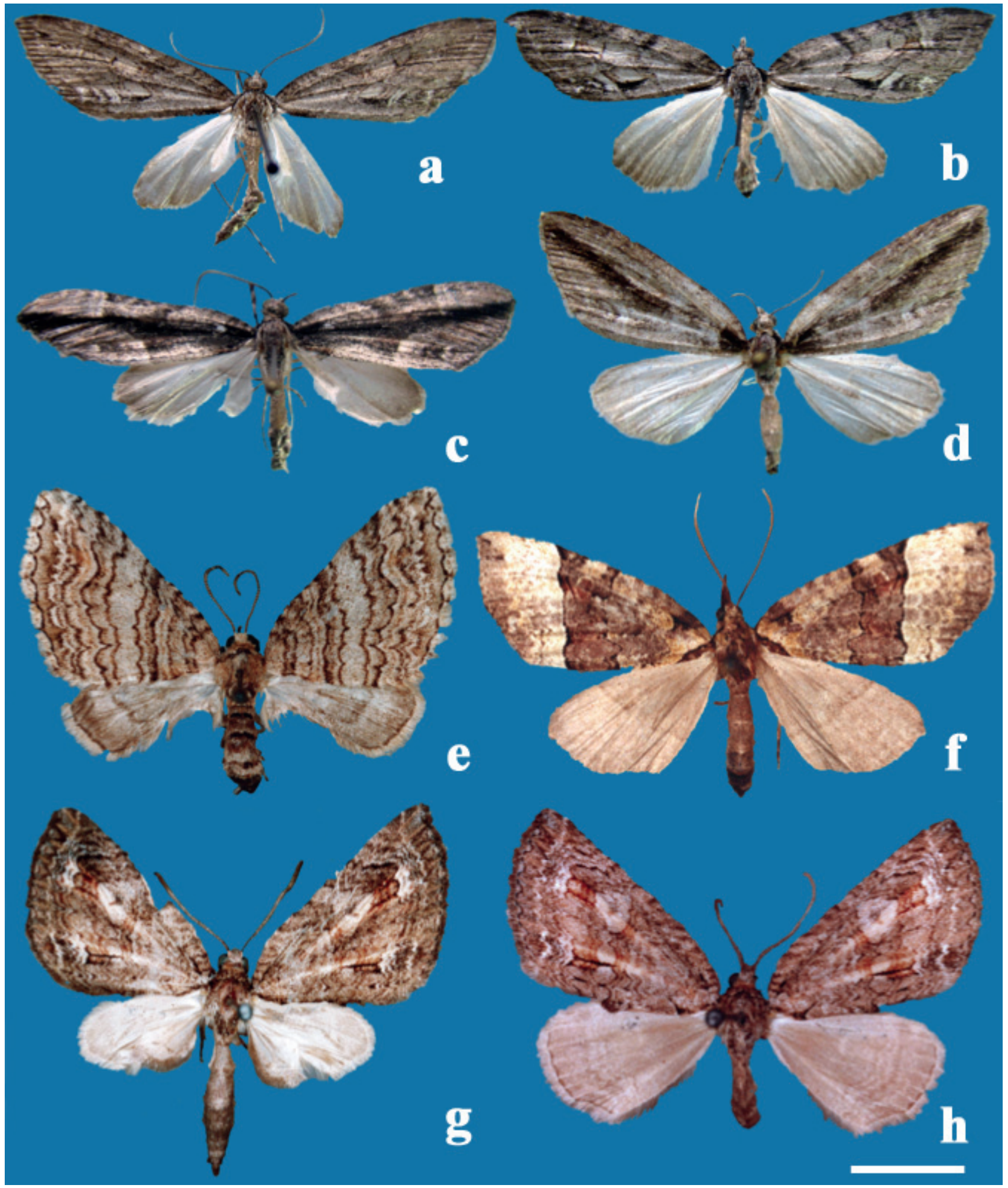

Figure 6. Imago in dorsal view of: a and b) male and female of Parapachrophylla claudiae Parra, $\mathrm{c}$ and d) male and female of $P$. michelleae Parra n. sp., e) male of Rindgenaria multilineata Parra, f) female of Tomopteryx amoena Philippi, and g and h) male and female of Triptila virescens (Philippi). Scale $1 \mathrm{~cm}$. / Imagos en vista dorsal de: a y b) macho y hembra de Parapachrophylla claudiae Parra, c y d) macho y hembra de P. michelleae Parra n. sp., e) macho de Rindgenaria multilineata Parra, f) hembra de Tomopteryx amoena Philippi, y g y h) macho y hembra de Triptila virescens (Philippi). Escala $1 \mathrm{~cm}$. 


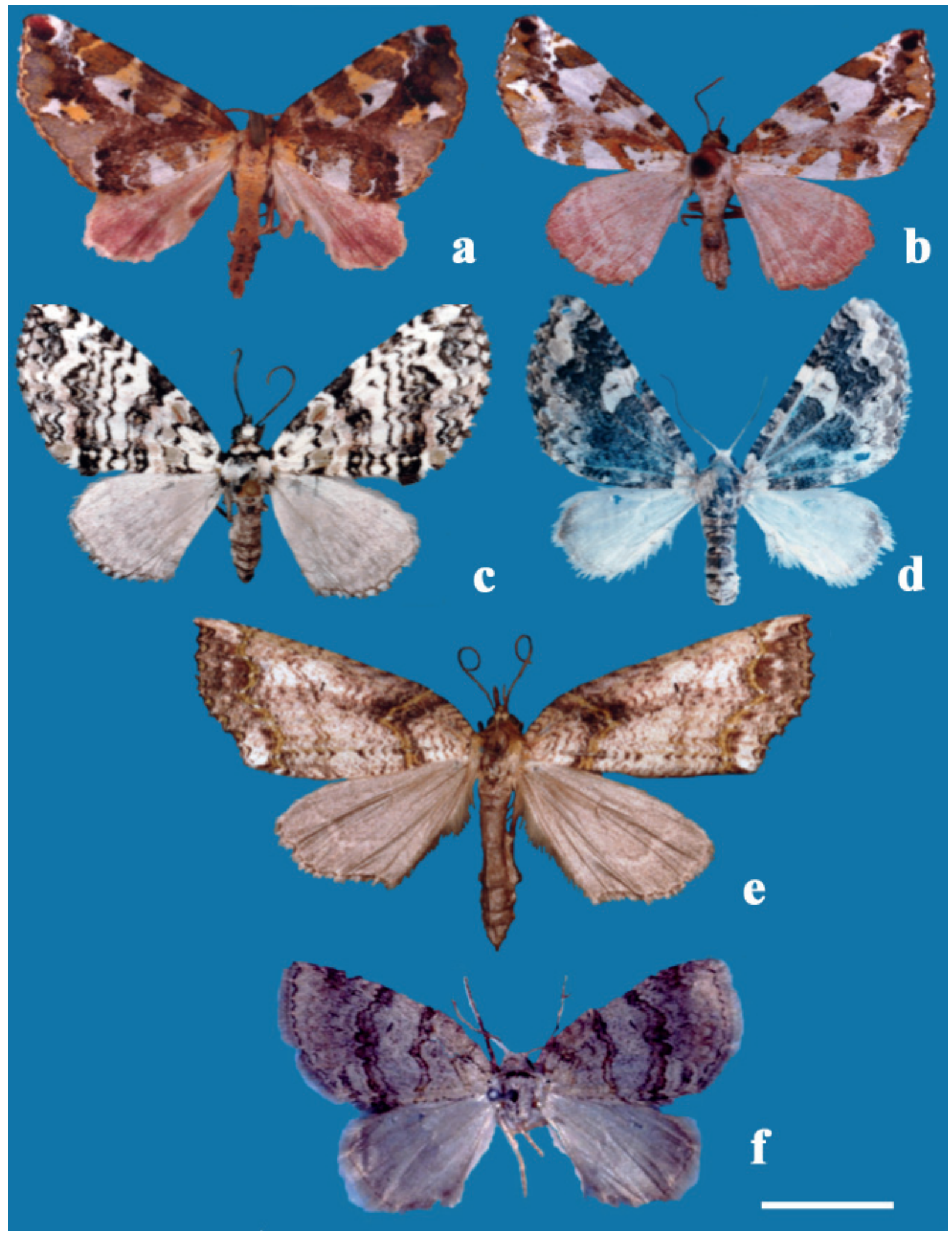

Figure 7. Imago in dorsal view of: a and b) male and female of Triptiloides laeta (Philippi), c) female of T. esmeralda (Bartlett-Calvert), d) male of T. randallae (Sperry, 1951), e) female of T. krahmeri Parra \& Santos-Salas, and f) male of Warrenaria martha (Butler). Scale $1 \mathrm{~cm}$. / Imagos en vista dorsal de: a y b) macho y hembra de Triptiloides laeta (Philippi), c) hembra de T. esmeralda (Bartlett-Calvert), d) macho de T. randallae (Sperry, 1951), e) hembra de T. krahmeri Parra \& Santos-Salas, y f) macho de Warrenaria martha (Butler). Escala $1 \mathrm{~cm}$. 
TAXONOMY. DESCRIPTION OF THE GENERA

\section{Arrayanaria Parra, 1996}

Arrayanaria Parra, 1996:39

Type Species. Arrayanaria santiaguensis Parra, 1996:41. By original designation.

\section{REDESCRIPTION}

The general appearance of the moths is shown in the figures $4 a$ and $b$. Medium sized moths with the length of the forewing varying between 16 and $17 \mathrm{~mm}$.

Ciliate antennae in the male, filifom in the female. Light brown or brownish-gray forewings; all the bands are present, well-marked light brown antemedial and postmedial bands. Ash-gray or light brown hindwings. Forewing venation: with two accessory cells. Hindwing venation: the Sc and Rs veins are united by a transverse vein or anastomosis in the male, regularly anastomosing in the female; Rs and $\mathrm{M}_{1}$ originate from the same point or they are pedunculated in both sexes; in the male with a lobe supplied from two anal veins (Fig. 8d) in the female with two anal veins (Fig. 8e). Legs: tibial formula 0-2-4; male metathoracic tibia with hair pencil. Wings and abdomen are of the same color; sternal pouch is present in the male.

Male genitalia (Figs. 8a-b). Uncus stout, with acute apex: rectangular valvae, swollen, apex with an indention; sacculus absent; anellus sub-rectangular, anellus process armed with microspines, saccus-vinculum sub-triangular, swollen. Aedeagus unarmed or armed.

Female genitalia (Figs. 8c). Corpus bursae membranous and spherical on its anterior half, cylindrical and sclerotized on its posterior half; ductus bursae sclerotized, two times longer than wide; the seminal duct region is membranous; posterior apophyses two times longer than the anterior.

\section{DifFERENTIAL DiAgnosis}

The genus is characterized by the armed anellus. Even though this character is present in Rindgenaria, in the latter it appears associated with other characters that make these genera separate entities. In the female, the ductus bursae are sclerotized and with grooves like on Danielaparra, but weaker. The coloration and pattern of maculation are similar in all the genera of this tribe, therefore, the differentiation between coming genera is difficult. Male genitalia show the most reliable characteristics for the separation of Arrayanaria, in addition to the presence of the two anal veins in the hindwings of the female, provided that this is not repeated in any other genus of the tribe.

\section{DistRIBUTION}

Endemic genus from Chile, distributed in the following biogeographic provinces: Central Valley, Northern Valdivian
Forest, and the Valdivian Forest. A. duofasciata reaches the most southern distribution of the genus (Valdivia).

OBSERVATIONS

In the phylogenetic analysis, an autapomorphy was not found that defines it, the genus is better defined by a combination of characters (see diagnosis).

SPeCies InCluded

arenosa (Bartlett-Calvert, 1890) comb. nov. (Oporabia)

duofasciata Parra, 1996

santiaguensis Parra, 1996

\section{Butleriana Parra, 1991}

Butleriana Parra, 1991:150

Type Species. Pachrophylla minor Butler, 1882:401. By original designation Parra, 1991:151.

\section{REDESCRIPTION}

The general appearance of the moths is shown in the figures $4 \mathrm{c}$-f. Small, medium, or large moths, the length of the forewing varies between 13 and $23 \mathrm{~mm}$.

Head without ocelli; chaetosemata present; simple antennae, as much in the male as in the female. Forewings dark brown or gray, sometimes with cream and pale orange colored spots. Hindwings ashy white, in the males with a very small lobe, thin, completely expanded, narrow and subtriangular, that reaches the middle of the wings' length. Forewing venation: two accessory cells. Hindwing venation: the Sc and Rs veins are anastomosed along the whole length of the cell in both sexes; Rs and $M_{1}$ are pedunculated in both sexes; one anal vein on the lobe, sometimes there is another vein that only is implied on its base (B. fasciata) (Fig. 9d). Legs: Tibial formula 0-2-4; male metathoracic tibia with hair pencil. The male's abdomen has a sternal pouch.

Male genitalia (Figs. 9 a-b). Simple valvae, with a bulbous projection in the central region of the ventral margin, divided apex; uncus variable, aedeagus' vesica armed with spines.

Female genitalia (Fjg. 9c). Ninth sternum absent; corpus bursae spherical, ovoid, or subrectangular; signum present in the form of ring shaped bands or absent: ductus bursae with two sclerotized areas; posterior apophyses two times longer than the anterior.

\section{DifFERENTIAL DIAGNOSIS}

This genus can be recognized because it consists of small species (male's specimens) medium or big (females and some males) (wingspan up to $23 \mathrm{~mm}$ ), of dark brown or gray color, sometimes with cream and light orange colored spots on the forewings. In maculation, the presence of a black stripe close to the anal margin of the hindwings (except 
in $B$. oculata) differentiates this genus from others of the tribe and at the same time moves it closer to Pachrophylla. The diagnostic character of this genera is found on the male hindwings, this is because the lobe is very small, thin, and subtriangular in shape, and has only one anal vein (autoapomorphy of the genus). At the level of the male genitalia make up, this taxon presents an indention on the cucullus region, a trait that is not present in Pachrophylla.

\section{DisTRIBUTION}

Genus endemic to the area under study, it is found distributed in the following biogeographic provinces: Coquimbo Desert, Pehuenar, Valdivian Forest, Valdivian Mountain Range, and the Southern Pacific region. The most widely distributed species within the genus is $B$. minor, and the most Southern B. oculata.

\section{OBSERVATIONS}

The species are those which show the most size diversity within the tribe (wingspan) and their maculation pattern is practically similar in all of them. Given the homogeneity of this maculation, it is necessary to resort to their genital armature to separate the species that form the group. The differences between them reside in the uncus morphology, the vesical (if it is armed or not), the saccus vinculum, the corpus bursae form, and the presence, absence, or reduction of the signum.

Their external appearance is very like the species of Pachrophylla, from there Butler (1882) described them within these genera. This author describes two varieties for the Pachrophylla minor, fundamentally for the slight maculation variation. The analysis of the genital structures made it so that Parra (1991) moved each one of these varieties up to the category of valid species.

Species InCluded fasciata (Butler, 1882) (Pachrophylla) fumosa (Butler, 1882) (Pachrophylla) minor (Butler, 1882) (Pachrophylla) oculata (Mabille, 1885) (Lobophora)
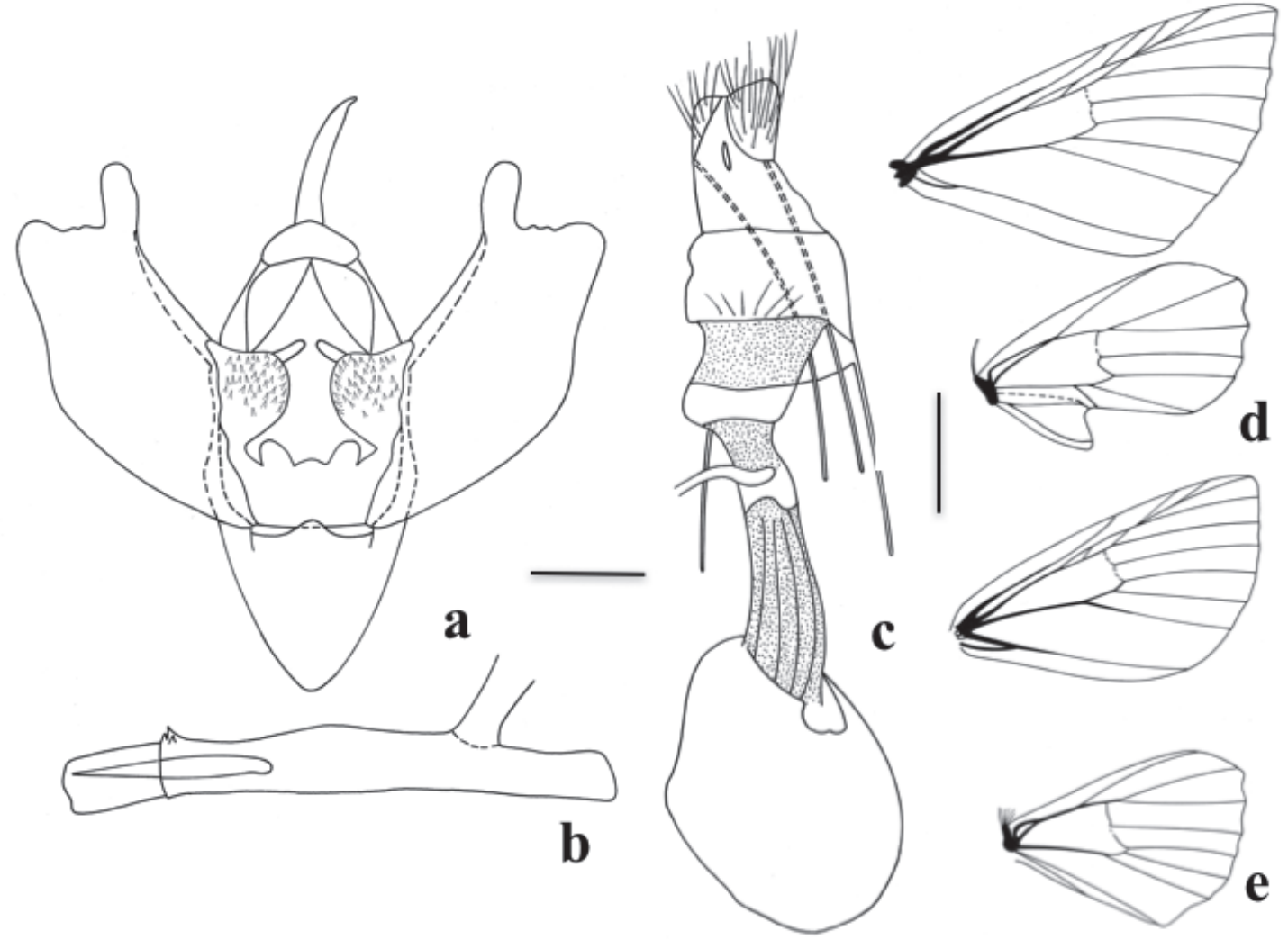

FIGURE 8. Genitalia and wing venation of Arrayanaria santiaguensis Parra. a) male genitalia in ventral view, b) aedeagus in lateral view, c) female genitalia in ventral view, $d$ and e) male and female wings venation. Genitalia scale $0.5 \mathrm{~mm}$, Wing scale $1 \mathrm{~cm}$. / Armaduras genitales y venación alar de Arrayanaria santiaguensis Parra. a) genitalia del macho en vista ventral, b) aedeagus en vista lateral, c) genitalia de la hembra en vista ventral, d y e) venación alas del macho y hembra. Escala genitalia 0,5 mm, Escala alas $1 \mathrm{~cm}$. 


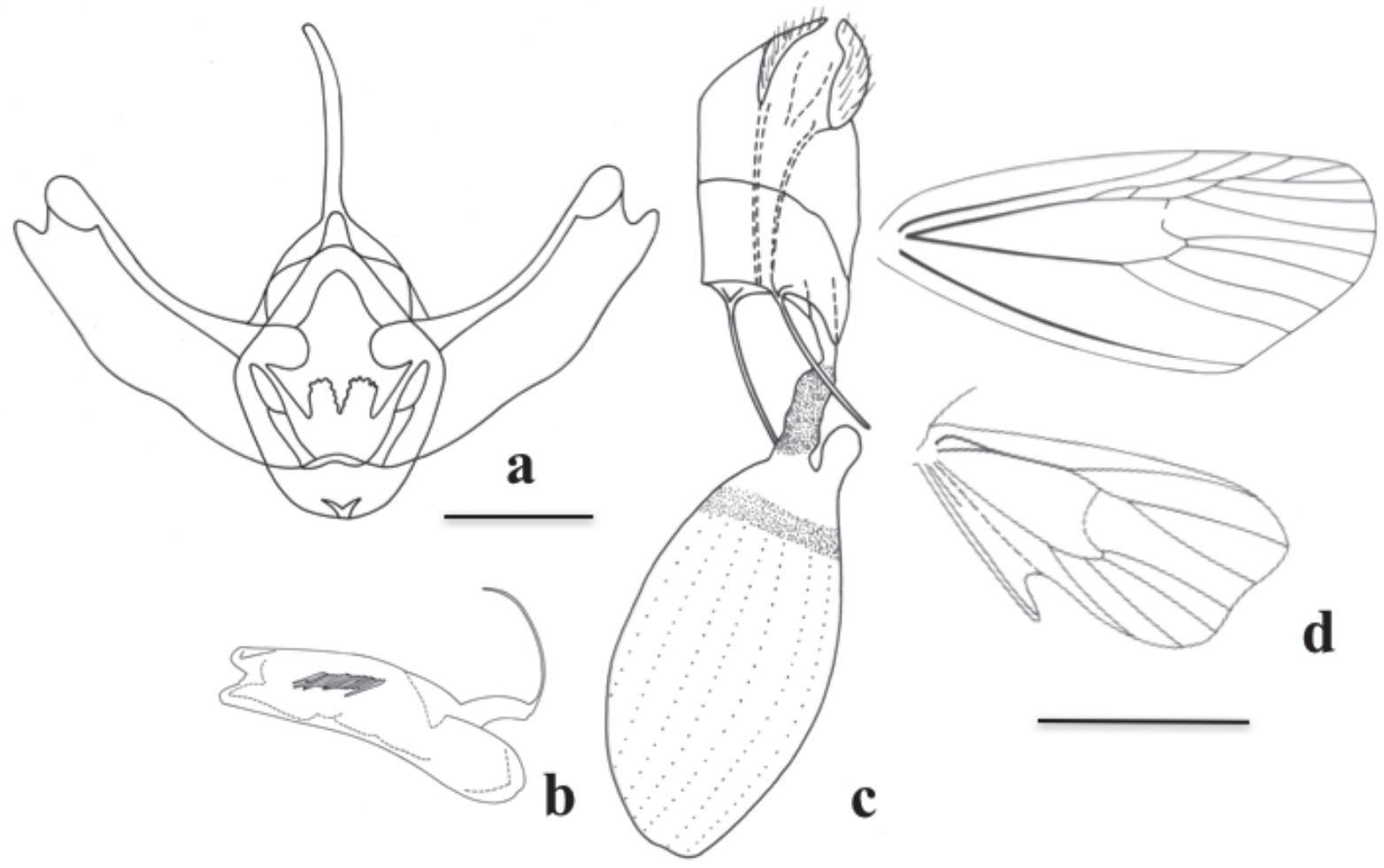

FIGURE 9. Genitalia and wing venation of Butleriana. a and b) male genitalia in ventral view and aedeagus in lateral view of $B$. oculata (Mabille), c) female genitalia in ventral view of B. fumosa (Butler), and d) male wing venation of B. fasciata (Butler). Genitalia scale 0.5 $\mathrm{mm}$, Wing scale $1 \mathrm{~cm}$. / Armaduras genitales y venación alar de Butleriana. a y b) genitalia del macho en vista ventral y aedeagus en vista lateral de B. oculata (Mabille), c) genitalia de la hembra en vista ventral de B. fumosa (Butler), y d) venación alar del macho de B. fasciata (Butler). Escala genitalia 0,5 mm, Escala alas $1 \mathrm{~cm}$.

Danielaparra Kemal \& Kocak, 2004

Daniela Parra, 1996:42

Danielaparra Kemal \& Kocak, 2004:4

Parraiella Özdikmen, 2008:185 n. syn.

TyPe Species. Daniela viridis Parra, 1996:42. By original designation.

\section{REDESCRIPTION}

The general appearance of the moth is shown in figure $4 \mathrm{~g}$ Medium sized moths, forewing length varies between 14 and $18 \mathrm{~mm}$.

Ciliate antennae on the male. Filiform on the female. Mottled forewings with black and green spots, on which the bands are highlighted due to their white color. White hindwings, distal spot present. Forewing venation: with two accessory cells. Hindwing venation: the Sc and Rs veins are free in the male, anastomosed in the female; Rs and $\mathrm{M}_{1}$ originate from the same point on the female, free in the male; the males have a lobe with two anal veins (Fig. 10d). Legs: tibial formula 0-2-4; male metathoracic tibia with hair pencil. Male abdomen has a sternal pouch.
Male genitalia (Figs. $10 \mathrm{a}-\mathrm{b}$ ). Uncus digitiform, reaches $1 / 2$ of the length of the valvae; sub rectangular valvae, with an indention in the apex region adjacent to the costal region; sacculus present, boot shaped; anellus sub quadrangular, with two half digitiform projections on the hind wall; pyramid shaped anellus process, made up of small spines; saccus vinculum quadrangular. Aedeagus sub equal along the valvae; wide sheath on the first third and inflated in the seminal duct area. Vesica composed of three thick spines and a group of microspines.

Female genitalia (Figs 10 c). Membranous corpus bursae, in a half-moon shape on the front portion. Back portion sclerotized and with grooves; sclerotized ductus bursae on its anterior region, coinciding with the end of the corpus, two times longer than wide; posterior apophyses two times longer than the anterior.

\section{DifFERENTIAL DiAGNosis}

Danielaparra, presents a very similar coloring to Triptalia and to the species Triptiloides esmeralda (Parra and Santo-Salas, 1992), but possesses a totally different genital structure in the male and female. The genus is unique in that the male has a 
sacculus (like Fueguina) but in a boot shape (autapormorphy), armed anellus process (like Arrayanaria) and the presence of a socius (like Llampidken); these combined characters were never present in other genera of the tribe. The sclerotization of the posterior region of the corpus bursae, which is strong and striated is highlighted in the female.

\section{DisTRIBUTION}

Endemic Chilean species, it is distributed in the following biogeographic provinces: Central Valley, Southern Andean Mountain Range, Pehuenar, Valdivian Forest, Aysen Mountain Range, Magellanic Interoceanic., Its most Northern record is Molina $\left(35^{\circ} \mathrm{S}\right)$ and the most Southern is Cerro Castillo $\left(51^{\circ} \mathrm{S}\right)$

\section{OBSERVATIONS}

This is one of the genus that, along with Butleriana, presents a wide range of distribution, principally found distributed in territories such as, sclerophyllous and temperate forests (Valdivian and Magallanic Rainforests).

In the phylogenetic analysis, this genus represents the sister group de Fueguina, even though there is not a clear synapomorphy that relates them. Probably, the presence of a sacculus arm is the character that establishes the relationship.

SPeCies InCluded

fragmentata (Dognin, 1906) (Rhopalodes) viridis (Parra, 1996) n. syn.

imbricaria (Felder \& Rogenhofer, 1875) comb. nov. (Lobophora)

$$
\text { laetaria Staudinger, 1899:90 (Lobophora) }
$$

Fueguina Parra, 1991

Fueguina Parra, 1991:165.

Type Species. Pachrophylla varians Butler, 1882:400. By original designation Parra, 1991:165.

\section{REDESCRIPTION}

The general appearance of the moths is shown in figures $4 \mathrm{~h}$ and $5 \mathrm{a}$. Small to medium sized moths, the forewing length varies between 13 and $21 \mathrm{~mm}$.

Head without ocelli; chaetosomata present; antennae filiform. Forewings have variable maculation. Forewing venation: with two accessory cells. Hindwing venation: Sc and Rs united by a transversal vein in the male, anastomosed in the female; Rs and $\mathrm{M}_{1}$ pedunculated in both sexes; hindwing lobe with two anal veins; $\mathrm{M}_{3}$ and $\mathrm{Cu}_{1}$ are generally pedunculated (Fig. 11d). Male legs with a tuft of scales on the internal apex of the metathoracic femur, metathoracic tibias with hair pencil. Tibial formula 0-2-4. Male's abdomen has a sternal pouch.
Male genitalia (Figs. 11 a-b). Uncus thin and small, acute apex, digitiform or short or thick; socius and gnathos absent; valvae two times longer than wide, forked apex (cucullus region) leaving a deep, round cavity; sacculus armed with a spiny process, thick and finishing at a point; quadrangular or sub-rectangular anellus with two central lobes on the hind edge; sacculus vinculum quadrangular or sub-rectangular. Aedeagus 9 times longer than wide and sub equal along the valvae; seminal duct comes from the pouch's central region; vesica unarmed or armed with a group of spines.

Female genitalia (Fig. 11 c). Corpus bursae sub-piriform, membranous, one third of the front of the internal surface and dorsal ventral wall covered by microspines; the seminal duct comes from a protuberance on the cestum; the cestum is longer than it is wide, it takes up approximately $1 / 3$ of the length of the ductus bursae; membranous colliculum; posterior apophyses two times longer than the anterior.

\section{DiFFERENTIAL DIAGNOSIS}

The genus is made up of three species that vary notably in the type of maculation, from grayish colors to pink and light brown. The $\mathrm{M}_{3}$ and $\mathrm{Cu}_{1}$ veins of the male's hindwing are pedunculated at least from the base or free; lobe with two anal veins. Male genitalia with spiny sacculus and a deep indention on the cucullus region (autoapomorphy). These characteristics of the genital armature, allow this taxon to be easily separated from the rest of the components of the tribe.

\section{DisTRIBUTION}

Endemic genus in Chile, it is distributed in the following biogeographic provinces: Northern Valdivian Forest, Pehuenar, Valdivian Forest, Valdivian Mountain Range, Magellanic Interoceanic, and Southern Pacific. F. varians is the most widely distributed species and along with $F$. magallanica is the one that arrives the farthest South.

\section{OBSERVATIONS}

The general appearance of the moths is very close to Pachrophylla, but a more detailed analysis allows these species to be separated into a different genus (Parra, 1991). The deep indention of the apex of the valvae is the character that defines this genus and clearly separates it from Pachrophylla. In the phylogenetic analysis, a common branch is formed with Danielaparra because of the presence of an arm on the sacculus.

SPECIES INCLUDED

celovalva Parra, 1991

limnetes (Prout, 1923) (Hoplosauris)

magallanica Parra, 1996

varians (Butler, 1882) (Pachrophylla) stenopterata Mabille, 1885 (Lobophora) 

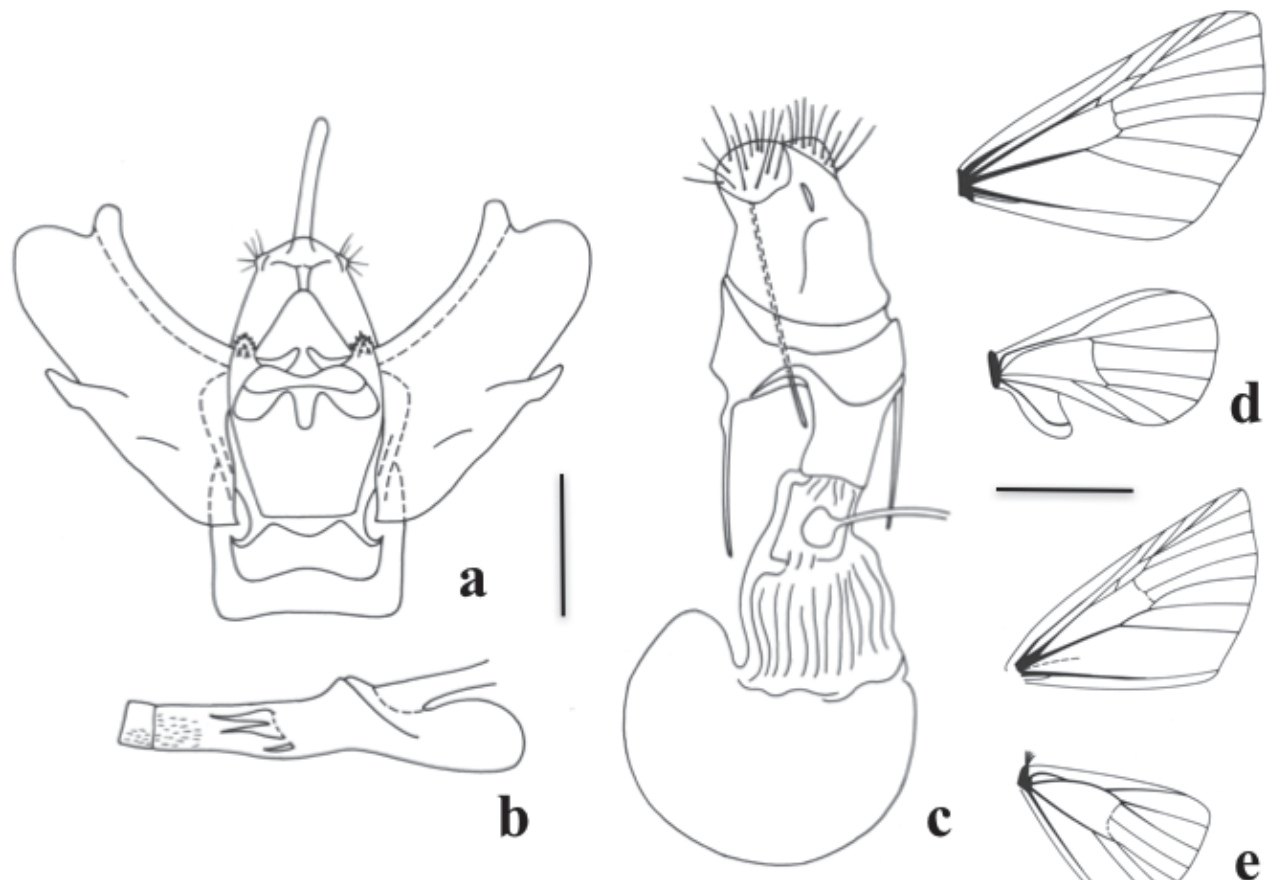

C

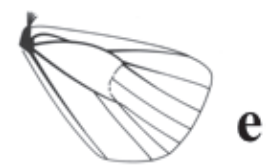

FIGURE 10. Genitalia and wing venation of Danielaparra fragmentata (Dognin) a) male genitalia in ventral view, b) aedeagus in lateral view, c) female genitalia in ventral view, d y e) male and female wing venation. Genitalia scale $0.5 \mathrm{~mm}$, Wing scale $1 \mathrm{~cm}$. / Armaduras genitales y venación alar de Danielaparra fragmentata (Dognin) a) genitalia del macho en vista ventral, b) aedeagus en vista lateral, c) genitalia de la hembra en vista ventral, d y e) venación alas del macho y hembra. Escala genitalia 0,5 mm, Escala alas $1 \mathrm{~cm}$.
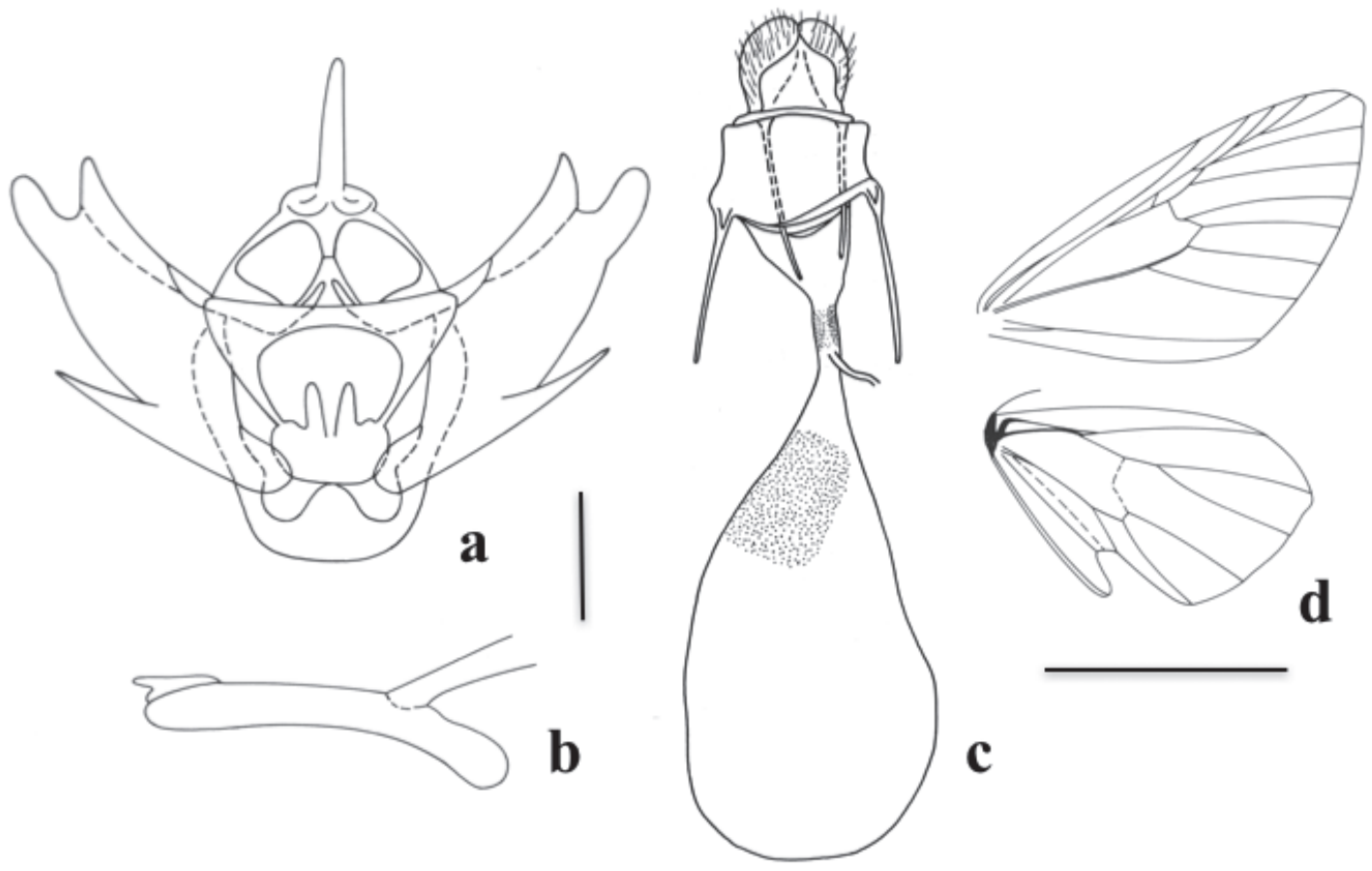

FIGURE 11. Genitalia and wing venation of Fueguina. a and b) male genitalia in ventral view and aedeagus in lateral view of $F$. magallanica Parra, c) female genitalia in ventral view of $F$. varians (Butler), and) male wing venation of $F$. magallanica Parra. Genitalia scale 0.5 mm, Wing scale $1 \mathrm{~cm}$. / Armaduras genitales y venación alar de Fueguina. a y b) genitalia del macho en vista ventral y aedeagus en vista lateral de F. magallanica Parra, c) genitalia de la hembra en vista ventral de $F$. varians (Butler), y d) venación alar del macho de $F$. magallanica Parra. Escala genitalia 0,5 mm, Escala alas $1 \mathrm{~cm}$. 


\section{Hoplosauris Butler, 1882}

Notholoba Warren, 1908:103.

Type Species Hoplosauris heliconoides Butler, 1882:399. By original designation. Notholoba schausi Warren, 1908:103. By original designation

\section{REDESCRIPTION}

The general appearance of the moths is shown in figures $5 b$. Filiform antennae in males and females; thorax and abdomen with brown scales that vary in reddish, orange, and greenish tones; forewings with a distal spot on the dorsal surface. On the anal margin of the male's hindwings a concave or convex hairy vesicle is found present or only with hairy scales.

Male genitalia (Fig. 12 a-b). Subrectangular or subtriangular valvae with a coremata located on the subapical area; tubular aedeagus, vesica armed with one or two groups of spines.

Female genitalia (Fig. 12 c). Spherical or globous corpus bursae with microspines on the surface; membranous sterigma.

\section{DiFFERENTIAL DIAGNOSIS}

In the male, the anal margin of Hoplosauris' hindwings are reduced by a tuft of hair or the presence of a small vesicle or lappet; on their genitalia a coremata is found in the subapical region of the valvae, which are subtriangular or sub rectangular; the aedeagus' vesical has one or two groups of compact spines. On the female, the corpus bursae is spherical or globular, its internal surface has microspines arranged in different regions. The synapmorphies that sustain the genera are: filiform male antennae; distal spot on the forewings; hairy scales on the anal margin of the male's hindwings; microspines on the internal surface of the corpus bursae; membranous sterigma; swollen uncus base; hairy uncus; coremata in the subapical region of the valvae.

\section{DisTRIBUTION}

Hoplosauris is distributed between $33^{\circ} \mathrm{S}$ and $52^{\circ} \mathrm{S}$ between the Valparaiso and Magellan provinces, Chile. It is distributed in the following biogeographic provinces: Coquimbo Desert, Central Andean Cordillera, Central Coastal Cordillera, Southern Andean Mountain Range, Northern Valdivian Forest, Pehuenar, Valdivian Forest and Valdivian Mountain Range (Argentinian and Chilean side), Magellanic Interoceanic.

SPECIES INCLUDED

granitata (Fletcher, 1953) (Physoloba)

heliconoides Butler, 1882

multivirgulata Mabille, 1885 (Larentia)

indistincta (Butler, 1882) (Amathia)

viridularia Dognin, 1906 (Rhopalodes)

macarenae Parra, 2009

mabillei Parra, 2009

pachrophylloides Parra, 2009

schausi (Warren, 1908) (Notholoba)

valeria Butler, 1893
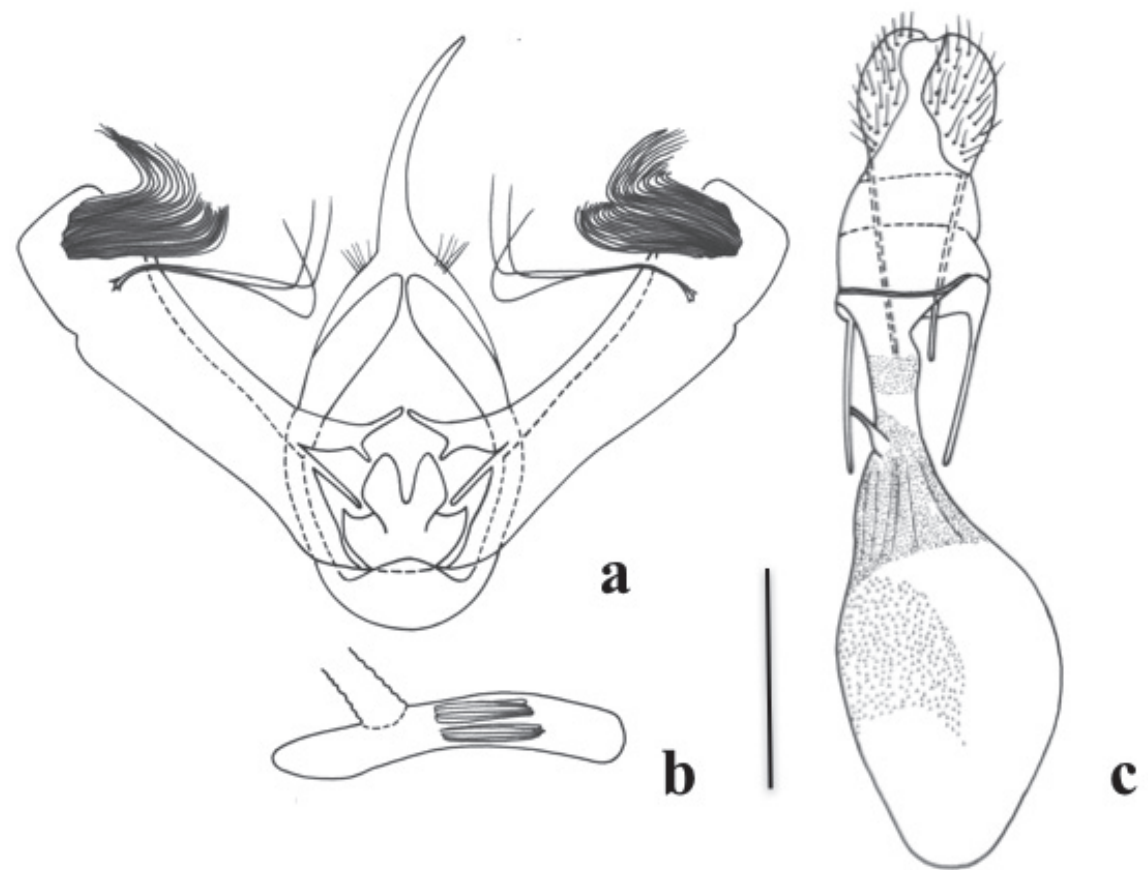

FIGURE 12. Genitalia and wing venation of Hoplosauris granitata (Fletcher). a) male genitalia in ventral view, b) aedeagus in lateral view, and c) female genitalia in ventral view. Genitalia scale $0.5 \mathrm{~mm}$, Wing scale $1 \mathrm{~cm}$. / Armaduras genitales y venación alar de Hoplosauris granitata (Fletcher). a) genitalia del macho en vista ventral, b) aedeagus en vista lateral, y c) genitalia de la hembra en vista ventral. Escala genitalia $0,5 \mathrm{~mm}$, Escala alas $1 \mathrm{~cm}$. 


\section{Lagynopteryx Berg, 1883}

Lagynopteryx Berg, 1883:166.

Lagynopteryx Berg. Bartlett-Calvert, 1886:338; Fletcher 1953: 379; Angulo \& Casanueva, 1981:29.

Toxopaltes Warren, 1894:398. syn. nov.

Type Species Lagynopteryx valdiviana Berg, 1883. Designated by Fletcher, 1979:112.

Tomopteryx botulata Felder \& Rogenhofer, 1875. Designated as type species of Toxopaltes by Warren, 1894:398.

\section{REDESCRIPTION}

The moth's general appearance is shown in figures $5 \mathrm{c}$-e. Small sized moths with the forewing length varying between 9 and $11 \mathrm{~mm}$.

Head without ocelli; chaetosemata present; antenna rhopalocerus like; labial palp and the head are unicolored, middle segment is four times longer than the distal. Forewing venation: with two accessory cells. Hindwing venation: In the male, the Sc and Rs veins are separated, Rs and $M_{1}$ pedunculated, with a $\mathrm{Cu}$ and an $\mathrm{A}$ vein. In the female, the $\mathrm{Sc}$ and Rs veins are anastomosed, Rs and $\mathrm{M}_{1}$ pedunculated, with two $\mathrm{Cu}$ veins and one $\mathrm{A}$. The forewings are light brown alternating with dark brown areas; bands are present. The male's hindwings are small, white, and slightly transparent, the females are ash-gray. Male hindwing with a tail between the Rs and $M_{1}$ veins and a small lobe (vesicle or flap) without veins (Fig. 13 d). Legs: tibial formula 0-2-4; male metathoracic tibia with hair pencil. The male's abdomen has a sternal pouch (Figs. 2b and 13e) and a coremata (Fig. 2c).

Male genitalia (Figs. 13 a-b). Costal region of the valvae with a projection ending in two points, cucullus region with thick bristles.

Female genitalia (Fig. 13 c). Membranous, elongated corpus bursae; tubular ductus bursae, very long and membranous.

DifFERENTIAL DIAGNOSIS

This genus is unique within the Trichopterygini, since the male's hindwings have reduced venation, a small lobe ("flap") and a tail between the Rs and $\mathrm{M}_{1}$ veins (both autoapomorphies). Male genitalia, costa with a projection ending in two points and valvae with bristles on the cucullus region. Female genitalia, membranous corpus bursae, tubular ductus bursae, ten times longer than wide.

\section{DisTRIBUTION}

Endemic species to the study zone, it is widely distributed in temperate and cold temperate forest areas, being found in the Argentinian territory adjacent to the Andes Mountain Range. It is distributed in the following biogeographic provinces: Southern Andean Mountain Range, Northern Valdivian Forest, Pehuenar, Valdivian Forest and Valdivian Mountain Range (Argentinian side); its most Northern record is Las Trancas, Chillán Mountain Range $\left(36^{\circ} 20^{\prime} \mathrm{S}\right)$ and the most Southern, Valdivia $\left(40^{\circ} \mathrm{S}\right)$.

OBSERVATIONS

The valid genus of this species, by priority order, corresponds to that described by Berg (1883), Lagynopteryx.

Warren (1894) created the genus, Toxopaltes for two species described as Tomopteryx botulata and T. laciniosa for Chile by Felder and Rogenhofer (1875). The type species of Lagnopteryx was not revised, but basing it on Fletcher (1953), it was confirmed that the valid genus was that described by Berg. The analysis of the different structures allowed us to conclude that Toxopaltes is a junior synonym of Lagynopteryx. The species described as Tomopteryx botulata, T. laciniosa, and Docirava chilensis do not correspond to the type species of the genera that were initially included.

In the phylogenetic analysis Lagynopteryx appears associated with very dissimilar genera. It is probable that with an adequate knowledge of the immature states of those genera, the grouping would improve.

Lagynopteryx botulata (Felder \& Rogenhofer, 1875)

(Figs. 2b-c, 5c-e and 13 a-e)

Tomopteryx botulata Felder \& Rogenhofer, 1875: pl. 131, fig. 18. Bartlett-Calvert, 1886:338; Fletcher 1953:379; Angulo \& Casanueva, 1981:29 (Lagynopteryx)

Tomopteryx laciniosa Felder \& Rogenhofer, 1875: pl. 131, fig. 21; Bartlett-Calvert, 1886:338; Angulo \& Casanueva, 1981: 29. (Lagynopteryx) syn. nov.

Docirava chilensis Butler, 1882:420; Bartlett-Calvert, 1886: 341; Angulo \& Casanueva, 1981:27 syn. nov.

Lagynopteryx valdiviana Berg, 1883:166; Bartlett-Calvert, 1886:338; Fletcher, 1953:379; Angulo \& Casanueva, 1981:29.

TYPE SPECIMENS

Tomopteryx botulata. Holotype, male, Chile, BMNH (Examined).

Tomopteryx laciniosa. Holotype, male, Chile, BMNH (Examined).

Docirava chilensis. Holotype, male, Chile, BMNH (Examined).

Lagynopteryx valdiviana. Holotype, male, Valdivia, MACNBR (Not examined).

\section{REDESCRIPTION}

General aspect of the insect as shown in figures $5 c, d$ and e. Male (Fig. $5 \mathrm{c}$ and e). The forewing dorsal surface has dark and light brown stripes; dark brown basal band, fine and lineal; wavy antemedial band, dark brown; white post medial band, with a subangular projection between the 
external margin; dark brown stripe between the ante and post medial bands, with a dark brown distal spot; white and angular adterminal band; light brown and dark brown stripe between the post and adterminal bands, the darkest area is wide close to the costal region and the anal margin, between $M_{1}$ and $M_{2}$ it is very narrow; the terminal band is dark brown, interrupted by the veins; light brown external margin stripe. Light brown ventral surface, light spotting. Hindwings: dorsal and ventral surfaces are yellowish-white all around their edges, transparent in the middle area, where there is a structure that seems to produce sound (Fig. 13d), with a tail and a small lobe (vesicle or flap) on the male; on the middle region of the anal margin there is a group of dark brown scales.

Female (Fig. 5d). Like the male, but with darker bands and stripes, contrasting with the white color that defines them; ashy gray hindwings with no tail, not even a lobe nor a structure to produce sound; no hair pencil on the metathoracic tibia and without sternal pouch of the abdomen.

Male genitalia (Figs. 13 a-b). Simple uncus, slightly thick; absent socius and gnathos; anellus sub rectangular on their front portion and subtriangular on the back; simple valvae, two times longer than wide, armed costa close to the apex, arm finishes in two points; cucullus with a small indention and with 4 bristles directed towards the internal region; normal sacculus; subtriangular saccus-vinculum, round frontal margin. Aedeagus 1.5 times longer than the valvae; vesica with two spines.

Female genitalia (Fig. 13c). Elongated corpus bursae, membranous, shorter than the posterior apophyses; absent signum; ductus bursae, membranous, 10 times longer than wide; posterior apophyses two times longer than the anterior ones.

Length of the hindwings: male, 9-10 mm; female $11 \mathrm{~mm}$.

DifFERENTIAL DiAGNosis. Like that of the genus description

Distribution. Like that of the genus description

FLIGHT PERIOD

Species captured from November to February. Voucher labels indicating data between September and December are not considered due to the ambiguity of the capture information.

\section{OBSERVATIONS}

The type material of practically all the species included here was revised. Comparing the specimens and their genital armature allows us to conclude that T. lacinosa and $D$. chilensis are junior synonyms of $L$. botulata. L. valdiviana is included here as a synonym based on Fletcher's study (1953), however, the type specimen of this species was not examined.
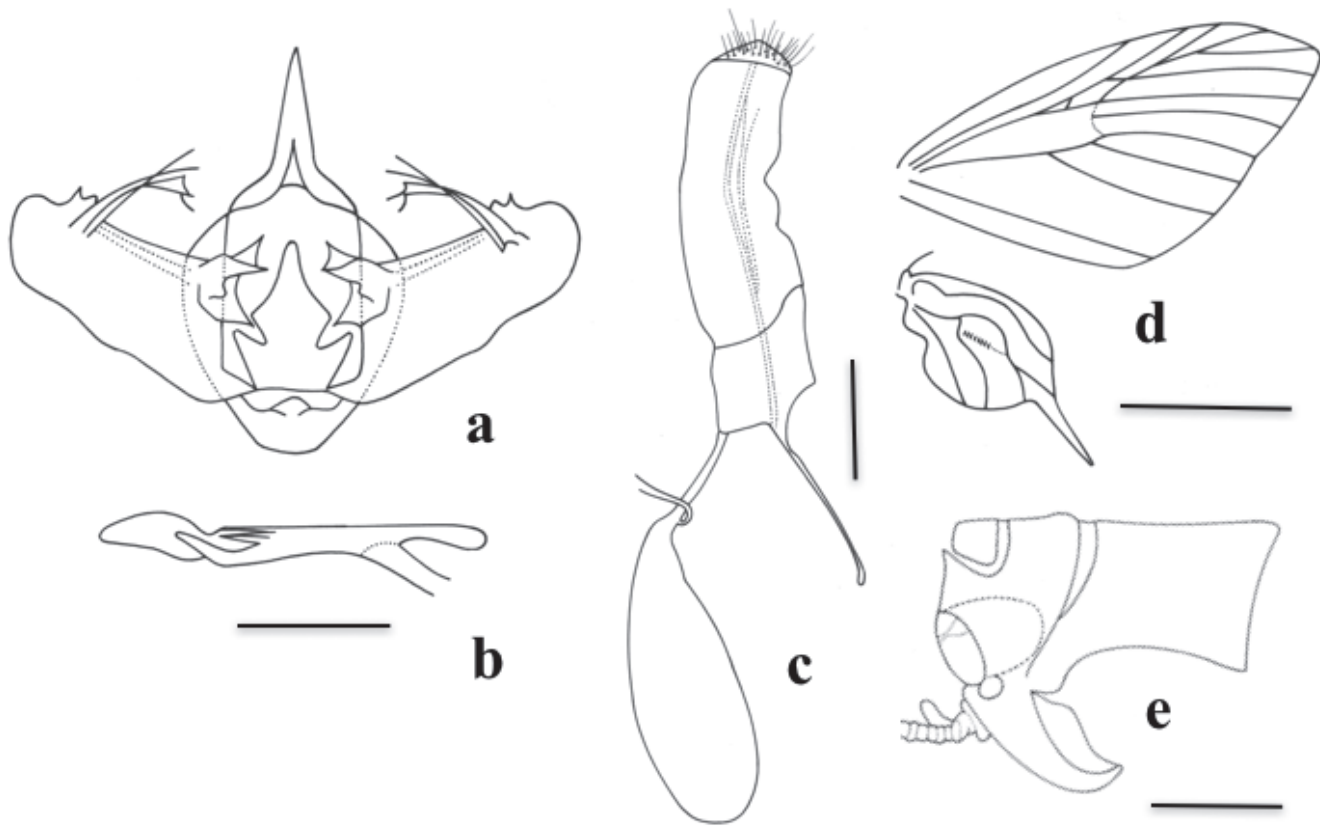

FIgURE 13. Genitalia and wing venation of Lagynopteryx botulata (Felder \& Rogenhofer). / a) male genitalia in ventral view, b) aedeagus in lateral view, c) female genitalia in ventral view, and d) Sternal pouch in male abdomen. Genitalia scale $0.5 \mathrm{~mm}$, Wing scale $1 \mathrm{~cm}$. $/$ Armaduras genitales y venación alar de Lagynopteryx botulata (Felder \& Rogenhofer). a) genitalia del macho en vista ventral, b) aedeagus en vista lateral, c) genitalia de la hembra en vista ventral, d) venación alar del macho, y d) vista lateral del abdomen de un macho en donde se muestra el saco esternal. Escala genitalia $0,5 \mathrm{~mm}$, Escala alas $1 \mathrm{~cm}$. 
The wing pattern of this species is practically similar in all the specimens, it only varies in color. So, in some specimens the bands are dark brown and the white areas are less obvious; in others, the stripe between the ante- and postmedial bands is light brown (like f. chilensis and f. laciniosa); or the light brown color is replaced by a coppery brown and the adterminal band is not obvious (L. botulata).

The vein reduction and especially, the presence of a structure between the $\mathrm{R}$ and $\mathrm{M}$ veins (translucent area) that seems to allow the production of sound are notable in the male. It will require further investigation of this structure to better understand how it works, it has not been identified as morphologic element that functions as a scraper.

Material eXamined (71 males, 29 females)

CHILE: 1 male, Holotype (T. botulata), Chile; 1 male, Holotype (T. laciniosa); 1 male, Holotype (D. chilensis), Chili (BMNH). Las Trancas, Chillán mountain range (Ñuble), Trap UV coll.: 3 males, 8-I-1996, 5 males and 2 females, 11-I-1996, 5 males and 3 females, 12-I-1996, 1 male and 5 females, 16-I-1996, 5 males and 4 females, 19-I1996 (UCCC-MZUC). Concepción, Trap UV coll.: 1 male, 22-XI-1960, 3 males, 28-XI-1960, 1 male, 30-XI-1960, 8 males 3 females, 6-XII-1960, 7 males, 5-XII-1960, 4 males and 3 females, 7-XII-1960, 2 males and 1 female, 10-XII1960, 1 male, 10-I-1961, 1 female, 7-XII-1961, 1 male, 2-I-1962, 1 male, 3-I-1962, 1 male, 16-I-1962, 1 male, 22I-1962 (UCCC-MZUC). 1 male, Pemehue, IX-XII-1896; 1 male, Araucanía, I-1892 (MNHN). 2 males, Lonquimay, Cautín, II-1951 (UCCC-MZUC). Valdivia: 2 males, 20-XI1986, 2 females, 30-XI-1986, 1 female and 1 male, 2-XII1986 (UCCC-MZUC). 1 male and 1 female, Pucoihue, XII1988 (UCCC-MZUC). ARGENTINA: Pucará, P. N. Lanín, Neuquén, Schajovskoi coll.: 12 males, 12-I-1951, 2 males, I-1951, 2 females, II-1951, 1 female, I-1951 (IML). San Martín de los Andes, Schajovskoi coll.: 2 males, II-1950 (IML).

Bibliographic citations. CHILE: Valdivia (Berg, 1883).

Llampidken Parra \& Santos-Salas, 1992

Llampidken Parra \& Santos-Salas, 1992b:151

Type Species Llampidken valdiviana Parra \& Santos-Salas, 1992b:152. By original designation.

\section{REDESCRIPTION}

The general appearance of the moth is shown in figure $5 \mathrm{f}$. Medium-sized moths, the forewing length ranges from 15$16 \mathrm{~mm}$.

Head without ocelli; rhopalocerus-like antennae in the male and simple in the female; labial palp, mid-segment 4 times longer than the distal segment. Dark brown forewings with a slight green color. Hindwings white to light brown. Forewing venation: with two accessory cells. Hindwing venation: Sc and Rs veins anastomosed in both sexes; Rs and $\mathrm{M}_{1}$ pedunculated in both sexes; male lobe without an anal vein (Fig. 14d). Legs: tibial formula 0-2-4; femur and metathoracic tibia, in the male, with a tuft of scales and hair pencil, respectively. Male's abdomen has a sternal pouch.

Male genitalia (Figs. $14 \mathrm{a}-\mathrm{b}$ ). Uncus digitiform, reaches $1 / 2$ the length of the valvae; dense socius with a forked apex; gnathos digitiform subequal in size to the uncus, but thicker; valvae $1 / 3$ longer than wide, neckline apex, but with a very developed triangular valvula; costal arm, capitiform; sacculus with a small projection and on its internal area a group of small spines; sub-quadrangular anellus, with three hind projections, forked sacculus-vinculum. Aedeagus slightly longer than the valvae; vesica with odontoid cornuti with 3 apical points.

Female genitalia (Figs. 14c). Corpus bursae globous, membranous, small; large ductus bursae, slightly longer than wide; the cestum occupies $1 / 3$ of the length of the ductus; membranous colliculum; posterior apophyses 6 times longer than the anterior.

\section{DifFERENTIAL DIAGNOSIS}

This genus is distinguished from all the other members of the tribe because the hindwing lobe on the male does not have veins (autoapomorphy). Male genitalia, gnathos and socius present (the presence of the gnathos constitutes an autoapomorphy for the genus), armed sacculus, vesica armed by an odontoid cornuti. Female genitalia, posterior apophyses 6 times longer than the anterior.

\section{DistRiBUTION}

The species and genus are endemic to Chile, they are distributed in the following biogeographic provinces: Northern Valdivian Forest and Valdivian Forest; their most Northern record is the Araucanía Region and the most Southern is Valdivia $\left(40^{\circ} \mathrm{S}\right)$. The species is only distributed in temperate forests in the South of Chile.

\section{OBSERVATIONS}

According to the phylogenetic analysis, this genus is the closest to Tatosoma; its relation is based on the process or costal arm in the valvae of the male's genitalia.

SpeCIES INCLUDED

moesta (Butler, 1882) comb. nov. (Hoplosauris) valdiviana Parra \& Santos-Salas, 1992b. syn. nov. 

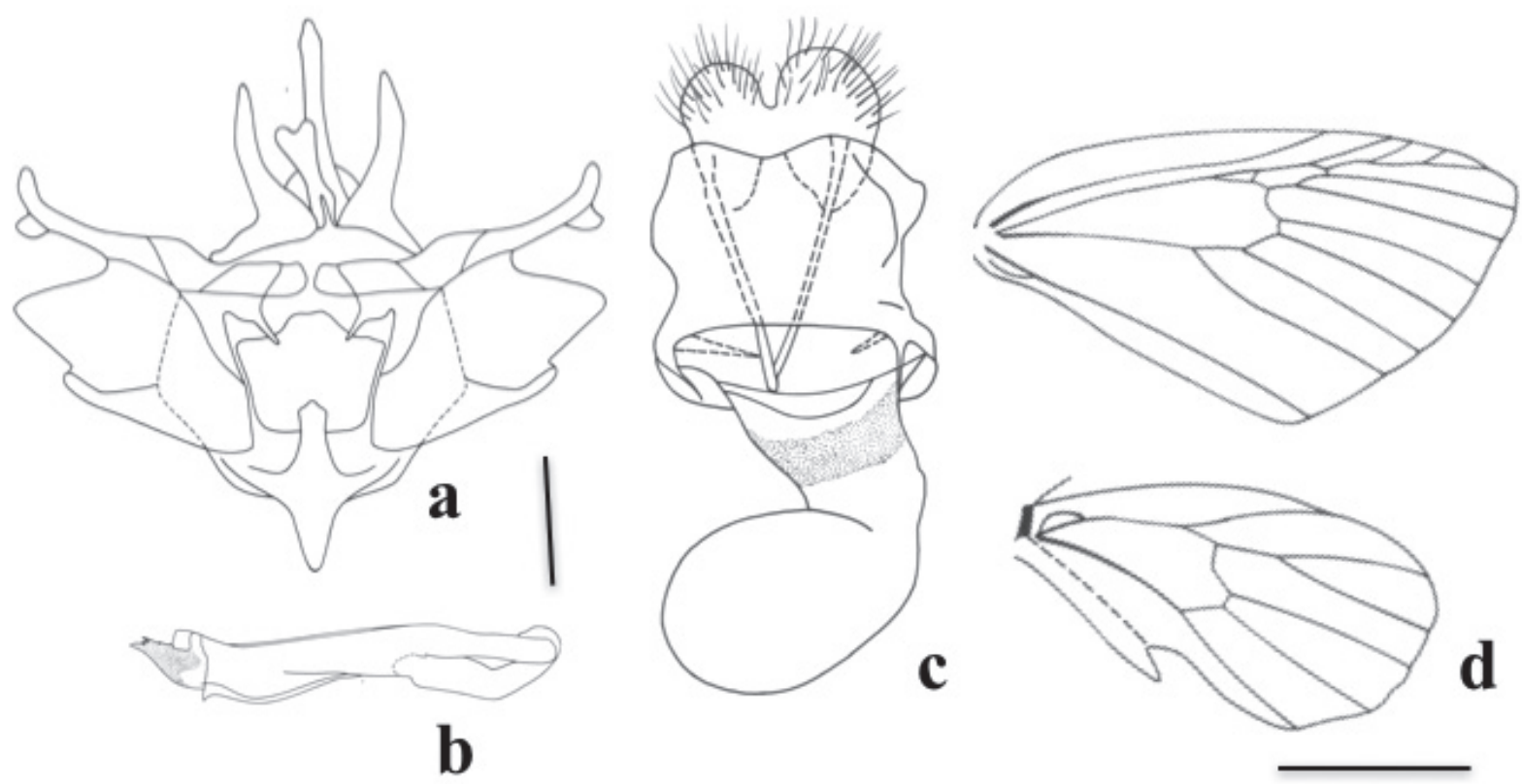

FIGURE 14. Genitalia and wing venation of Llampidken moesta (Butler). a) male genitalia in ventral view, b) aedeagus in lateral view, and c) male wing venation. Genitalia scale $0.5 \mathrm{~mm}$, Wing scale $1 \mathrm{~cm}$. / Armaduras genitales y venación alar de Llampidken moesta (Butler). a) genitalia del macho en vista ventral, b) aedeagus en vista lateral, y c) venación alar del macho. Escala genitalia 0,5 mm, Escala alas $1 \mathrm{~cm}$.

Pachrophylla Blanchard, 1852

Pachrophylla Blanchard, 1852:96

Bacillogaster Blanchard, 1852:99.

Type Species Pachrophylla linearia Blanchard, 1852:97. By monotypy.

\section{REDESCRIPTION}

The general appearance of the moth is shown is the figure $5 \mathrm{~g}$. Big moths, with narrow wings, the length of the forewing varies between 19 and $20 \mathrm{~mm}$.

Head without ocelli; chaetosemata present; filiform antennae; light brown thorax and abdomen. Light brown anterior wings, with a black stripe close to the anal margin. The male has white posterior wings, with a lobe that is folded or overlapped, longer than it is wide, and reaches $1 / 3$ of the length of the wing. Forewing venation: two accessory cells. Hindwing venation: the Rs and Sc veins are free, only united by a short transversal vein at the end of the discal cell, anastomosed in the female; Rs and $M_{1}$ are pedunculated; lobe with two anal veins (Fig. 15d). Legs: tibial formula $0-2-4$, male metathoracic femur and tibia with a tuft of scales and hair pencil, respectively. Male abdomen with a sternal pouch.

Male genitalia (Figs. 15 a-b). Uncus thin, strong, half the length of the valvae, extremely acute; absent socius and gnathos; valvae approximately 4.5 times longer than their maximum width, apically sinuous margin; sacculus normal; anellus subquadrangular with two lateral projections; forked saccus-vinculum, central projection with rounded to blunt margin. Aedeagus about $20 \%$ shorter than the valvae, 7 times longer than wide; seminal duct comes from the mid region of the sheath; vesica armed by a group of 4 spines.

Female genitalia (Fig. 15c). Globous corpus bursae, with a thick and short appendix, organized towards the right side in the anterior region; the area adjacent to the ductus bursae has a sub anular stripe, spiny, prolonged towards the extreme anterior in a series of striations; ductus bursae 4.2 times longer than wide; anterior apophyses $20 \%$ shorter than the posterior, both long and thin.

\section{DifFERENTIAL DIAGNOSIS}

This genus is distinguished from the others by its long and narrow wings, from light brown to dark brown; both pairs of spurs on the metathoracic tibias are reduced (autoapomorphy) (Fig. 15e). Male genitalia, long and narrow valvae; cucullus region without an indention, sinuous; armed aedeagus. Female genitalia, globous corpus bursae, with a thick and short appendix organized towards the right side in the anterior region.

\section{Distribution}

The genus and species are endemic to Chile, they are distributed in the following biogeographic provinces: Coquimbo Desert, Central Valley, Valdivian Forest, Northern Valdivian Forest (Precordillera Region) and Pehuenar, its most Northern record is Viña del Mar $\left(33^{\circ} \mathrm{S}\right)$ and the most Southern Termas de Rio Blanco, Cautín (38 $30 \mathrm{~S}$ ). 


\section{OBSERVATIONS}

In the first revisions, many species were assigned to this genus for the similarity of the maculation pattern on the anterior wings, for the external form (appearance) and for the presence of the lobe on the posterior wings of the male. The analysis of the male genital explains that this genus is monotypic but is closely related to the other taxa described here.

SPECIES INCLUDED

linearia Blanchard, 1852.

Parapachrophylla Parra, 1991

Parapachrophylla Parra, 1991:177.

Type SPecies Parapachrophylla claudiae Parra, 1991:180. By original designation.

\section{REDESCRIPTION}

The general appearance of the moths is shown in the figures 6 a-d. Small and medium-sized moths, the length of the forewing varies between 13 and $18 \mathrm{~mm}$.

Head without ocelli; chaetosomata present; antennae filiform; dark brown to light brown thorax and abdomen. Dark or light brown anterior wings, bands are present. White hindwings, in the male with a lobe overlapping the wing, thin, subtriangular that reaches $1 / 2$ the wing length. Forewing venation: with two accessory cells. Hindwing venation: Sc and Rs veins united by a small transversal vein in the posterior end of the cell; Rs and $M_{1}$ come from the same point or pedunculated; lobe with two anal veins (Fig. 16e). Legs: tibial formula 0-2-4; male metathoracic tibia with hair pencil. Male abdomen with sternal pouch.

Male genitalia (Figs. 16 a-c). Valvae with an apical indention, 4-5 times longer than wide; costal margin with a palpebral form appendix; subtriangular saccus vinculum; aedeagus has an armed vesica.

Female genitalia. Like the female from $P$. michelleae sp. nov.

DifFERENTIAL DiAgNosis

This genus differs from the others because the wings are narrow (like Pachrophylla), long, or short; the wing color varies from dark to light brown, the surface could be homogeneous or with motley spots. The male genitalia have a palpebral form appendix on the costal margin of the valvae (autoapormorphy). Distinguished from Pachrophylla for having developed middle spurs of the metathoracic tibia (Fig. 16f), an indention on the apical margin of the valvae and on the palpebral form appendix of their costal margin.

DisTRIBUTION

Endemic genus in Chile, it is found distributed in the following biogeographic provinces: Coquimbo Desert, Central Valley, Southern Andean Mountain Range and Valdivian Forest. $P$. claudiae has a relatively wide distribution, whereas $P$. celovalva is only found in two places.

\section{OBSERVATIONS}

The species of this genus are very similar to genera Butleriana and Pachrophylla in relation to maculation, but are clearly differentiated by the morphology of the male and female genitalia.

Parapachrophylla michelleae Parra, sp. nov. (Figs. 6 c-d and 16 a-d)

Material Type. Holotype, 1 male, Los Queñes, in the town of Teno, 3502`54 `S 70³7`07` O, 1060 m.s.n.m, 24-05-2012, Maule Region, F. Urra coll; Alotype, 1 female, La Mina, 9-08-1997, R. Badilla coll.; Paratypes: 1 female, La Mina, 9-08-1997, R. Badilla coll., 1 female, La Obra, Santiago, 16-04-1953 (UCCC-MZUC).

DiAgnosis. The species presents a characteristic maculation pattern on the forewings that easily distinguishes it from the rest of the species of the genus, this is a dark brown band that goes from the base of the wing to the external margin of the apical region of the forewings. P. michelleae sp. nov. is different from $P$. caliginosa and $P$. claudiae in that the juxta is reduced to two subtriangular parts that diverge from its base, in addition, $P$. maulina sp. nov. has a low neckline in the ventral margin of the valvae in the subapical region, giving it the appearance of being semi strangulated.

Male. General appearance is like it is shown in the figure 6c. Forewings: grayish to light brown dorsal surface, mottled with slightly darker spots, highlighting a dark brown band or stripe that crosses the whole wing from its base to the apex. The region between the antemedial and post medial bands is evident because of its dark brown color, therefore the bands stand out due to their lighter color. The ventral surface is similar to the dorsal, the colors are much softer and have a certain gray tone. Hindwings: lobe present, dorsal and ventral surface are grayish-brown with a light brown external margin.

Female. Similar to the male, but the hindwings don't have a lobe (Fig. 6d).

Forewing length: male, $17 \mathrm{~mm}$ (1); female, 16 to $19 \mathrm{~mm}$ (3)

Male genitalia (Figs. 16 a-c). Uncus thin and strong, acute end, $1 / 3$ the length of the valvae, reduced socius; valvae 4 or 5 times longer than wide, valvula region with a small indention, costal region (on the $1 / 5$ posterior) with a palpebral form appendix folded towards the internal face of the valve, a third of the posterior valvae semi strangulated; juxta reduced to two 

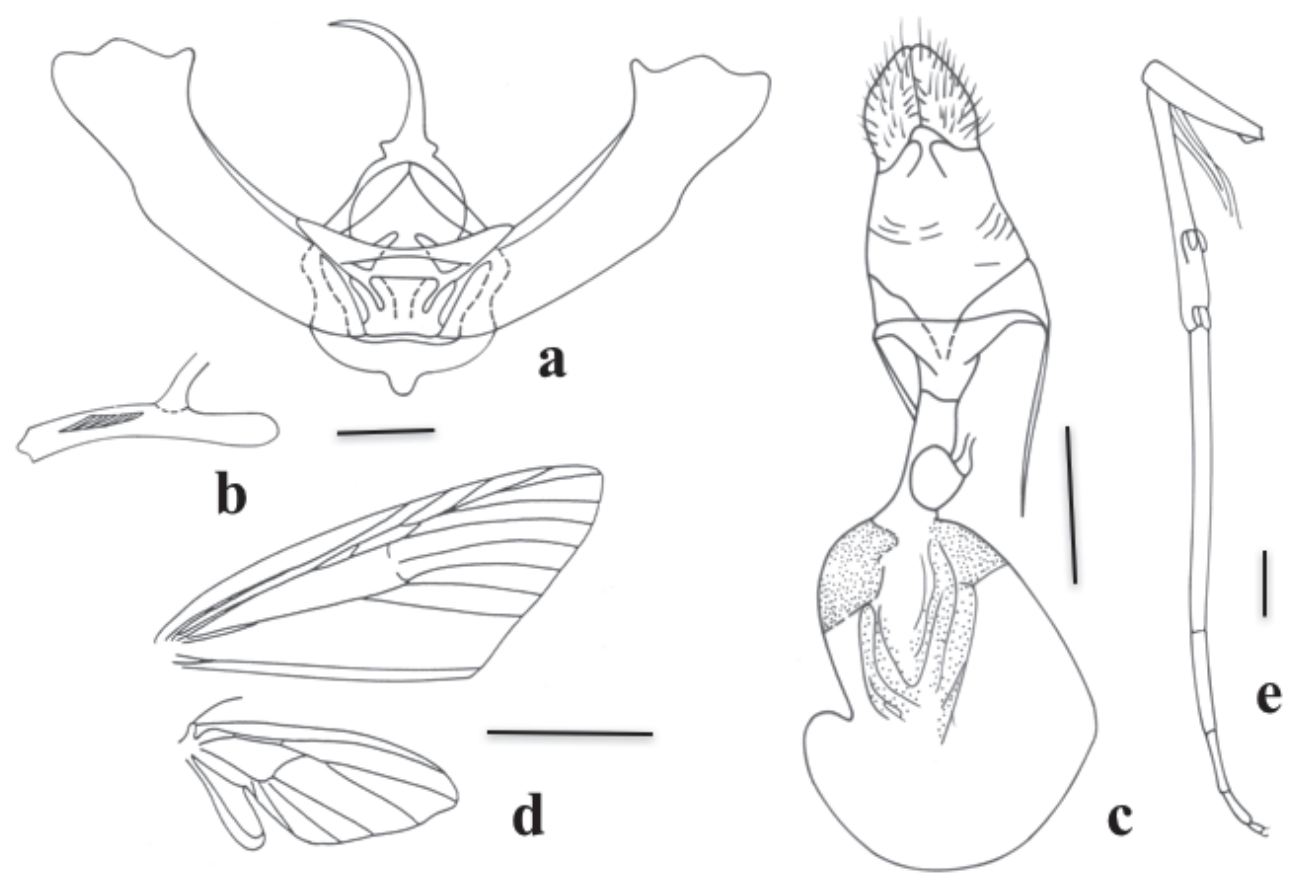

FIGURE 15. Genitalia, metathoracic leg and wing venation of Pachrophylla linearia Blanchard. a) male genitalia in ventral view, b) aedeagus in lateral view, c) female genitalia in ventral view, d) male wing venation, and e) metathoracic leg. Genitalia scale $0.5 \mathrm{~mm}$, Wing scale 1 $\mathrm{cm}$, Leg scale $0.5 \mathrm{~mm}$. / Armaduras genitales, pata metatorácica y venación alar de Pachrophylla linearia Blanchard. a) genitalia del macho en vista ventral, b) aedeagus en vista lateral, c) genitalia de la hembra en vista ventral, d) venación alar del macho, y e) pata metatorácica. Escala genitalia $0,5 \mathrm{~mm}$, Escala alas $1 \mathrm{~cm}$.

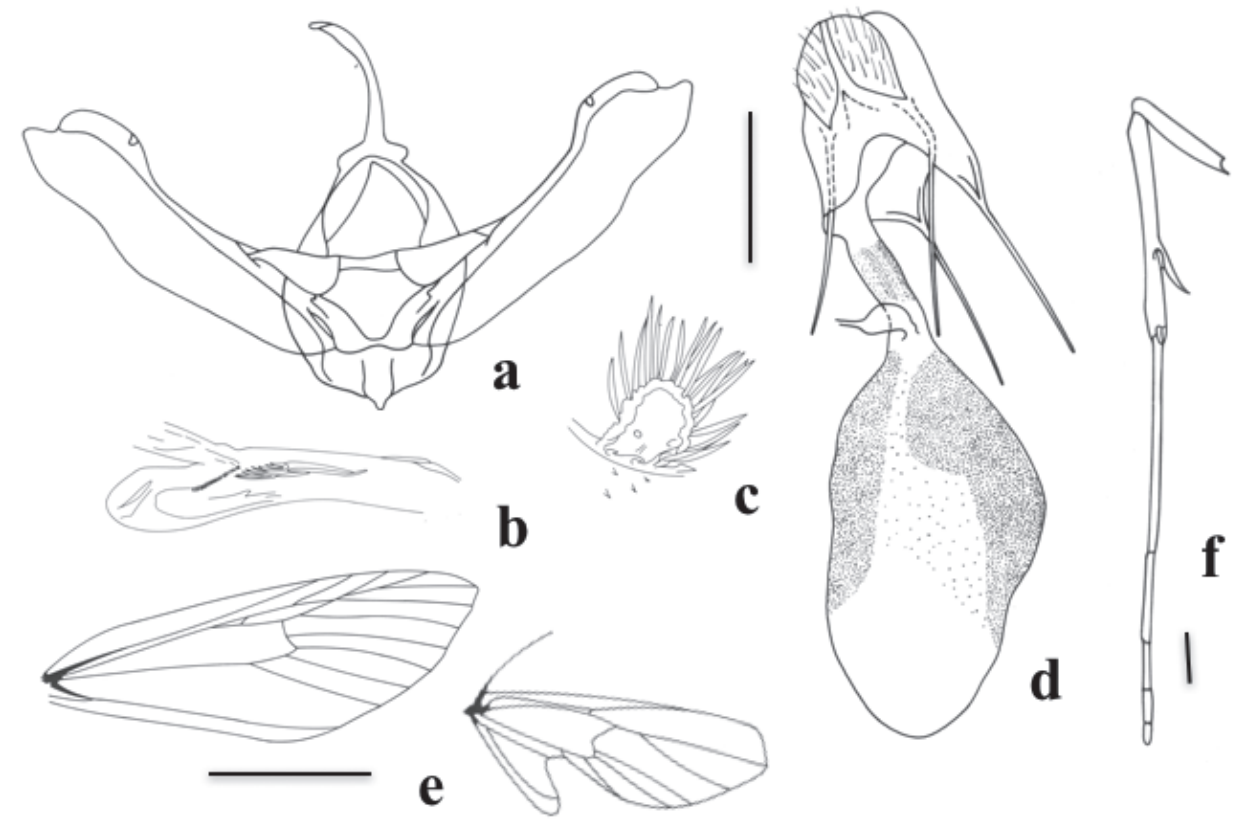

FIGURE 16. Genitalia and wing venation of Parapachrophylla michelleae Parra sp. n. a) male genitalia in ventral view, b) aedeagus in lateral view, c) detail of palpebriform appendix, d) female genitalia en ventral view, e and f) wing venation and metathoracic leg of $P$. claudiae Parra. Genitalia scale $0.5 \mathrm{~mm}$, Wing scale $1 \mathrm{~cm}$, Leg scale $0.5 \mathrm{~mm}$. / Armaduras genitales y venación alar de Parapachrophylla michelleae Parra sp. n. a) genitalia del macho en vista ventral, b) aedeagus en vista lateral, c) apéndice palpebriforme, d) genitalia de la hembra en vista ventral. e y f) venación alar del macho y pata metatorácica de $P$. claudiae Parra. Escala genitalia $0,5 \mathrm{~mm}$, Escala alas $1 \mathrm{~cm}$, Escala pata $0,5 \mathrm{~mm}$. 
subtriangular parts that diverge from their base; subtriangular saccus. Aedeagus sub equal along the valvae, vesica armed by a group of spines arranged in two rows, longer spines toward the distal region.

Female genitalia (Figs. 16d). Membranous, elongated corpus bursae, two times longer than its width and three times longer than the ductus bursae, with microspines in $2 / 3$ of the front of its internal wall which are not present in its ventral region; ductus bursae, 40 times longer than wide, colliculum (sclerotized area) occupies practically all its extension; posterior apophyses two times longer than the anterior.

Distribution. The records correspond to La Obra in the Metropolitan Region, La Mina and Los Queñes in the Maule Region, Chile.

Etymology: The species is dedicated to the first woman president of Chile, Michelle Bachelet Jeria.

SpeCies INCLUded

caliginosa Parra, 1991

claudiae Parra, 1991

michelleae Parra sp. nov.

Rindgenaria Parra, 1996

Rindgenaria Parra, 1996:43

Type species Ridgenaria multilineata Parra, 1996:44. By original designation.

\section{REDESCRIPTION}

The general appearance of the moth is shown in the figure 6e. Medium-sized moths, the forewing length varies between 14 and $16 \mathrm{~mm}$.

Ciliated antennae in the male, filiform in the female. Light brown forewings, lines perpendicularly crossed on their whole surface. White posterior wings. Forewing venation: with two accessory cells. Hindwing venation: Sc and Rs veins are anastomosed on the external third of the cell; Rs and $\mathrm{M}_{1}$ come from the same point, in the male with a lobe that has three anal veins (Fig. 17d); in the female with two anal veins. Legs: tibial formula $0-2-4$; male metathoracic tibia with hair pencil. Male abdomen with a sternal pouch.

Male genitalia (Figs. 17 a-b). Uncus thick with a slightly curved acute apex that reaches $1 / 3$ of the length of the valvae; subrectangular valvae, with a small triangular shaped indention in the third distal, that is projected towards the external side; anellus small, like a small thin layer; saccusvinculum subtriangular, globous. Aedeagus sub equal along the valvae, vesica armed with a group of small spines.

Female genitalia (Fig. 17c). Bursa copulatrix sub cylindrical; corpus bursae membranous with a small group of microspines in its mid-dorsal region; ductus bursae sclerotized in the cestum region, membranous in the colliculum; seminal duct and ductus bursae meet in a pyramidal protuberance; posterior apophyses two times longer than the anterior.

\section{DiFFERENTIAL DIAGNOSIS}

One of the characters that allows us to easily separate this genera from the others, is the presence of a third anal vein $\left(A_{1}\right)$ not stalked to $A_{2}$. The genitalia also have a distinctive pattern: in the male, the terminal portion of the valvae is rotated $90^{\circ}$ towards the ventral region (autoapomorphy). In the female, the characteristics are: corpus bursae form, an extended sac not observed in other genera; sclerotized cestum in the ductus bursae; and the membranous sac that exists in the seminal duct's place of insertion.

DisTRIBUTION

This endemic species is distributed only in the biogeographic provinces of the Northern Valdivian Forest, its most Northern record is Concepción $\left(36^{\circ} 30^{\prime} \mathrm{S}\right)$ and the most Southern is the Araucanía Region.

\section{OBSERVATIONS}

This genus forms a monophyletic group together with Tomopteryx + Triptila + Triptiloides for the presence of three anal veins on the male's hindwings (synapomorphy). However, the difference is: $A_{1}$ not stalked to $A_{2}$ and the apex's valvae are rotated towards the ventral region.

SPECIES INCLUded multilineata Parra, 1996

Tomopteryx Philippi, 1873

Tomopteryx Philippi, 1873:313

Type Species Tomopteryx amoena Philippi, 1873:313. Designated by Butler, 1882:396.

\section{REDESCRIPTION}

The general appearance of the moth is shown in the figure 6f. The length of the forewing varies between 14 and $17 \mathrm{~mm}$. Head without ocelli; chaetosomata present; filiform antennae slightly thickened in two thirds of the proximal (rhopalocerous-like). Anterior wings: $2 / 3$ of the basales dark and a third of the distal light. Posterior wings: light brown to ashy gray; the male has an anal lobe and an indention between the $\mathrm{Cu}_{1}$ and $\mathrm{Cu}_{2}$ veins. Forewing venation: with two accessory cells. Hindwing venation: Sc and Rs veins are parallel, they tend to come together at the mid-region of the distal cell, anastomosed in the female; Rs and $M_{1}$ are pedunculated in the male and female; lobe with two anal veins (Fig. 18d), the $A_{1}$ vein is pedunculated to $A_{2}$ and converges with $\mathrm{Cu}_{2}$. Legs: tibial formula 0-2-4; the femur 
has a tuft of hair on the inner leg and the male's metathoracic tibia has hair pencil. The abdomen has a sternal pouch.

Male genitalia (Figs. 18 a-b). Uncus thick, depressed, and pointed at the tip, three times smaller than the valvae; absent socius and gnathos; valvae 3 times longer than wide, deeply rooted on the ventral region; sacculus normal; anellus and saccus-vinculum subquadrangulars. Aedeagus subequal along the valvae, 10 times longer than wide; seminal duct comes from the sub anterior region of the sheath; bare vesica Female genitalia (Fig. 18c). Corpus bursae ovoid, membranous; ductus bursae halfway along the corpus bursae, 4 times longer than wide; cestum occupies $1 / 3$ of the length of the ductus; colliculum membranous. Posterior apophyses 1.25 times longer than the anterior.

\section{DiFFERENTIAL DIAGNOSIS}

This genus differs from others in the tribe because the $\mathrm{Cu}_{2}$ vein in the posterior wings extends to a small lobe; the anal lobe is wide, subtriangular, halfway along the wing, with two anal veins, $A_{2}$ on the wing lobe joint and $A_{3}$ on its interior (Fig. 18d).

The autoapomorphy that defines this genus is the ventral position of the valve's indention on the cucullus region.

\section{DisTRIBUTION}

Endemic species to Chile. It is distributed in the following biogeographic provinces: Coquimbo Desert, Central Valley, Northern Valdivian Forest and Valdivian Forest; it most Northern record is Principal, Santiago (33 $30^{\prime} \mathrm{S}$ ) and the most Southern is Valdivia $\left(40^{\circ} \mathrm{S}\right)$. The species has a distribution that coincides with schlerophyllus and temperate Chilean forests.

\section{OBSERVATIONS}

This genus together with Triptila and Triptiloides has pedunculated $A_{1}$ and $A_{2}$ veins in the male's posterior wing. The sister genus is Triptila because of the presence of an indention between the $\mathrm{Cu}$ veins in the male's posterior wing. Phillipi (1873) included three species in this genus, two of which differ from the type of species designated by Butler (1882) and have been considered here as two different genera: Triptila Warren, 1894 and Triptiloides Parra and Santos-Salas 1992a (see descriptions bellow).

\section{SPECIES InCluded}

amoena Philippi, 1873

ternata Felder y Rogenhofer, 1875 (Alsophila) jacintaria Staudinger, 1899 (Lobophora?)
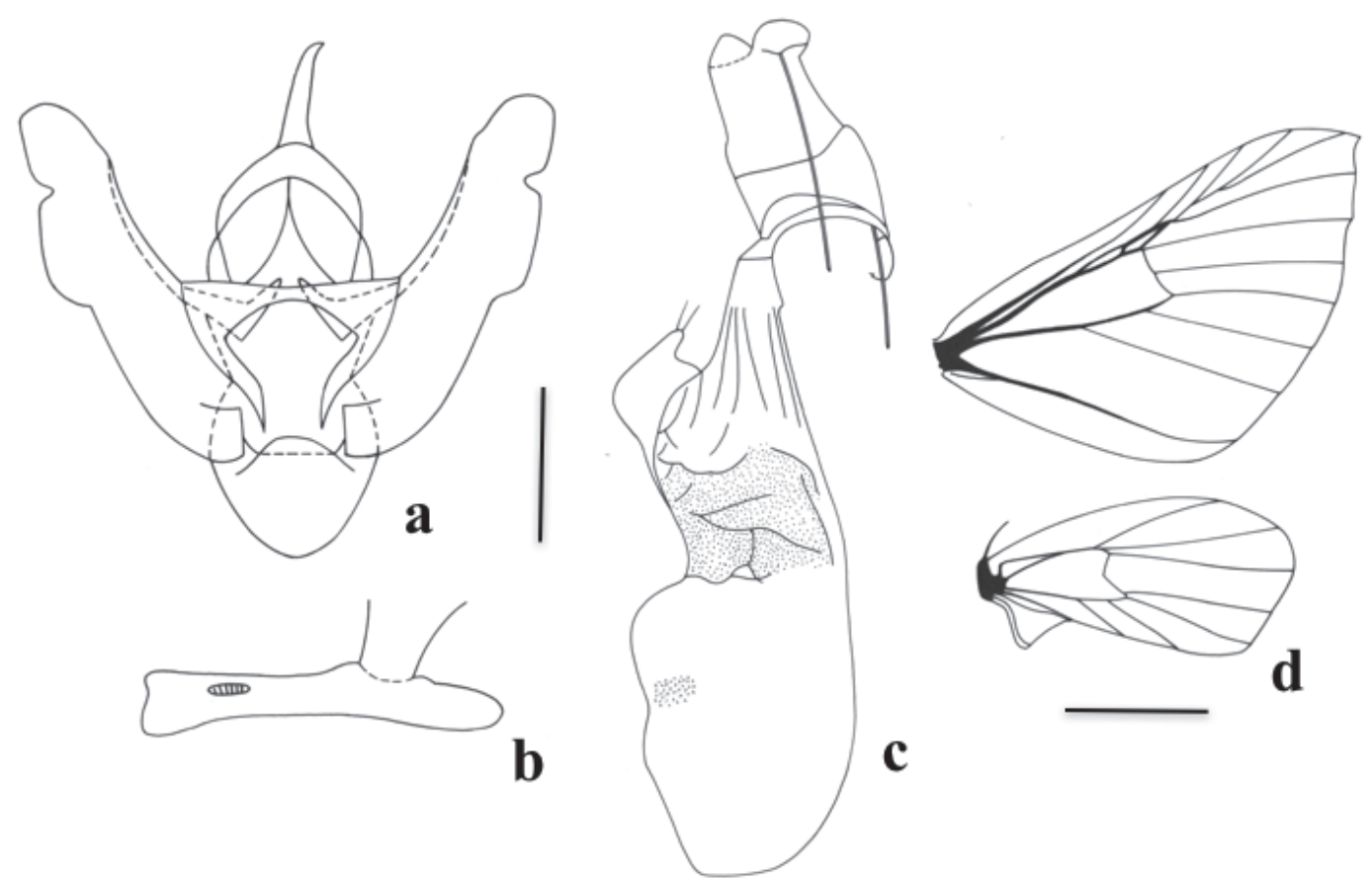

FIGURE 17. Genitalia and wing venation of Rindgenaria multilineata Parra. a) male genitalia in ventral view, b) aedeagus in lateral view, c) female genitalia in ventral view, and d) male wing venation. Genitalia scale $0.5 \mathrm{~mm}$, Wing scale $1 \mathrm{~cm}$. / Armaduras genitales y venación alar de Rindgenaria multilineata Parra. a) genitalia del macho en vista ventral, b) aedeagus en vista lateral, c) genitalia de la hembra en vista ventral, y d) venación alar del macho. Escala genitalia $0,5 \mathrm{~mm}$, Escala alas $1 \mathrm{~cm}$. 

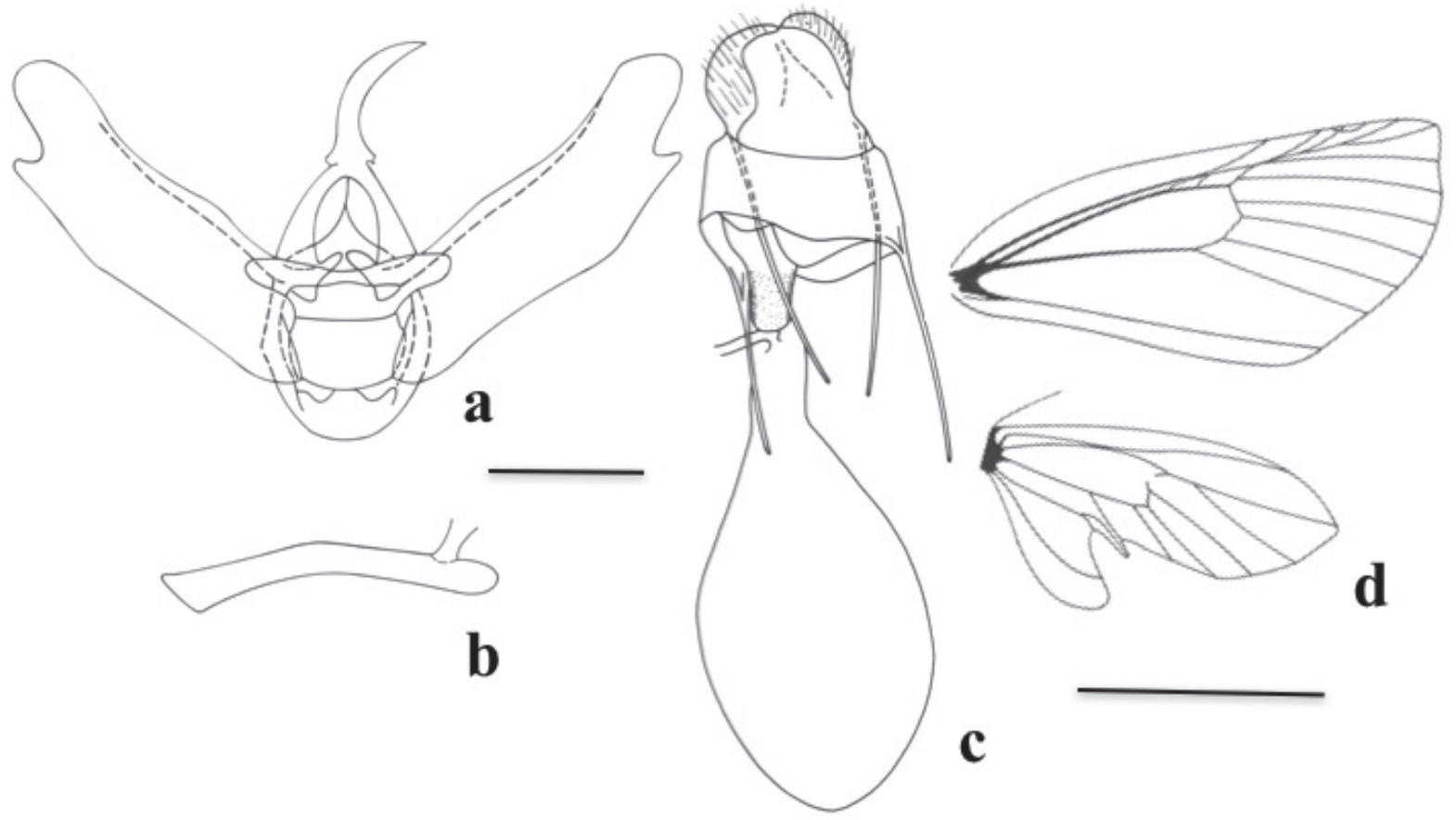

Figure 18. Genitalia and wing venation of Tomopteryx amoena Philippi. a) male genitalia in ventral view, b) aedeagus in lateral view, c) female genitalia in ventral view, and d) male wing venation. Genitalia scale $0.5 \mathrm{~mm}$, Wing scale $1 \mathrm{~cm}$. / Armaduras genitales y venación alar de Tomopteryx amoena Philippi. a) genitalia del macho en vista ventral, b) aedeagus en vista lateral, c) genitalia de la hembra en vista ventral, y d) venación alar del macho. Escala genitalia $0,5 \mathrm{~mm}$, Escala alas $1 \mathrm{~cm}$.
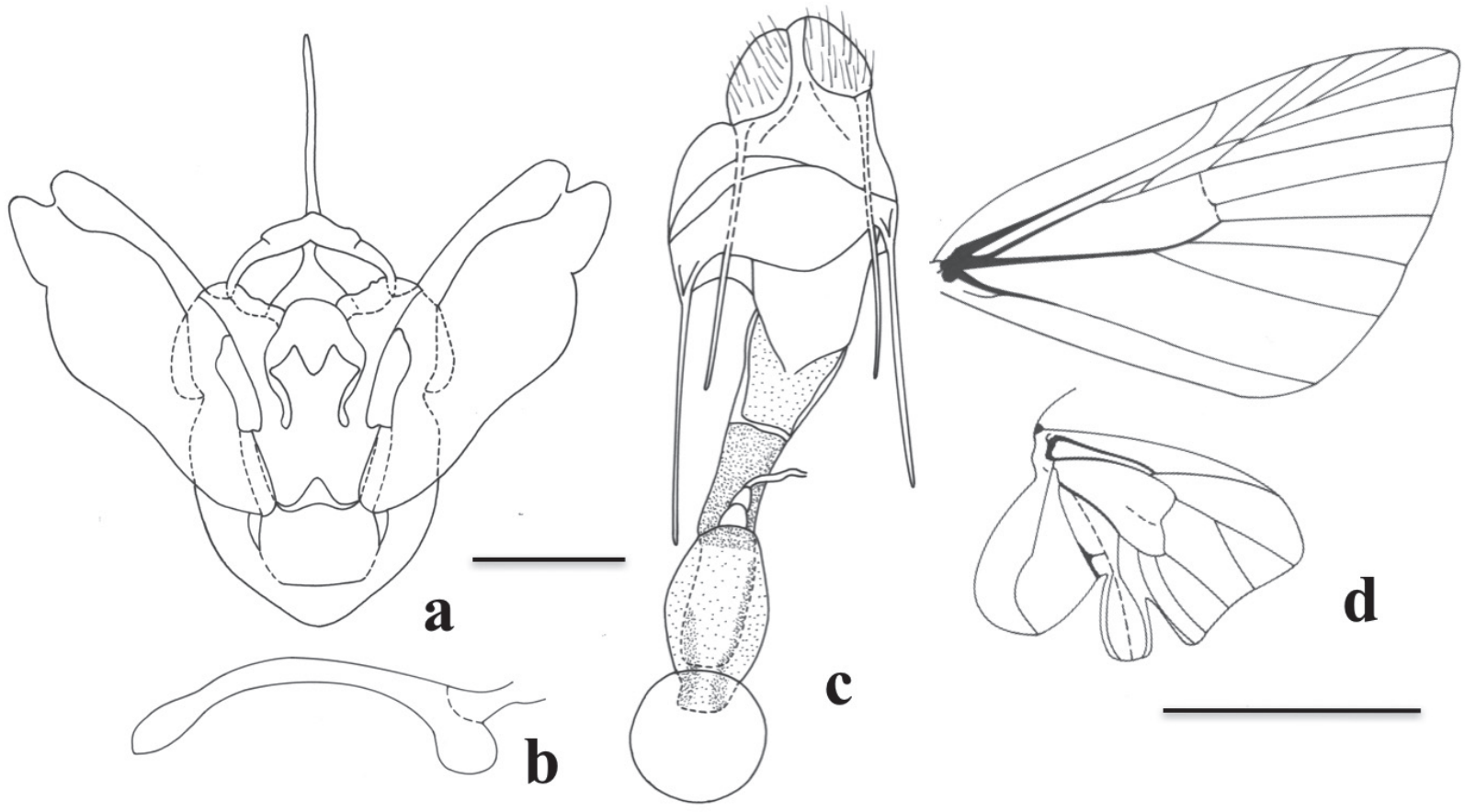

Figure 19. Genitalia and wing venation of Triptila virescens (Philippi). a) male genitalia in ventral view, b) aedeagus in lateral view, c) female genitalia in ventral view, and d) male wing venation. Genitalia scale $0.5 \mathrm{~mm}$, Wing scale $1 \mathrm{~cm}$. / Armaduras genitales y venación alar de Triptila virescens (Philippi). a) genitalia del macho en vista ventral, b) aedeagus en vista lateral, c) genitalia de la hembra en vista ventral, y d) venación alar del macho. Escala genitalia $0,5 \mathrm{~mm}$, Escala alas $1 \mathrm{~cm}$. 
Triptila Warren, 1894

Triptila Warren, 1894:398.

Type Species Tomopteryx virescens Philippi, 1873:315. Designated by Warren, 1894:398.

\section{REDESCRIPTION}

The general description of the moths is shown in the figures $6 \mathrm{~g}$ and $\mathrm{h}$. Medium to big moths, the length of the forewing varies between 16 and $23 \mathrm{~mm}$.

Head without ocelli; chaetosomata present; mid-segment of labial palpate, 4 times longer than the proximal and distal. Anterior wings light brown, green, or mottled with black and green spots. The hindwings are light brown or grayish; with two lobes, one in the anal region and another in the cubital vein zone. Forewing venation: two accessory cells. Hindwing venation: Sc and Rs veins are united by a transversal vein $1 / 3$ before the distal cell ends; the Rs andM, veins are pedunculated; anal and cubital lobes with two of each veins $\left(\mathrm{A}_{1+2}\right.$ and $\mathrm{A}_{3}$; veins $\mathrm{Cu}_{1}$ and $\mathrm{Cu}_{2}$ respectively) (Fig. 19d). Legs: tibial formula 0-2-4; male metathoracic tibia with a tuft of scales and hair pencil, respectively. Male abdomen with a sternal pouch (Fig. 2a), and bristled ventrals on the last abdominal segment (Fig. 2c).

Male genitalia (Figs. 19 a-b). Uncus thin and small, big and wide valvae with a small apical indention. The aedeagus is ventrally curved and the vesica is unarmed.

Female genitalia (Fig. 19c). Anterior part of the corpus bursae reduced, cylindrical, membranous posterior region, being similar in diameter to the ductus bursae; the ductus bursae is strongly sclerotized.

\section{DifFERENTIAL DIAGNOSIS}

This genus is distinguished from all the others in the tribe for the following characteristics: moths with large forewings, small hindwings ones, they are animals with green or brown colored wings with two lobes on the internal margin of the male's hindwings (anal and cubital) and a line of bristles on the posterior margin in the ventral area of the eighth abdominal segment (autoapomorphy). Male genitalia, ventrally curved aedeagus (autoapomorphy), saccus vinculum very developed. Female genitalia, corpus bursae membranous, reduced anterior part (autoapomorphy).

\section{DisTRIBUTION}

Endemic genus from Chile, its species live in the following biogeographic provinces: Coquimbo Desert, Central Valley, Southern Andean Mountain Range, Northern Valdivian Forest, Pehuenar, Valdivian Forest, and Aysén Mountain Range. T. virescens has a relatively wide distribution; in contrast, it is much reduced in T. ibarrai and $T$. septentrionalis.

\section{OBSERVATIONS}

This genus was created by Warren (1894) to distinguish the species, $T$. virescens from the genus Tomopteryx, in which Phillipi has initially categorized it. Warren says that Triptila and Tomopteryx are distinguished by the absence of an indention on the male's posterior wings. Parra and SantosSalas' (1992) show the differences that are found principally at the level of the genitalia and that the wings' nature and composition has a certain similarity in both genera. In the case of Tomopteryx, the indention between the $\mathrm{Cu}_{1}$ and $\mathrm{Cu}_{2}$ veins is not very developed; on the other hand, in Triptila it is obvious and makes it easier to distinguish the cubital lobe of the.

SPeCies InCluded ibarrai Parra \& Santos-Salas, 1992 perornata (Mabille, 1885) (Cidaria) septentrionalis Parra \& Santos-Salas, 1992 virescens (Philippi, 1873) (Tomopteryx)

\section{Triptiloides Parra \& Santos-Salas, 1992}

Triptiloides Parra \& Santos-Salas, 1992a:286.

TyPe SPeCIes Tomopteryx laeta Philippi, 1873:314. By original designation Parra \& Santos-Salas, 1992a:286.

\section{REDESCRIPTION}

The general description of the moths is shown in the figures 7 a-e. They are shown by size: small to big moths. The length of the anterior wing varies between 13 and $28 \mathrm{~mm}$.

Head without ocelli, chaetosomata present; antennae rhopalocerous like, thick with an acute end; palpo labial segment four times longer than the distal. Forewings variable in color and maculation, light brown, gray, or greenishbrown; bands present. Hindwings light brown, reddish brown or white; in the male with a lobe on the anal region and an indention between veins $\mathrm{Cu}_{1}$ and $\mathrm{Cu}_{2}$ and $\mathrm{Cu}_{2}$ and $\mathrm{A}_{1}$. Forewing venation: with two accessory cells. Hindwing venation: Sc and Rs united by a transversal vein $1 / 3$ before the end of the discal cell (Figs. 20 d-e); in the females, these veins are anastomosed (Fig. 20f); Rs and $\mathrm{M}_{1}$ are pedunculated or free. Legs: tibial formula 0-2-4; male's metathoracic tibia with hair pencil. Male's abdomen with sternal pouch.

Male genitalia (Figs. 20 a-b). Uncus simple; gnathos absent; socius reduced or absent; simple valvae, with an indention in the cucullus region; anellus simple, normally with a pair of projections on the mid-posterior region; aedeagus unarmed or armed

Female genitalia (Fig. 20c). Globous or elongated corpus bursae, membranous, sometimes with a belt of microspines on its posterior region; short ductus bursae, longer than wide; posterior apophyses two times longer than the anterior. 


\section{DifFERENTIAL DIAGNOSIS}

The diagnostic character to separate this genus from the others is that there is an indention on the wings between the $\mathrm{Cu}_{1}$ and $\mathrm{Cu}_{2}$ and $\mathrm{Cu}_{2}$ and $\mathrm{A}_{1}$, as well as a lobe with two anal veins.

The forewings can be as wide as in T. esmeralda or narrow like in T. laeta, because they are well resembled to those of the species Triptila or Pachrophylla. The genitalia are very different between the species that make up this genus.

\section{DisTRIBUTION}

Endemic genus to Chile, it is distributed in the following biogeographic provinces: Coquimbo Desert, Central Valley, Central Coastal Mountain Range, Southern Andes, Northern Valdivian Forest, Pehuenar, Valdivian Forest, and Magellanic Interoceanic. The most widely distributed species are T. fissa and T. griseofasciata.

\section{OBSERVATIONS}

This genus is fundamentally based on the venation of the lobe on the male's hindwings, despite the fact that the species that make it up show a pattern of non-homogenous genital armature. This is contrasted with the general tendency of the group, which is that within each genus, the male and female from different species maintain a consistent genital pattern. This fact is seen as much in the genera, Tatosoma, Sauris, Episteira, Tympanota from Oriental and Australian regions as in Fueguina, Butleriana, and Triptila from the Neotropical Region.

Species InCluded esmeralda (Bartlett-Calvert, 1893) (Rhopalodes)

fissa (Felder \& Rogenhofer, 1875) (Tomopteryx)

randallae (Sperry, 1951) comb. nov. (Spargania) griseofasciata Parra, 1996. syn. nov.

krahmeri Parra \& Santos-Salas, 1992

laeta (Philippi 1873) (Tomopteryx)

\section{Warrenaria Parra, 1991}

Warrenaria Parra, 1991:187.

Type Species Oporabia martha Butler, 1882:521. By original designation Parra, 1991:187.

\section{REDESCRIPTION}

The general appearance of the moth is shown in the figure $7 \mathrm{f}$. Medium sized moth, the anterior wing length is $16 \mathrm{~mm}$. Reddish head, without ocelli; chaetosomata present; reddish filiform antennae; reddish-brown thorax, abdomen, and legs. Forewings have medial and antemedial bands that are an intense reddish brown color; hindwings are reddish gray; the lobe overlaps the wings and reaches $1 / 3$ the length of the posterior wing. Forewing venation: with two accessory cells. Hindwing venation: Sc and Rs are united by a transversal vein at the end of the distal cell; Rs and $\mathrm{M}_{1}$ are sessile; lobe with two anal veins (Fig. 21c). Legs: tibial formula 0-2-4; male's femur and metathoracic tibia with a tuft of scales and hair pencil, respectively. Male's abdomen with a sternal pouch.

Male genitalia (Figs. 21 a-b). Uncus strong and compressed, much wider in its fourth subterminal, smaller than the valve; gnathos absent; socius reduced; valvae 4 times longer than wide, apex with a shallow indention; sacculus normal; anellus subtriangular; saccus-vinculum triangular shaped. Aedeagus sub equal along the valvae; seminal duct emerges on a third anterior of the sheath; vesica armed with spines.

Female. Unknown.

\section{DifFERENTIAL DIAGNOSIS}

This genus is easily recognizable from the other members of the tribe, because this species is a reddish-brown color, as much on the forewings as on the body's surface and appendixes. Male genitalia have a simple valvae, completely rectangular; uncus with a depressed protuberance (rhomboid) close to the apex (autoapomorphy); aedeagus with two groups of spines on the vesica.

\section{Distribution}

Endemic genus from Chile, it is distributed in the following biogeographic provinces: Coquimbo Desert and Valdivian Forest; its most Northern record is Las Zorras, Valparaiso $\left(33^{\circ} \mathrm{S}\right)$ and the most Southern, Valdivia $\left(40^{\circ} \mathrm{S}\right)$. It is found between the $5^{\text {th }}$ and $10^{\text {th }}$ regions in Chile, from the intermediate desert (coastal region) to the Valdivian Forest in its central coastal region.

\section{Observations}

The genus is close to Butleriana because of its male genital structure. Despite that, its maculation pattern makes it externally similar to those from the group, Triptalia.

In 1882, Butler described the only species from this genus as Oporabia martha. Oporabia is a junior synonym of Epirrita from the Palearctic Region not belonging to the Trichopterygini tribe. The analysis of the specimens led Parra (1991) to propose this species as a new genus for the tribe, even though its external and internal appearance (male genitals) are closer to the genera indicated above.

These same characteristics present clear differences from this taxon in respect to the others, which permits it to be considered as a species belonging to a completely different genus.

Species InCluded martha (Butler, 1882) (Oporabia) 

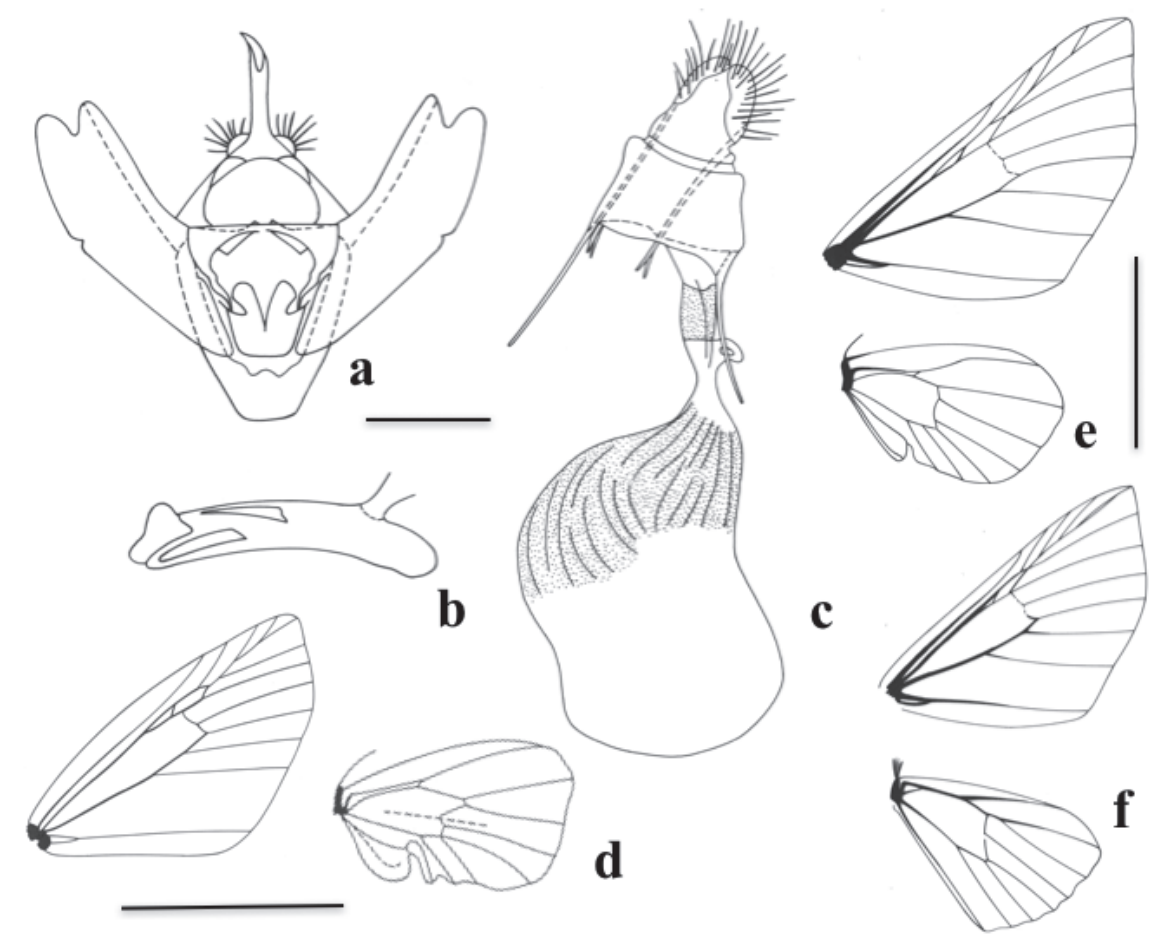

FiguRE 20. Genitalia and wing venation of Triptiloides. a) male genitalia in ventral view, b) aedeagus in lateral view, c) female genitalia in ventral view, and e and f) male wing venation of T. grisceofasciata Parra. d) male wing venation of T. esmeralda (Bartlett-Calvert). Genitalia scale $0.5 \mathrm{~mm}$, Wing scale $1 \mathrm{~cm}$. / Armaduras genitales y venación alar de Triptiloides. a) genitalia del macho en vista ventral, b) aedeagus en vista lateral, c) genitalia de la hembra en vista ventral, y e y f) venación alar del macho de T. grisceofasciata Parra. d) venación alar del macho de T. esmeralda (Bartlett-Calvert). Escala genitalia 0,5 mm, Escala alas $1 \mathrm{~cm}$.
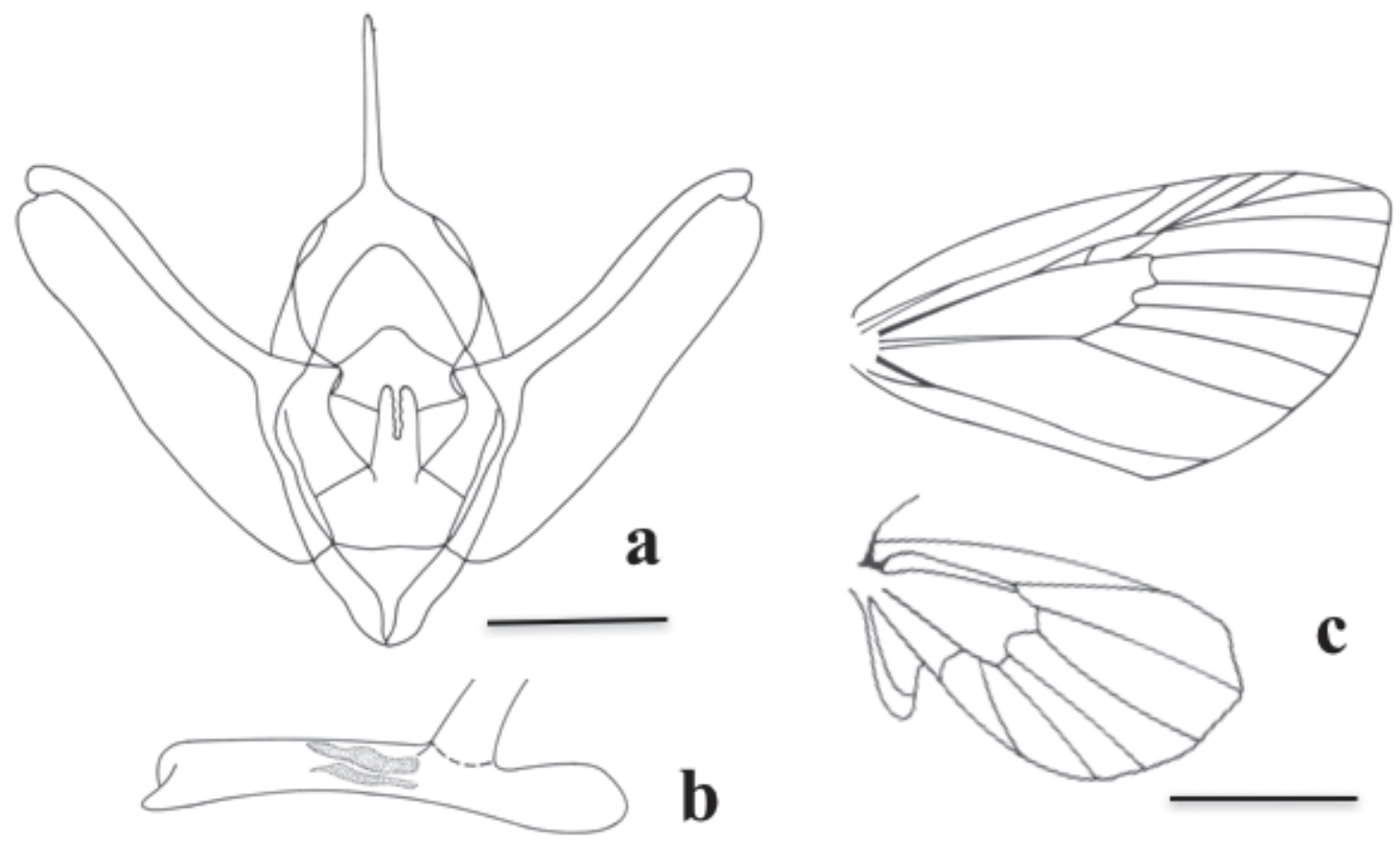

FIGURE 21. Genitalia and wing venation of Warrenaria martha (Butler). a) male genitalia in ventral view, b) aedeagus in lateral view, and c) male wing venation. Genitalia scale $0.5 \mathrm{~mm}$, Wing scale $1 \mathrm{~cm}$. / Armaduras genitales y venación alar de Warrenaria martha (Butler). a) genitalia del macho en vista ventral, b) aedeagus en vista lateral, y c) venación alar del macho. Escala genitalia 0,5 mm, Escala alas $1 \mathrm{~cm}$. 


\section{DISCUSSION}

The Trichopterygini genera studied form a homogeneous group, particularly easy to distinguish by the presence of a lobe, vesicle or flap in the hindwings of the male. Among the Larentiinae, the Trichopterygini tribe is recognized as one of the most ancient divergence groups alongside Chesiadini (Sihvonen et al. 2011, Ounap et al. 2016) although Õunap (pers. comm.) points out the most ancient should be Dyspteridini. These authors treated only the genera Tatosoma, Trichopteryx and Pterapherapteryx in their analysis, the South American genera were not included. Available information (morphological characters) indicates that the Neotropical genera are closely related to Tatosoma, the unique genus of New Zealand (Dugdale 1980).

Phylogenetic study shows that the group is monophyletic. Tatosoma shares many characteristics with the genera of the Andean Region and the monophyly of them is based on five synapomorphies, of which the swollen metaepimeron and sternal pouch that does not occlude the tympanic opening are the most important and strong. The other synapomorphic characters show a more ancient ancestral relationship with other genera distributed in the southern hemisphere. These relationships indicate that the genera of the southern hemisphere are related, and an analysis that includes all these will probably be necessary to improve our understanding of the group.

In general, the attempt to establish the synapomorphies that define the sister taxa revealed to be difficult using morphological characters. Only a more detailed analysis of other characters - as data from immature stages (larvae, pupae and eggs) and DNA - will allow a better resolution of the phylogeny of the group. Moreover, the geometrids associated with temperate forests of southern South America include many monotypic genera (Rindge 1983). Surely this condition is a sign of the presence of relict taxa that have retained much of the original characters (Davis 1986) and have followed a particular and independent specialization of other South American Trichopterygini, a condition that is favored by prolonged isolation of the southern forests, which has also impacted on the high frequency of families and monotypic genera of plants (Villagrán \& Hinojosa 1997).

Taxonomy. The Trichopterygini of Chile is a homogeneous group that is why various authors (Philippi 1873, Felder \& Rogenhofer 1875, Butler 1882, and BartlettCalvert 1893a and 1893b) included the different species in three genera originally: Pachrophylla, Tomopteryx and Rhopalodes. In several studies, analyzing characters of the hindwings and genitalia of males these genera were fractionated (Parra 1991, Parra \& Santos-Salas 1992a-b, Parra 1996).

The main changes with respect to the previous taxonomic order are: 1) the genus Lagynopteryx Berg is incorporated into the Trichopterygini; 2) Toxopaltes Warren is a junior synonym of Lagynopteryx; 3) Hoplosauris moesta is incorporated into the genus Llampidken; 4) Llampidken valdiviana is a junior synonym of L. moesta; 5) Oparabia arenosa is incorporated into the genus Arrayanaria; 6) Danielaparra viridis is a synonym of $D$. fragmentata; 7) Lobophora imbricaria is incorporated into the genus Danielaparra; 8) Triptiloides fasciata is a junior synonym of T. randallae; and 9) Parapachrophylla michelleae Parra n. sp. is described.

Trichopterygini Distribution. The Trichopterygini tribe has a worldwide distribution that includes all the faunistic regions, except for the West Pacific (Dugdale 1980).

The Trichopterygini species presented in this work are restricted to the South of Argentina and Chile, between $33^{\circ}$ and $55^{\circ} 31^{\prime} \mathrm{S}$. Members of the tribe have been collected in 11 biogeographic provinces, these are: Coquimbo Desert, Central Valley, Central Coastal Range, Southern Andes, Northern Valdivian Forest, Pehuenar, Valdivian Forest, Valdivian Range, Aysén Range, Magellanic Interoceanic, and Southern Pacific.

There are two distribution centers: the first is characterized by a temperate cold and humid climate whose vegetation is dominated by Nothofagus and associated vegetation, called Northern Valdivian Forest, Pehuenar, and the Valdivian Forest provinces. The other distribution area is made up of the Coquimbo Desert and Central Valley provinces, the climate here is dry to relatively dry with an annual precipitation of 350 (in the most Northern zone) to $1500 \mathrm{~mm}$ in the most southern part: the vegetation is dominated by sclerophyllous shrubbery and lowland forests (sclerophyllous forest and Roble-Hualo: Nothofagus obliqua, Acacia caven, Jubaea, chilensis, Lithrea causica, etc.). Many other species are found in both distribution centers, this is principally owed to the fact that the sclerophyllous and temperate forests are mixed especially between the Maule and Biobio rivers.

Lagynopteryx botulata is also distributed in Argentina, particularly in the biogeographic province, Valdivia Mountain Province. Probably other species distributed in that 'biotic province (shared by both countries) are present in Argentina. The genera Butleriana, Fueguina, Triptila, and Triptiloides have the widest distribution, Butleriana, Danielaparra and Fueguina reach the most southern distribution (Magellanic Interoceanic and Southern Pacific provinces).

Natural History of the Trichopterygini. Little is known about the history of the Trichopterygini from the studied region. The only known data from immature stages is that of Parapachrophylla claudiae Parra, 1991 (see Parra 1991). The larval host-plant of only two species is known: Parapacrophylla claudiae feeds on Discaria chacaye "Espino Blanco or chacay de la cordillera" (Rhamnaceae), the larvae develop between August and November (midwinter to mid-spring) and the pupation occurs in November; neither the egg development nor incubation period is known. 
Lagnopteryx botulata uses Maytenus boaria "Maitén" (Celastraceae) (Ibarra-Vidal com. pers.) as a larval hostplant. In both species, the adult emerges during the month of November.

The collection records show that Trichopterygini species are active during 11 months of the year. $B$. fasciata's imagos were collected in mid-July and late April, $F$. varians, $T$. krahmeri, and L. valdiviana have collection data until the end of April. This data plus that of the species' biology, indicated above, makes us assume that more than one generation is represented or that the pupa has a long period of diapause or that immature larvae go through this phase during winter, at least in the species mentioned above.

Obviously much of the knowledge of the natural history of South American Trichopterygini is still developing. However, this morphological phylogenetic study based on maximum parsimony and probabilities approximation (BMCMC) constitutes the necessary systematic basis on which other studies (e.g. biogeographic, ecological, physiological, evolutionary, etc.) can begin to be realized.

\section{ACKNOWLEDGMENTS}

We thank Mario Elgueta (MNHN) and Jorge N. Artigas (UCCC-MZUC) in Chile, and Adriana Chalup (IML) in Argentina, for their valuable cooperation obtaining literature for this study. We also thank M. J. Scoble and L. Pitkin $(\mathrm{BMNH})$ for their assistance during Parra's visit to The Natural History Museum. Isabel Head helped with English grammar. To Mario Ramos for the help with the photographs. This study was supported by the Research Division of the Universidad de Concepción (Grants 210.113.079-1.0 and 214.113.087-1.0, and the Scientific Instrumental Project 2001). Finally, the authors thank the reviewers for the valuable comments that substantially improved the final version of the manuscript.

\section{REFERENCES}

Angulo, A.O., Casanueva, M.E. 1981. Catálogo de los lepidópteros geométridos de Chile (Lepidoptera: Geometridae). Boletín de la Sociedad de Biología de Concepción, Chile 51:7-39.

Bartlett-Calvert, W. 1886. Catálogo de los lepidópteros Rhopaloceros y Heteroceros de Chile. Anales de la Universidad de Chile 69:313-352.

Bartlett-Calvert, W. 1890. Descripción de algunos nuevos lepidópteros de Chile. Imprenta Ercilla, Santiago de Chile, $16 \mathrm{pp}$.

Bartlett-Calvert, W. 1893a. Nuevos lepidópteros de Chile. Anales de la Universidad de Chile 84:813-834.

Bartlett-Calvert, W. 1893b. Descriptions of new species of Chilean Lepidoptera. Transactions of the Entomological Society of London 3:215-222.

Berg, C. 1883. Miscellanea lepidopterológica. Anales de la
Sociedad Científica Argentina 15:163-167.

Blanchard, E. 1852. Fauna Chilena. Insectos, Orden VI, Lepidópteros. In: Gay, C (Ed.). Historia Física y Política de Chile 7:1-112.

Bremer, K. 1994. Branch support and tree stability. Cladistics 40:295-304.

ButLer, A.G. 1882. Heterocerous Lepidoptera collected in Chili by Thomas Edmonds. Esq. Part III.-Geometrites. Transactions of the Entomological Society of London 3: 339-423.

Butler, A.G. 1893. On a small collection of Lepidoptera from Chili. The Annals and Magazine of Natural History, ser. 6 12:457-467.

Davis, D.R. 1986. A New Family of Monotrysian moths from Austral South America (Lepidoptera: Palaephatridae), with a phylogenetuc review of the Monotrysia. Smithsonian Contributions to Zoology 434:1-202.

Dognin, P. 1906. Heteroceres nouveaux de l' Amérique du Sud. Annales Societé Entomologique Belgique 50:204-214.

Dugdale, J.S. 1980. Australian Trichopterygini (Lepidoptera: Geometridae) with descriptions of Eight New Taxa. Australian Journal of Zoology 28:301-340.

Felder, C., Rogenhofer, A.F. 1875. Reise de österrreichischen Fregatte Novara um die Erde (Zoologischer Theil) Band 2(Abtheilung 2): pls. 121-140. Wien.

Felsenstein, J. 1985. ConWdence limits on phylogenies: An approach using the bootstrap. Evolution 39:783-791.

FLETCHER, D.S. 1953. Some new species of Geometridae from Argentina and Chile. Acta Zoologica Lilloana 12:367-380.

Fletcher, D.S. 1979. Geometroidea. In: The Generic Names of moth of the World (Ed. Nye, I.W.B.), 3:xx $+243 \mathrm{pp}$. Trustees of the British Museum (Natural History), London.

Forbes, W.T.M. 1948. Lepidoptera of New York and neighboring states. Part II. Memoir Cornell University Agricultural Experimental Station 274:1-263.

Hausmann, A., Viidalepp, J. 2012. Larentiinae I. The Geometrid Moths of Europe, Vol. 3, p. 743. Apollo Books, Vester Skerninge.

Herbulot, C. 1961-1963. Mise a jour de la liste des Geometridae des France. Alexanor, 2, 117-124, 147-154, 3, 17-24, 8593.

Holloway, J.D. 1997. The moths of Borneo, part 10: family Geometri- dae, subfamilies Sterrhinae and Larentiinae. Malayan Nature Journal 51:1-242.

HÜBNER, J. 1816 (1825). Verzeichniss bekannter Schmetterlinge (sic). Augsburg:431.

Huelsenbeck, J.P., Bollback, J.P. 2001. Empirical and hierarchical Bayesian estimation of ancestral states. Systematic Biology 50:351-366.

Kemal, M., KoçaK, A.Ö. 2004. Corrections and additions to the work entitled "Geometrid

Moths of the World”, edited by M.J. Scoble (Lepidoptera) - III. Centre for Entomological Studies, Miscellaneous Paper 90:1-5.

KLots, A.B. 1970. Lepidoptera. In: Tuxen, S.L. (Ed.) Taxonomist's glossary of genitalia in insects (second edition): 115-130. Munksgraard, Copenhagen, Denmark.

Leraut, P. 1980. Systematic and Synonymic List of the Lepidoptera of France, Belgium and Corsica. Supplement to Alexanor, Paris.

Mabille, M.P. 1885. Diagnoses de Lépidopteres nouveaux. 
Bulletin de la Societé Philomathique Paris 7(9):55-70.

McGuffin, W.C. 1958. Larvae of the Nearctic Larentiinae (Lepidoptera: Geometridae). The Canadian Entomologist Supplement 8:1-104.

Nixon, K.C. 2002. Winclada ver. 0.9.99.50.mexu (BETA). Published by the author, Ithaca, New York.

Õunap, E., Viidalepp, J., SaArma, U. 2008. Systematic position of Lythriini revised: transferred from Larentiinae to Sterrhinae (Lepidoptera, Geometridae). Zoologica Scripta 37:405-413.

Õunap, E., ViIdalepp, J., Truuverk, A. 2016. Phylogeny of the subfamily Larentiinae (Lepidoptera: Geometridae): integrating molecular data and traditional classifications. Systematic Entomology 41(4): 824-843.

ÖzDIKMEN, H. 2008. Replacement names for some preoccupied macro- and microlepidopteran genera (Lepidoptera). Munis Entomology \& Zoology Journal 3(1):185-190.

Pagel, M., Meade, A. 2004. A Phylogenetic Mixture Model for Detecting Pattern-Heterogeneity in Gene Sequence or Character-State Data. Systematic Biology 53:571-581.

PARra, L.E. 1991. Revisión y filogenia del género Pachrophylla Blanchard, 1852 (sensu auctorum) (Geometridae: Larentiinae: Trichopterygini). Gayana Zoología 55(2):145199.

PARRA, L.E. 1996. Trichopterygini Neotropicales IV: descripción de nuevos géneros y especies de Chile (Lepidoptera: Geometridae). SHILAP Revista de lepidopterología 24(93):37-54.

Parra, L.E., Jiménez-Urrutia, M.C., Zamora-Manzur, C. 2009. Revision of the genus Hoplosauris Butler 1882 (Lepidoptera: Geometridae). Zootaxa 1989:39-54.

Parra, L.E., Santos-Salas, C.P. 1992a. Trichopterygini Neotropicales II (Lepidoptera: Geometridae): el complejo Rhopalodes Guenée, 1857. Gayana Zoología 55(4):267303.

Parra, L.E., Santos-Salas, C.P. 1992b. Trichopterygini Neotropicales III: género y especie nuevos para Chile (Lepidoptera: Geometridae). Boletín de la Sociedad de Biología de Concepción 63:151-156.

Patocka, J. 1994. Die Puppen der Spanner Mitteleuropas (Lepidoptera, Geometridae): Charakteristik und bestimmungstabelle der Gattungen. Tijdschrift voor Entomologie 137:27-56.

PatockA, J. 1995. Die Puppen der Spanner Mitteleuropas, Unterfamilie Larentiinae, Tribus Lythriini, Xanthorhoini, Larentiini und Cidariini. Deutsche Entomologische Zeitschrift 42:139-174.

PhILIPPI, R.A. 1873. Chilenische Insekten. Stettiner Entomologische Zeitung 34:296-316.

Pierce, F.N. 1914. The genitalia of the Group Geometridea of the Lepidoptera of the British Islands. An account of the morphology of the male clasping organs and the corresponding organs of the female. Biddles Ltd., London. $84 \mathrm{pp}$.
Prout, L.B. 1912. The Palaearctic Geometrae. In: The Macrolepidoptera of the World (Ed. Seitz, A.). 4(1):181.

Prout, L.B. 1923. New Geometridae in the Tring Museum. Novitates Zoologicae 30:191-215.

RindGe, F.H. 1983. A generic revision of the new World Nacophorini (Lepidoptera, Geometridae). Bulletin of the American Museum of Natural History 175(2):147-262.

Scoble, M.J. 1995. The Lepidoptera. Form, Function and Diversity. The Natural Hisdtory Museum \& Oxford University Press, London. 404 pp.

Sihvonen, P., Mutanen, M., Kaila, L., Brehm, G., Hausmann, A., Staude, H.S. 2011. Comprehensive Molecular Sampling Yields a Robust Phylogeny for Geometrid Moths (Lepidoptera: Geometridae). PLoS ONE 6(6): e20356. doi:10.1371/journal.pone.0020356

Sorenson, M.D., Franzosa, E.A. 2007. TreeRot, version 3. Boston University, Boston, MA.

Sperry, J.L. 1951. Four South American Geometrid moths apparently undescribed. Bulletin of the Southern California Academy of Sciences 50(3):159-163.

Staudinger, O. 1898 (1899). Lepidopteren. Ergebnisse der Hamburger Magalhaensischen Sammelreise 4(7):1-103.

Strutzenberger, P., Brehm, G., Bodner, F., Fiedler, K. 2010. Molecular phylogeny of Eois (Lepidoptera, Geometridae): evolution of wing patterns and host plant use in a species rich group of Neotropical moths. Zoologica Scripta 39:603-620.

Swofford, D.L. 2002. PAUP* Beta Version. Phylogenetic Analysis Using Parsimony (*and other methods). Sunderland, MA, USA: Sinauer Associated.

VIIDALEPP, J. 2006. Cladistic analysis of the subfamily Larentiinae. pp. 202-203. In: Hausmann, A., McQuillan, P. (eds.) Proceedings of the Forum Herbulot 2006. Integration of molecular, ecological and morphological data: Recent progress towards the higher classi cation of the Geometridae (Hobart, 19-20 January 2006). Spixiana 29:199-216.

ViIDALEPP, J. 2011. A morphological review of tribes in Larentiinae (Lepidoptera: Geometridae). Zootaxa 3136:1-44.

Villagrán, C., Hinojosa, L.F. 1997. Historia de los bosques del sur de Sudamérica, II: análisis fitogeográfico. Revista Chilena de Historia Natural 70:225-239.

WARren, W. 1894. New genera and species of Geometridae. Novitates Zoologicae 1:366-466.

Warren, W. 1908. Descriptions of new species of South American Geometrid moths. Proceedings U.S. National Museum 34:91-110.

Yамамото, S., Sota, T. 2007. Phylogeny of the Geometridae and the evolution of winter moths inferred from a simultaneous analysis of mitochondrial and nuclear genes. Molecular Phylogenetics and Evolution 44:711-723. 


\section{APPENDIX 1}

\section{EXAMINED SPECIES AND PLACES CITED IN THE TEXT}

Arrayanaria duofasciata. CHILE: 1 male, HOLOTYPE, Arrayán, Santiago, 7-XII-1955; PARATYPE: 1 male, Arrayán, Santiago, 7-XII-1955; 1 male, Valdivia, I-1890 (UCCC-MZUC).

Arrayanaria santiaguensis. CHILE: 1 male, HOLOTYPE, Arrayán, Santiago, 6-XII-1955; 1 female, ALLOTYPE, Arrayán, Santiago, 5-XII-1955; PARATYPES: 1 male, Guayacán, 18XII-1943; 3 male, Valle Ramón, 11-XII-1955; 1 male, Arrayán, Santiago, 7-XII-1955; 1 female, Guayacán, 15-XII-1943, Dr. Peña; 1 female, Termas de Cauquenes, 11-I-1953 (MNHN).

Butleriana fasciata. CHILE: 1 female, HOLOTYPE, Las Zorras, Chili, T. Edmonds (BMNH); 1 male, Marga Marga, IX. 1927, Col. Ureta; Viña del Mar: 2 females, 11-IV-1953; 1 female, 15-IV-1953; 1 male, 11-VII-1953; 1 female, 15-VIII-1953; 1 female, 5-IX-1953 (MNHN). Citations. CHILE: Las Zorras, Valparaíso (Butler, 1882).

Butleriana fumosa. CHILE: 1 male, HOLOTYPE, Chili, T. Edmonds (BMNH); 1 female ALLOTYPE, Chili, T. Edmonds (BMNH); 1 male, Cautín, P.N. Villarrica, 7-I-1990, L.E. Parra col. (UCCC-MZUC); 1 female, Cautín, P.N. Villarrica, 7-I-1990, L.E. Parra col. (UCCC-MZUC).

Butleriana minor. CHILE: 1 male, HOLOTYPE, Chili, T. Edmonds; 1 female, ALLOTYPE, Chili, T. Edmonds (BMNH); 1 male, Col 22-2-60, T. Río Blanco, E. Krahmer (UCCC-MZUC); 1 male, Laguna Verde, 11-X-1936, Col. Ureta; 1 female, Viña del mar, 15-IV-1953; 1 female, Quellón, Chiloé, 21-II-1956, J. S. Vargas coll (MNHN).

Butleriana oculata. CHILE: 1 male, HOLOTYPE, Terre du Feu, Hyades \& Hann 1885, B. Orange, 29228.85 (MNHNP); 1 male, Isla Guarello, 4-III-87, López coll. (UCCC-MZUC). Citations. CHILE: Bahía Orange (Mabille, 1885).

Danielaparra fragmentata. CHILE: 1 male, HOLOTYPE, Quellón, Chiloé, 21-II-1956, J.S. Vargas col.; 1 female, ALOTYPE, Pemehue, 10-I-1956, R. Gutiérrez (MNHN); PARATYPES: 1 female, Quellón, Chiloé, 9-II-1956, J.S. Vargas; 1 female, Tres Puentes, Magallanes, X-1952, Rodríguez col.; 1 female, Cerro Castillo, Magallanes, I-1955, M. Cadoceo col. (MNHN); 1 male, Molina, 18-III-1943, Barros col.; 1 male, Volcán Chillán, 3-III1979; 3 females, Las Trancas, Cordillera de Chillán, 9-I-1996; 1 female, Contulmo, Palo Botado, 2-II-1953, L.E. Peña col.; 1 male, Lonquimay, 5-V-1950; Río Blanco, E. Krahmer coll.: 1 female, 19-II-1962, 1 male, 28-II-1962. 1 male, Valdivia, Dr, Reed col.; Maullín: 1 male, 14-XII-1942, 1 female, 1-I-1943, 1 female, 25I-1943. Maullín, S. Barros col.: 1 female II-1943, 1 female, 2-II1943, 1 female, III-1943. 1 male and 2 females, Tres Puentes, Magallanes, X-1952, Rodríguez col.; 1 female, Cerro Castillo, Magallanes, X-1952, Rodríguez col.; 1 female, Punta Arenas, Magallanes, 4-I-1952 (MZUC).

Fueguina celovalva. CHILE: 1 male, HOLOTYPE, Termas de Río Blanco, Cautín-II-51 (UCCC-MZUC). PARATYPES: 1 male, Termas de Río Blanco, Cautín, III-51; 1 male, Cautín, P. N. Villarrica, 7-I-1990, L. E. Parra (MZUC).
Fueguina magallanica. CHILE: 1 male, HOLOTYPE, Tres Puentes, X-1952, Rodríguez: Coll., Magallanes; PARATYPES: 1 male, Tres Puentes, X-1952, Rodríguez: Coll., Magallanes; 2 males, Pto. Natales, II-1955, Alarcón coll. (UCCC-MZUC).

Fueguina varians. CHILE: 1 male, HOLOTYPE, Chili, 82107, 1951-339; 1 female, ALLOTYPE, Chili, 82-107 (BMNH); 1 male, HOLOTYPE (L. stenopterata), Terre de Feu, Hyades \& Hahn 1885, 2927.85, B. Orange (MNHNP). 1 female, Viña del mar, 28-III-1953; 1 female, Termas de Cauquenes, 11-I-1953; Quellón: 1 male, 16-IV-1955, 2 males, 17-IV-1955, 1 male, 18-IV-1955, 1 male, 19-IV-1955. (MNHN). 1 female, Valdivia, 30-III-1960, E. Kramer; 1 female, Sto. Domingo, Prov. Valdivia, 19-III-1960, E. Krahmer; 1 male, Maullín, 9-II-1944 (MZUC). Citations. CHILE: Valdivia (Butler, 1882). Bahía Orange (Mabille, 1885).

Hoplosauris granitata. CHILE: HOLOTYPE: 1 male, Parque Nacional Lanín, Pucará, Argentina (IMLT). Melipilla. Curacaví: 1 female, 23-09-2000 Solervicens coll (UCCC-MZUC). Talca. Talca: 1 male, 14-08-1997 (UCCC-MZUC). Concepción. Concepción: 1 female, 07-10-1959; 1 female, 25-08-1960; 1 female, 23-091976 Ruiz coll. Chiguayante: 1 female, 03-08-1961; 1 female, 07-08-1961; 1 female, 13-08- 1961 (UCCC-MZUC). Malleco. Curacautín: 1 female, 26-08-1948 (UCCC-MZUC). Cautín. Jauja: 3 females, 23-08-1990 Carrasco coll; 2 males, 23-08-1990 Carrasco coll (UCCC-MZUC). Osorno. Osorno: 1 female, 10-101988 (UCCC-MZUC). Valdivia. Valdivia: 1 male, 07-09-1984; 3 females, 30-09-1987 (UCCC-MZUC).

Hoplosauris heliconoides. CHILE: 1 male, HOLOTYPE Baños de Chillán (BMNH); 1 female, Allotype, Corral, (BMNH). Cautín. Termas de río blanco; 1 female, 25-12-1960 Krahmer coll.; 1 male, 13-03- 1954 Wagenknecht coll (UCCC-MZUC).

Hoplosauris indistincta. CHILE: Valparaíso. SYNTYPE: 1 female, las Zorras, Chile (BMNH). Ñuble. Chillán: 1 female, 1710-1959 (UCCC-MZUC). Concepción. Concepción: 1 female, 0110-1959; 1 female, 03-10-1959; 1 female, 07-10-1959; 1 female 08-10-1961; 1 female, 11-12-1964; 1 female, 29-07- 1985 Carrasco coll; 1 female 07-08-1985 Carrasco coll. Chiguayante: 1 female, 29-10-1961; 1 female 30-10- 1961; 1 female, 12-11-1961 (UCCCMZUC). Malleco. Curacautín: 1 female, 07-10-1948 (UCCCMZUC). Valdivia. Valdivia: 3 females, 30-09-1987; 1 female 2110-1987 (UCCC-MZUC); 3 females, 30-04-1964 Wagenknecht coll; 1 female, 12-1964; Wagenknecht coll; 1 male, 30-04-1964; Wagenknecht coll; 1 male, 12- 1964 Wagenknecht coll (UMCE).

Hoplosauris mabillei. CHILE: Valparaíso. ALLOTYPE: 1 female Viña del Mar, Chile 23-7-1963. (UCCC-MZUC). Paratypes: Viña del Mar: 1 female, 23-07-1953; 1 female, 25-07-1953; 2 females, 1-08- 1953; 1 female, 8-8-1953; 2 females, 15-08-1953; 1 female 25-08-1953; 1 female 12-09-1953 (MZUC- UCCC). Santiago. Peñalolén: 1 female, 15-05-1953 (UCCC-MZUC). Ñuble. Quillón Cerro Negro: 1 female, 20-09-2003 Concha coll (UCCC-MZUC). Concepción. Concepción: 1 male, 5-10-1959; Chiguayante: 1 female, 07-08-1961 Hualpén: 1 female, 28-09-2001 Parra coll (UCCC-MZUC). Malleco. Curacautín: 1 male, 20-09-1948; 1 
female, 20-09-1948 (UCCC-MZUC). Osorno. Puerto Octay: 1 female, 15-07-1955 Oehrens coll; 1 female, 13-11-1955 Dehrens coll (UCCC-MZUC). Valdivia. Holotype: 1 male Valdivia, Chile 14-9-84 Beéche coll. (UCCC-MZUC). Valdivia: 1 female; 12 1964 Wagenknecht coll; 1 male, 30-04-1964 Wagenknecht coll; 1 male, 14-09-1984 Beeche coll; 1 macho, 23-09-1984 Beeche coll. Llanquihue. Maullín: 1 female, 10-11-1943 (UCCC-MZUC). Magallanes. Tres Puentes: 2 males, 02-1952 Rodríguez coll. (MZUC- UCCC).

Hoplosauris macarenae. CHILE: Valdivia. HOLOTYPE: 1 male Valdivia, Chile 14-09-84, Beéche coll (UCCC-MZUC). Allotype: 1 female Valdivia, Chile 10-64 Wagenknecht coll. (UMCE). Paratypes: Valdivia: 1 male, 1888 Paulsen coll (UCCCMZUC); 1 male, 01-1959 (UCCC-MZUC); 6 males, 30-04-1964 Wagenknecht coll; 3 females, 30-04-1964 Wagenknecht coll. (UMCE).

Hoplosauris pachrophylloides. CHILE: Ñuble. HOLOTYPE: 1 male Reserva Nacional Nuble 10-01-01, Ibarra Coll. Allotype: 1 female Reserva Nacional Ñuble, 10-01-01, Ibarra Coll (UCCCMZUC). Paratypes: Reserva Nacional Ñuble guardería los Peucos: 3 males, 10-01-2001 Ibarra coll; Las Trancas: 2 males, 11-011996; 1 male 16-01 1996. Volcán Chillán: 3 males, 1-03-1979; 3 females, 3-03-1979 (UCCC-MZUC). Cautín. Termas río blanco: 1 female, 15-03-1952 (UCCC-MZUC).

Hoplosauris schausi. CHILE: Ñuble. 1 male \& 1 female, without types, Chillán, Chile (USNM); Las Trancas: 1 female, 8-1-1996 Beéche coll; 4 males, 8-1-1996 Beéche coll; Bulnes km 25: 1 male 27-11-1981 (UCCC-MZUC); Concepción. Concepción: 1 female, 2-11-1960 Gramar coll; 1 female, 13-09- 2001 (UCCC-MZUC); Cautín. Termas río blanco: 1 male 3-1951 (UCCC-MZUC); Valdivia. Valdivia: 1 male, 22-1-1959 Krhamer coll; 1 male 6-21959 Krahmer coll. (UCCC-MZUC).

Hoplosauris valeria. CHILE: HOLOTYPE: 1 male Chile $(\mathrm{BMNH})$. Valdivia. Valdivia: 1 male, 5-11-

1958 Krhamer coll. 1 male, 01-08-1986 Krahmer coll. (UCCCMZUC); 3 males, 1-2008, Chile, Los Lagos, Huinay station (ZSM).

Llampidken moesta. CHILE: 1 male, HOLOTYPE, Prov. Valdivia, 7-IV-1961, E. Krahmer; 1 female, ALOTYPE, Prov. Valdivia, 6-III-1959 (UCCC-MZUC); 1 male, PARATYPE, Araucanía, II-12 (MNHN).

Pachrophylla linearía. CHILE: 1 female, HOLOTYPE, Chili, 1843, Gay, 15.43 (MNHNP); 1 male, HOLOTYPE (P. obelata), Chile (BMNH); Viña del mar: 1 female, I-1888, 1 female, 15-VIII1953, 5767, 1 female, 5-IX-1953, 1 female, Col. Paulsen (MNHN). 1 female, Verde, 10-X-1936, Coll. Ureta; 1 female, Represa, I.L. 1887, Col. Paulsen; 1 female, Valdivia, 2080 (MNHN). 1 female, Llolleo, 9-XII-1952; 1 female, Chiguayante, Manquimávida, 5-XII-1961, Hulot: Coll.; 1 male, Termas de Río Blanco, Cautín, III-57 (UCCC-MZUC). Citations. CHILE: Las Zorras, Valparaíso (Butler, 1882).

Parapachrophylla caliginosa. CHILE: 1 male, HOLOTYPE, la Obra, Santiago, XI-1951, n.n. coll. (UCCC-MZUC); 1 male, PARATYPE, Viña del Mar, 21-III-1953 (MNHN) Chile.
Parapachrophylla claudiae. CHILE: 1 male. HOLOTYPE, Nilahue, 5-I-1950 (MZUC); PARATYPES: 1 male, Guayacán, 16-X-1943, Dr. Peña, Coll. Ureta; 1 male, Col. Paulsen; Viña del Mar, I-1888, Col. Paulsen, 2074; 1 male, Viña del Mar, 11-VII1953; 1 male, Quillota, I-1888; 1 male, Laguna Verde, 10-X-1936, Coll. Paulsen; 1 male, (MNHN); 1 male, Las Trancas, Cordillera de Chillán, 11-I-1996, trampa coll.; 1 male, Nilahue, 5-I-1950 (UCCC-MZUC).

Rindgenaria multilineata. CHILE: 1 male, HOLOTYPE, Concepción, 18-XII-1961; 1 female, ALLOTYPE, Río Blanco, Malleco, III-1951, L.E. Peña col. (UCCC-MZUC); PARATYPES: 1 male, Araucanía; 1 male, XI-1887, Paulsen col. (MNHN).

Tomopteryx amoena. CHILE: 1 male, NEOTYPE (T. amoena), 105, 5417 (MNHN); 1 female, HOLOTYPE (A. ternata), Chile (BMNH); 1 male, Chile 6035; 1 male, Col. Paulsen, Chile, 6036; 1 male, SIN DATOS; 1 male, 105, Principal, II-1888; 1 female, Chile, 5418 (MNHN); 1 female, Concepción, 20-IX-1969, trampa: Coll.; 1 female, Valdivia, 16-II-1960, E. Krahmer (MZUC). Citations. CHILE: Valdivia (Philippi, 1873). Las Zorras, Valparaíso (Butler, 1882).

Triptila ibarrai. CHILE: 1 male, HOLOTYPE, Icalma, 22-I1990, Col. H. Ibarra (UCCC-MZUC).

Triptila septentrionalis. CHILE: 1 male, HOLOTYPE, El Canelo, 19-II-1933, Coll. Ureta, 5820; 1 female, ALLOTYPE, El Canelo, 16-II-1933, Coll. Ureta, 5822; PARATYPES: El Canelo: 1 female, 16-II-1933, 1 male, 19-II-1933, 5820, 1 male, 19-II1933, 5819, 1 male, 26-II-1933, 5821, 1 female, 26-II-1933, 5823 (MNHN).

Triptila virescens. CHILE: 1 male, HOLOTYPE, col. Paulsen, nro. 3834, Chile; 1 male S.I. 15/87, Paulsen col., 5754; 1 male, Quillota, I-1888, 5755; 1 female, Tirúa, 1-II-1952, col. G. Monsalve, 5757; 1 male, Caramavida, 5.10-II-1953, 1000 mts. Valdivia: 1 female, 1891, 5758, Paulsen col.; 1 male, 5756; 1 male, Dr. Reed, col. Ureta, 5753. Quellón, Chiloé, J.S. Vargas, coll.: 1 female, 7-II-1956, 1 female, I-1955, 1 male, I-1955; 1 female Coyhaique, I-1934 (MNHN). 1 male, Valdivia, 14-I-1959, E. Krahmer (BMNH). Valdivia, E. Krahmer coll.: 2 males, 7-I1959, 1 male, 22-X-1959, 1 male, 6-II-1959, 1 male, 15-I-1960; 1 male, 8-II-1960, 1 female, 16-II-1960, 1 male, 16-I-1959. 1 male, Prov. Valdivia, Sto. Domingo, Valdivia-Chile, 13-XII-1959, E. Krahmer; 1 male, 28-II-1962, T. Río Blanco, E. Krahmer (CK); 1 male, Dalcahue, Isla Chiloé (E), 10.12-XII-1954, col. L.E.Peña; 1 male, Chaitén, 3-II-1982, Cekalovic col.; 1 male, Nahuelbuta, Río Picayquen, 22-XII-1962, Fetis col.; 1 male, Caramavida, Nahuelbuta (W), (Arauco) 750 mts., 25.31-XII-1953, L.E.Peña col.; 1 male, Lonquimay, Cautín, II-1951; 1 female, Termas de Río Blanco, Cautín, III-1951; 1 male, Volcán Chillán, 3-III-1979; 1 male, Las Trancas, Cordillera de Chillán, 11-I-1996, Trampa col. (UCCC-MZUC). Citations. CHILE: Valdivia (Philippi, 1873).

Triptiloides esmeralda. CHILE: 1 female, NEOTYPE, Valdivia, I. Teja, 28-IX-1986, D. Jakson col. (UCCC-MZUC); 1 male, Quellón, 17-IV-1955, (MNHN). Puerto Octay, E. Oherens coll.: 1 male, 12-X-1955, 1 male, 18-X-1955, 1 female, 20-X-1955, 1 male, 27-X-1955, 1 female, 6-XI-1955, 1 female, 11-XI-1955, 
1 female, 13-XI-1955 (MNHN). Valdivia, Isla Teja, D. Jackson coll.: 1 female, 18-X-1986, 3 female, 24-X-1986, 1 female, 7-X1986 (UCCC-MZUC); 1 female, Valdivia, Nanguilan, 6-IV-1956, A.W.H.; 1 female, NO DATA; 1 female, Río Blanco, Curacautín, 26-XII-1946, A. Wagenknecht (MNHN); 1 female, Prov. Valdivia, Sto. Domingo, Valdivia, 26-IV-1982, E. Krahmer col.; 4 females, 20-XI-1962, Llancahue, E. Krahmer coll (CK). Citations. CHILE: Valdivia (Bartlett-Calvert, 1893a y 1893b).

Triptiloides fissa. CHILE: 1 male, HOLOTYPE, Chile; 1 female, ALLOTYPE, Chile (BMNH); 1 male, Viña del Mar, 8-VIII1953, 5.772; 1 female, Chiguayante, Manquimávida, 25-X-1951, Hulot col. (BMNH). Viña del Mar: 1 female, 18-VII-1953, 5793, 1 male, 8-VIII-1953, 1 male, 15-VIII-1953, 5777, 1 female, 15VIII-1953, 5792, 1 male, 5-IX-1953, 5773, 1 female, 30-X-1953, 5790 (MNHN). 1 male, Alfalfan, XII-1888, Paulsen col., 5.778; 1 female, El Canelo, 5-XI-1949; 1 male, Guayacán, 23-X-1943, L.E. Peña col. Ureta; 1 female, Araucanía, II-88, col. Paulsen, 5791 (MNHN). El Canelo: 1 female, 5-XI-1949, 1 female, 5-XI-1959 (UCCC-MZUC). 1 male and 1 female, Guayacán, Santiago, XII50 (UCCC-MZUC). Concepción: 1 female, 7-XI-1959, 1 male, 13-II-1960, 1 female, 17-X-1960, 1 male, 21-XI-1960, 1 female, 22-XI-1960, 1 male, 7-XII-1960, 1 male, 10-XII-1960, 1 female, 25-I-1961, 1 female, 28-I-1961, 1 male, 7-XII-1961 (UCCCMZUC). Chiguayante, Manquimávida, Hulot coll.: 1 male, 26-X1961, 1 female, 14-VIII-1961 (UCCC-MZUC). 1 male, Cocalán, 9-I-1986, Parra col.; 1 male, Yepo, Linares, O. Barros, 12-X-1951; 1 male, Cobquecura, 12,29-I-1972, Ramírez col.; 1 male, Hualpén, 26-IX-1992, Trampa coll.; 1 male, Villa Sta. Julia, Bulnes, 24-III1971; 1 male, Bulnes, 16-I-1982; 1 male, Atacalco, Chillán, 28-XI1951, L.E.Peña col.; 2 females, Las Trancas, Cordillera de Chillán, 11-I-1996, Trampa coll.; 1 male and 1 female, Nahuelbuta, Río Picoyquén, 22-XII-1962, Fetis col. (UCCC-MZUC). Termas de Río Blanco, Cautín: 1 female, II-1951, 1 male, III-1951; 1 male, Curillinque, 16-X-1949 (UCCC-MZUC).

Triptiloides griseofasciata. CHILE: 1 male, HOLOTYPE, Guayacán, 23-X-1943, Dr. Peña; 1 female, ALLOTYPE, La Obra, Santiago, 25-X-1951, T. Ramir, col. (MNHN). PARATYPES: Guayacán, Dr. Peña coll.: 1 male, 16-X-1943, 1 male, 23-X-1943,
1 male and 1 female, 7-XI-1943 (MNHN). Arrayán, Santiago: 1 female, 5-XII-1955, 1 female, 6-XII-1955, 1 female, 7-XII-1955 (MNHN). 1 male, Quebrada Macul, 2-I-1954; 1 female, Valdivia (MNHN). Quellón, Chiloé, J.S. Vargas coll.: 1 female, 9-II-1956, 1 male, 21-II-1956, 1 male, 21-II-1956 (MNHN). 1 male, El Manzano, Santiago, 12-XI-1950; 1 female, Yepo, Linares, 12X-1951, O.Barros; 1 male, Concepción, 18-III-1961; 1 female, Nahuelbuta, Río Picoyquén, 22-XII-1962, Fetis col.; 1 female, Tres Puentes, Magallanes, X-1952, Rodríguez col. (UCCC-MZUC).

Triptiloides krahmeri. CHILE: 1 male, HOLOTYPE Valdivia, 15-I-1959, E. Krahmer col.; 1 female, ALLOTYPE, Valdivia, 15-III-1961, E. Krahmer col. (MNHN); PARATYPES: 1 male, Concepción, 11-IV-1961; 1 male, Pichinahuel, Nahuelbuta (Arauco), 13,31-I-1954, L.E. Peña col.; 2 males, Valdivia, 25III-1960, E. Krahmer col. (UCCC-MZUC); 1 male, Concepción, 30-III-1960 (BMNH). Valdivia, E. Krahmer coll.: 1 male, 28-III1960, 1 male, 30-III-1960; 1 male, 1990; 1 female, Araucanía, II1988 (MNHN).

Triptiloides laeta. CHILE: 1 male, NEOTYPE, Sto. Domingo, Prov. Valdivia, 8-XII-1982, E. Krahmer col. (MNHN); 1 male, Valdivia, 9-I-1959, E. Krahmer (BMNH). 1 male, Valdivia, 30XII-1958, E. Krahmer col. (MZUC); 1 male, Quellón, Chiloé, II-1955, Vargas col. (MNHN); Valdivia, Paulsen coll.: 1 male, 3 females, NO DATA (MNHN). Valdivia, E. Krahmer coll.: 4 males, 4-I-1959, 1 female, 16-I-1959, 1 female, 22-I-1959, 2 females, 11-I-1960 (CK). Valdivia, E. Krahmer coll.: 1 female, 11-I-1960, 1 male, 16-I-1959 (UCCC-MZUC). 1 male, Pemehue, I-1896, Paulsen col.; 1 male, Valdivia, 2122 (MNHN). 1 female, Purema, Concepción, 19-XII-1953, L.E. Peña col.; 2 females, Termas de Río Blanco, Cautín III-57; 1 female, Maullín, 12-II-1943; 1 male, Quemchi, Chiloé, II-1952, L.E.Peña col. (UCCC-MZUC). Citations. CHILE: Valdivia (Philippi, 1873).

Warrenaria martha. CHILE: 1 male, HOLOTYPE, Las Zorras, Chili (BMNH); Valdivia, E. Krahmer coll.: 1 male, Valdivia, 8-I1959, 1 male, 1-II-1959, (UCCC-MZUC). Citations. CHILE: Las Zorras, Valparaíso (Butler, 1882). 